\title{
Water Quality and Bed Sediment Quality in the Albemarle Sound, North Carolina, 2012-14
}

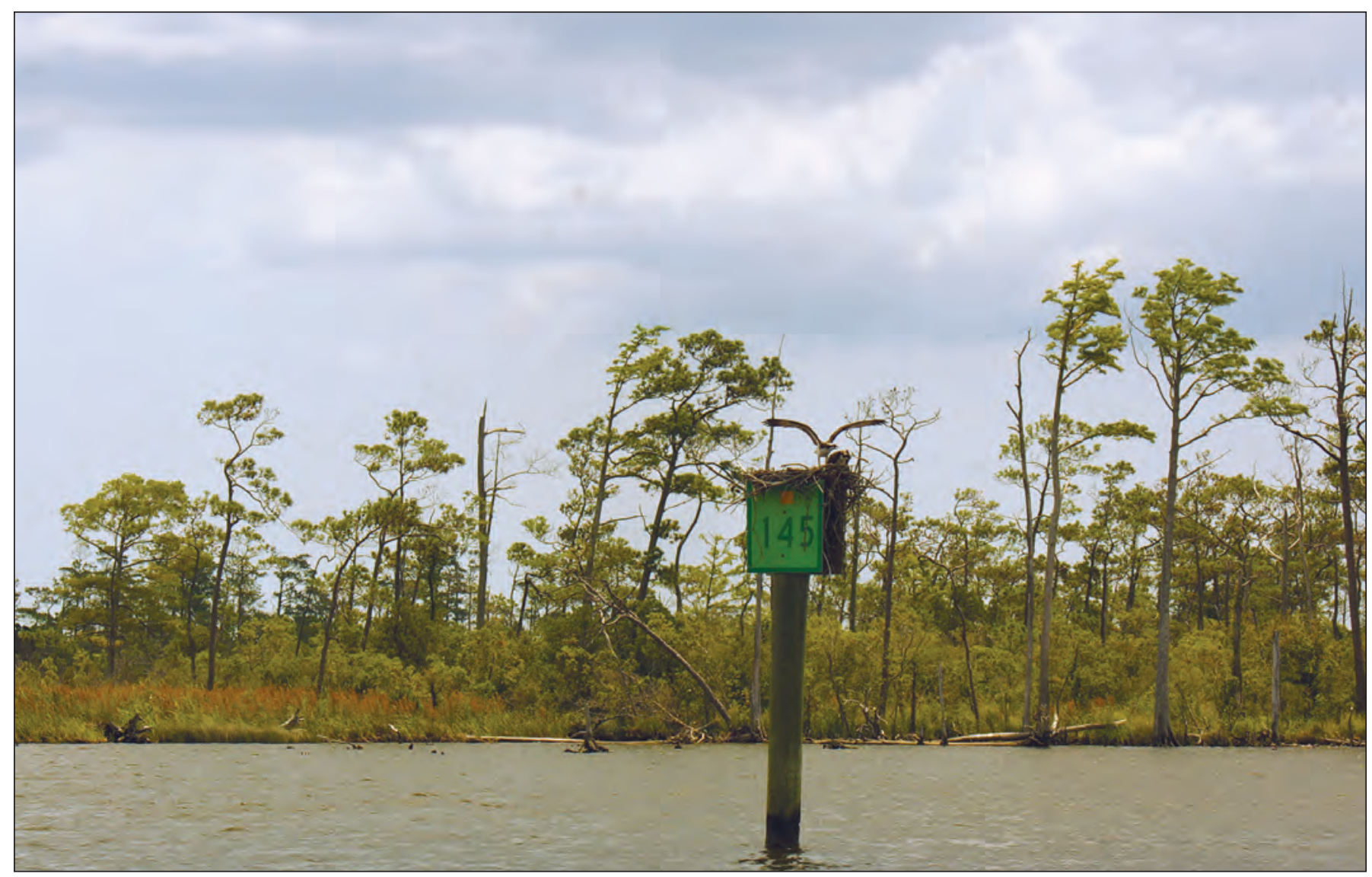

Open-File Report 2016-1171 
Cover. North River (Photograph by Michelle C. Moorman, USGS). 


\section{Water Quality and Bed Sediment Quality in the Albemarle Sound, North Carolina, 2012-14}

Michelle C. Moorman, Sharon A. Fitzgerald, Laura N. Gurley, Ahmed Rhoni-Aref, and Keith A. Loftin

Open-File Report 2016-1171 


\section{U.S. Department of the Interior SALLY JEWELL, Secretary}

\section{U.S. Geological Survey Suzette M. Kimball, Director}

\section{U.S. Geological Survey, Reston, Virginia: 2017}

For more information on the USGS - the Federal source for science about the Earth, its natural and living resources, natural hazards, and the environment—visit http://www.usgs.gov or call 1-888-ASK-USGS.

For an overview of USGS information products, including maps, imagery, and publications, visit http://store.usgs.gov/.

Any use of trade, firm, or product names is for descriptive purposes only and does not imply endorsement by the U.S. Government.

Although this information product, for the most part, is in the public domain, it also may contain copyrighted materials as noted in the text. Permission to reproduce copyrighted items must be secured from the copyright owner.

Suggested citation:

Moorman, M.C., Fitzgerald, S.A., Gurley, L.N., Rhoni-Aref, Ahmed, and Loftin, K.A., 2017, Water quality and bed sediment quality in the Albemarle Sound, North Carolina, 2012-14: U.S. Geological Survey Open-File Report 2016-1171, 46 p., https://doi.org/10.3133/ofr20161171.

ISSN 2331-1258 (online) 


\section{Contents}

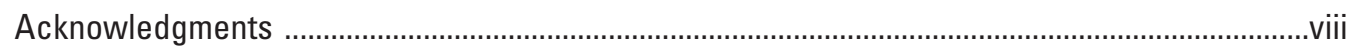

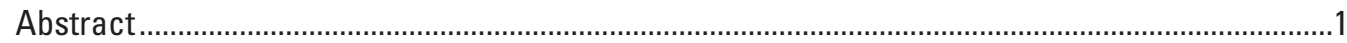

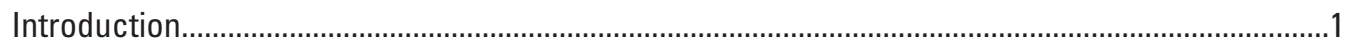

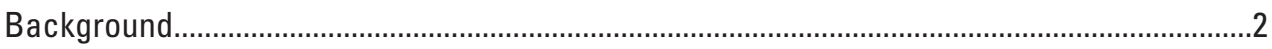

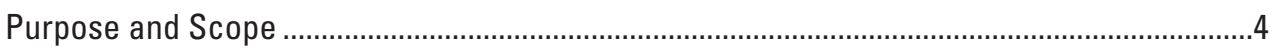

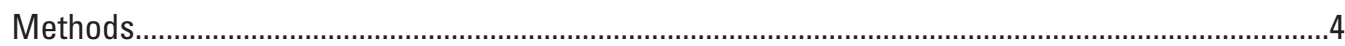

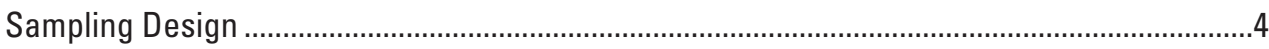

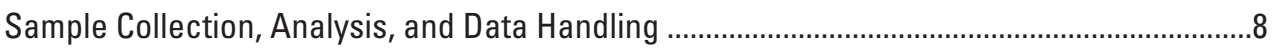

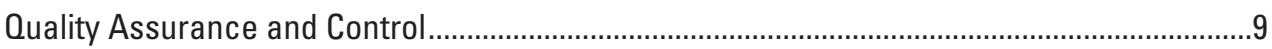

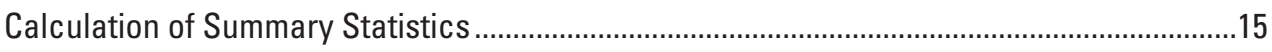

Occurrence and Distribution of Constituents in Water ..............................................................15

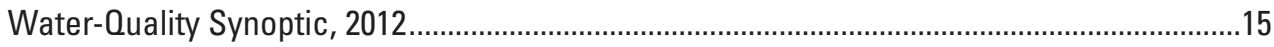

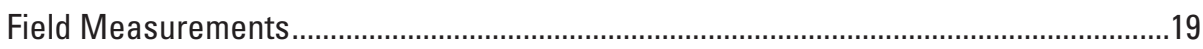

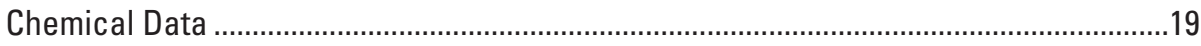

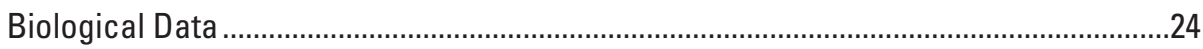

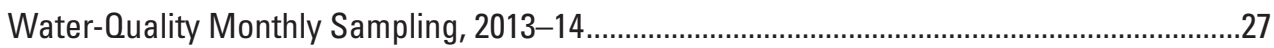

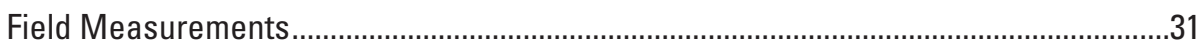

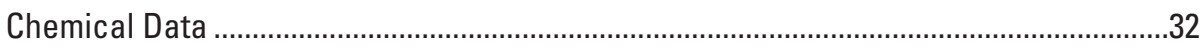

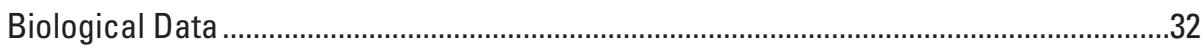

Occurrence and Distribution of Elements in Bed Sediment.............................................................35

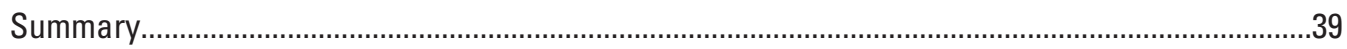

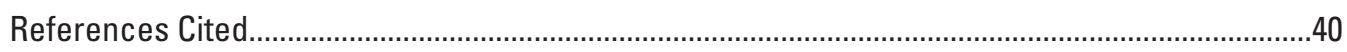

Appendix 1. Quality Control Results ......................................................................................4

Appendix 2. Chemical, Biological and Physical Results for Samples Collected in the Albemarle Sound and Tributaries, 2012 .......................................................................46

Appendix 3. Chemical, Biological and Physical Results for Samples Collected in the Albemarle Sound and Tributaries, 2013-14 ............................................................46

Appendix 4. Constituents in Bed Sediment Samples Collected in the Albemarle Sound

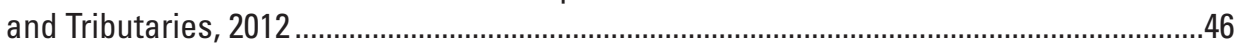




\section{Figures}

1. Map showing basins and subbasins in the Albemarle Sound study area... .3

2. Map showing sites sampled in the Albemarle Sound and tributaries, 2012-14

3. Graph showing properties of water samples collected in the Albemarle Sound and tributaries in 2012, grouped into three categories, with concentrations that were greater than a water-quality threshold.

4. Map showing distribution of salinity measured in the Albemarle Sound and tributaries, 2012

5. Map showing distribution of relative density differential calculated for sites in the Albemarle Sound and tributaries, 2012.

6. Map showing distribution of field pH values measured in the Albemarle Sound and tributaries, 2012

7. Map showing distribution of field transparency values measured in the Albemarle Sound and tributaries, 2012.

8. Map showing distribution of total nitrogen values measured in the Albemarle Sound and tributaries, 2012.

9. Map showing distribution of phosphorous values measured in Albemarle Sound and tributaries, 2012.

10. Map showing distribution of chlorophyll a values measured in the Albemarle Sound and tributaries, 2012

11. Graph showing total phytoplankton density and percent phytoplankton density by group for samples collected during summer 2012 in the Albemarle Sound and tributaries

12. Map showing distribution of cyanobacteria density measured in the Albemarle Sound and tributaries, 2012.

13. Graphs showing properties of water samples collected in the Albemarle Sound study area from March 2013 through February 2014, grouped into two categories, with concentrations that were greater than a water-quality threshold.

14. Graph showing calculated relative density differential for sites sampled in the Albemarle Sound study area from March 2013 through February 2014.

15. Graph showing seasonal concentration summaries of total nitrogen and phosphorus in the Albemarle Sound study area, 2013-14

16. Photographs of elevated levels of the cyanotoxin, microcystin, were measured at 68 parts per billion in a bloom dominated by Anabaena in the Chowan River on August 13, 2013

17. Graphs showing total phytoplankton density and percent phytoplankton density by group for samples collected during spring, summer, and fall 2013 at sites in the Albemarle Sound study area

18. Graph showing element concentrations in bed sediments from the Albemarle Sound and tributaries in 2012 that were greater than at least one bed sediment threshold

19. Maps showing properties of bed sediments from the Albemarle Sound and tributaries in 2012.

20. Graph showing relation between silt plus clay and total organic carbon in surficial bed sediments from the Albemarle Sound and tributaries, 2012. 


\section{Tables}

1. Description of data-collection sites in the Albemarle Sound and tributaries,

2012-14. .5

2. Analytical information for physical properties and chemical constituents measured in samples of water and bed sediments collected in the Albemarle Sound and tributaries, 2012-14...

3. Summary statistics for water-quality data collected in the Albemarle Sound and tributaries, 2012

4. Comparison of results to water-quality thresholds for samples collected in the Albemarle Sound and tributaries, 2012

5. Summary statistics for water-quality data collected in the Albemarle Sound and tributaries, March 2013 through February 2014

6. Comparison of results to water-quality thresholds for samples collected in the Albemarle Sound and tributaries, March 2013 through February 2014.

7. Summary statistics for bed-sediment quality data collected in the Albemarle Sound and tributaries, 2012...

8. Comparison of results to bed-sediment quality thresholds for samples collected in the Albemarle Sound and tributaries, 2012. 


\section{Conversion Factors}

International System of Units to Inch/Pound

\begin{tabular}{|c|c|c|}
\hline Multiply & By & To obtain \\
\hline \multicolumn{3}{|c|}{ Length } \\
\hline centimeter $(\mathrm{cm})$ & 0.3937 & inch (in.) \\
\hline millimeter (mm) & 0.03937 & inch (in.) \\
\hline meter $(\mathrm{m})$ & 3.281 & foot $(\mathrm{ft})$ \\
\hline kilometer (km) & 0.6214 & mile (mi) \\
\hline kilometer $(\mathrm{km})$ & 0.5400 & mile, nautical (nmi) \\
\hline meter $(\mathrm{m})$ & 1.094 & yard (yd) \\
\hline \multicolumn{3}{|c|}{ Area } \\
\hline square kilometer $\left(\mathrm{km}^{2}\right)$ & 247.1 & acre \\
\hline square kilometer $\left(\mathrm{km}^{2}\right)$ & 0.3861 & square mile $\left(\mathrm{mi}^{2}\right)$ \\
\hline \multicolumn{3}{|c|}{ Volume } \\
\hline milliliter $(\mathrm{mL})$ & 0.03381 & ounce, fluid (fl. oz) \\
\hline liter (L) & 33.82 & ounce, fluid (fl. oz) \\
\hline liter $(\mathrm{L})$ & 2.113 & pint (pt) \\
\hline liter (L) & 1.057 & quart (qt) \\
\hline liter (L) & 0.2642 & gallon (gal) \\
\hline cubic meter $\left(\mathrm{m}^{3}\right)$ & 264.2 & gallon (gal) \\
\hline cubic meter $\left(\mathrm{m}^{3}\right)$ & 0.0002642 & million gallons (Mgal) \\
\hline liter $(\mathrm{L})$ & 61.02 & cubic inch $\left(\mathrm{in}^{3}\right)$ \\
\hline cubic meter $\left(\mathrm{m}^{3}\right)$ & 35.31 & cubic foot $\left(\mathrm{ft}^{3}\right)$ \\
\hline cubic meter $\left(\mathrm{m}^{3}\right)$ & 1.308 & cubic yard $\left(\mathrm{yd}^{3}\right)$ \\
\hline cubic meter $\left(\mathrm{m}^{3}\right)$ & 0.0008107 & acre-foot (acre-ft) \\
\hline \multicolumn{3}{|c|}{ Flow rate } \\
\hline cubic meter per second $\left(\mathrm{m}^{3} / \mathrm{s}\right)$ & 35.31 & cubic foot per second $\left(\mathrm{ft}^{3} / \mathrm{s}\right)$ \\
\hline \multicolumn{3}{|c|}{ Mass } \\
\hline kilogram (kg) & 2.205 & pound avoirdupois (lb) \\
\hline
\end{tabular}

Temperature in degrees Celsius $\left({ }^{\circ} \mathrm{C}\right)$ may be converted to degrees Fahrenheit $\left({ }^{\circ} \mathrm{F}\right)$ as follows:

$$
{ }^{\circ} \mathrm{F}=\left(1.8 \times{ }^{\circ} \mathrm{C}\right)+32
$$

Temperature in degrees Fahrenheit $\left({ }^{\circ} \mathrm{F}\right)$ may be converted to degrees Celsius $\left({ }^{\circ} \mathrm{C}\right)$ as follows:

$$
{ }^{\circ} \mathrm{C}=\left({ }^{\circ} \mathrm{F}-32\right) / 1.8
$$




\section{Datum}

Horizontal coordinate information is referenced to the North American Datum of 1983 (NAD 83).

\section{Supplemental Information}

Concentrations of chemical constituents in water are given either in milligrams per liter (mg/L) or micrograms per liter ( $\mu \mathrm{g} / \mathrm{L})$.

Specific conductance is given in microsiemens per centimeter at 25 degrees Celsius $(\mu \mathrm{S} / \mathrm{cm}$ at $\left.25^{\circ} \mathrm{C}\right)$.

Total phytoplankton density is given in cells per milliliter (cells $/ \mathrm{mL}$ ).

The North Carolina Department of Environment and Natural Resources (NCDENR) was renamed the North Carolina Department of Environmental Quality (NCDEO) after the study but before the data were published.

\section{Abbreviations}

DWR Division of Water Resources

ELISA enzyme-linked immunosorbent assay

EPA U.S. Environmental Protection Agency

NCDENR North Carolina Department of Environment and Natural Resources

NMN National Monitoring Network

NWIS National Water Information System

PRISM Parameter-elevation Regressions on Independent Slopes Model

RDD relative density differential

ROS regression order on statistics

RPD relative percent difference

TN total nitrogen

USGS U.S. Geological Survey

WHO World Health Organization 


\section{Acknowledgments}

We would like to thank our partner agencies including the North Carolina Department of Environment and Natural Resources Division of Water Resources, the North Carolina Division of Marine Fisheries, the U.S. Army Corps of Engineers, the U.S. Fish and Wildlife Service, and the University of North Carolina Coastal Studies Institute for assistance with field and lab logistics. We thank Division of Water Resources employees Elizabeth Fensin for providing all the phytoplankton cell counts and biovolumes and Steve Kroeger for reviewing the manuscript.

We thank Alex Cordaro, Jessica Cain, Dominick Antolino, Katie Weaver, and Erik Staub of the U.S. Geological Survey South Atlantic Water Science Center for help with field sampling. Additionally, the authors thank J. Graham of the U.S. Geological Survey for reviewing the manuscript. 


\title{
Water Quality and Bed Sediment Quality in the Albemarle Sound, North Carolina, 2012-14
}

\author{
Michelle C. Moorman, Sharon A. Fitzgerald, Laura N. Gurley, Ahmed Rhoni-Aref, and Keith A. Loftin
}

\section{Abstract}

The Albemarle Sound region was selected in 2012 as one of two demonstration sites in the Nation to test and improve the design of the National Water Quality Monitoring Council's National Monitoring Network (NMN) for U.S. Coastal Waters and Tributaries. The goal of the NMN for U.S. Coastal Waters and Tributaries is to provide information about the health of our oceans, coastal ecosystems, and inland influences on coastal waters for improved resource management. The NMN is an integrated, multidisciplinary, and multi-organizational program using multiple sources of data and information to augment current monitoring programs.

This report presents and summarizes selected waterquality and bed sediment-quality data collected as part of the demonstration project conducted in two phases. The first phase was an occurrence and distribution study to assess nutrients, metals, pesticides, cyanotoxins, and phytoplankton communities in the Albemarle Sound during the summer of 2012 at 34 sites in Albemarle Sound, nearby sounds, and various tributaries. The second phase consisted of monthly sampling over a year (March 2013 through February 2014) to assess seasonality in a more limited set of constituents including nutrients, cyanotoxins, and phytoplankton communities at a subset (eight) of the sites sampled in the first phase. During the summer of 2012, few constituent concentrations exceeded published waterquality thresholds; however, elevated levels of chlorophyll $a$ and $\mathrm{pH}$ were observed in the northern embayments and in Currituck Sound. Chlorophyll $a$, and metals (copper, iron, and zinc) were detected above a water-quality threshold. The World Health Organization provisional guideline based on cyanobacterial density for high recreational risk was exceeded in approximately 50 percent of water samples collected during the summer of 2012. Cyanobacteria capable of producing toxins were present, but only low levels of cyanotoxins below human health benchmarks were detected. Finally, 12 metals in surficial bed sediments were detected at levels above a published sediment-quality threshold. These metals included chromium, mercury, copper, lead, arsenic, nickel, and cadmium. Sites with several metal concentrations above the respective thresholds had relatively high concentrations of organic carbon or fine sediment (silt plus clay), or both and were predominantly located in the western and northwestern parts of the Albemarle Sound.

Results from the second phase were generally similar to those of the first in that relatively few constituents exceeded a water-quality threshold, both $\mathrm{pH}$ and chlorophyll $a$ were detected above the respective water-quality thresholds, and many of these elevated concentrations occurred in the northern embayments and in Currituck Sound. In contrast to the results from phase one, the cyanotoxin, microcystin was detected at more than 10 times the water-quality threshold during a phytoplankton bloom on the Chowan River at Mount Gould, North Carolina in August of 2013. This was the only cyanotoxin concentration measured during the entire study that exceeded a respective water-quality threshold.

The information presented in this report can be used to improve understanding of water-quality conditions in the Albemarle Sound, particularly when evaluating causal and response variables that are indicators of eutrophication. In particular, this information can be used by State agencies to help develop water-quality criteria for nutrients, and to understand factors like cyanotoxins that may affect fisheries and recreation in the Albemarle Sound region.

\section{Introduction}

The Albemarle Sound region was selected in 2012 as one of two demonstration sites in the Nation to test and improve the design of the National Water Quality Monitoring Council's National Monitoring Network (NMN) for U.S. Coastal Waters and Tributaries. The goal of the NMN for U.S. Coastal Waters and Tributaries is to provide information about the health of our oceans, coastal ecosystems and inland influences on coastal waters for improved resource management. The NMN is an integrated, multidisciplinary, and multi-organizational program using multiple sources of data and information to augment current (2015) monitoring programs. 
The demonstration project began in February 2012, to document current and historic monitoring and research programs in the Albemarle Sound and identify monitoring gaps (Moorman and others, 2014). One of the identified data gaps was the need for increased monitoring of nutrients, metals, pesticides, and phytoplankton communities in the Albemarle Sound. As part of the demonstration project, the U.S. Geological Survey (USGS) collaborated with the North Carolina Department of Environment and Natural Resources (NCDENR) Division of Water Resources (DWR) to address this monitoring gap. This information can be used by DWR and its partners to help develop nutrient criteria for the Albemarle Sound region under the Clean Water Act of 1972.

\section{Background}

The Albemarle Sound is part of the Albemarle-Pamlico estuarine system, the second largest estuary in the lower 48 States of the United States (Giordano and Holloman, 2001). Albemarle Sound and its tributaries form a shallow, low salinity lagoonal estuary (Jia and Li, 2012) oriented east to west in northeastern North Carolina and southeastern Virginia (fig. 1). The Albemarle Sound covers a surface area of 2,330 square kilometers surrounded by more than 800 kilometers $(\mathrm{km})$ of shoreline and has a drainage area of 47,552 square kilometers (Steel, 1991). For the purpose of this report, the Albemarle Sound study area has been defined as a region including the Pasquotank, Lower Roanoke, and Chowan River Basins that includes the waters and adjacent wetlands draining into and out of the Albemarle Sound. In addition, lower portions of the Meherrin, Nottoway, and Blackwater River Basins are included because most of the Chowan River is tidally influenced. The precise boundary of the study area was based on the boundaries of the hydrologic units identified by their USGS 12-digit hydrologic unit codes.

The Albemarle Sound study area lies completely within the Coastal Plain of North Carolina and Virginia and comprises an extensive complex of creeks, rivers, wetlands, and open sound. In their calculations of the annual water budget for the Albemarle Sound, Giese and others (1979) computed an average influx of 17,000 cubic feet per second $\left(\mathrm{ft}^{3} / \mathrm{s}\right)$ of water entering the Albemarle Sound. Although runoff and precipitation vary seasonally, annual mean flow estimates based on data from USGS streamgages indicated the Roanoke and Chowan Rivers contribute 8,900 and 4,600 ft3 $/ \mathrm{s}$, respectively. Several smaller rivers and tidal creeks drain coastal-area swamps, including the Perquimans, Little, Pasquotank, and North Rivers in the northern part of the Albemarle Sound and the Scuppernong and Alligator Rivers in the southern part of the sound, but they accounted for only a quarter (approximately 2,900 $\mathrm{ft}^{3} / \mathrm{s}$ ) of the total freshwater inflow to the sound. An additional $3,400 \mathrm{ft}^{3} / \mathrm{s}$ of water was estimated to be contributed by direct precipitation on the water surface. Although the Giese and others (1979) study is nearly 30 years old, it is still the most current and used streamflow data that dated back to the 1920 s for some sites. The approximate residence time of water in the sound is 45 days because there is no direct connection to, and little exchange with, the Atlantic Ocean. Barrier islands form the eastern boundary of the study area and isolate the sound from the ocean (Giese and others, 1979). Because there is little tidal exchange between the Albemarle Sound and Oregon Inlet, wind-driven tides are the primary driver of water movement in the sound, with southwesterly winds predominating except during major storm events (Jia and Li, 2012).

The climate for the region is relatively mild, with mean winter temperatures ranging between 6 and 8 degrees Celsius and mean summer temperatures commonly exceeding 32 degrees Celsius. Mean annual precipitation in the study area ranges from 111 to 137 centimeters per year (Parameterelevation Regressions on Independent Slopes Model [PRISM], 2012). There is little seasonal variation in rainfall, but the amount can vary substantially between dry years, when total precipitation can be less than 89 centimeters, and wet years, when total precipitation can exceed 200 centimeters (Carpenter and Dubbs, 2012). The Albemarle Sound region has been recognized as a location most likely to be affected by climate change because of its geography (Ezer and others, 2013).

The Albemarle Sound study area is predominantly rural, with a population of approximately 520,000 people and few urban areas, except for tourism-related development near the coast along the barrier islands and City of Virginia Beach suburbs (U.S. Census Bureau, 2011). According to the 2006 National Land Cover Database, 28.1 percent of the land in the study area was wetland; 24.1 percent was cropland; 15.1 percent was forested; 21.2 percent was open water; 6.4 percent was barren, shrub/scrub, or grassland; and 5.2 percent was classified as developed (Fry and others, 2011). Before settlement, much of the land consisted of peat wetlands known as pocosins. In the past century, most of the pocosins have been ditched and drained to allow agricultural and silvicultural activities (Copeland and others, 1983). In general, there has been a decline in the extent of forests and wetlands in the area during the past 20 years (Carpenter and Dubbs, 2012, p. 45-53). Accelerated eutrophication from increased nutrient inputs associated with changing land use is of concern.

Harmful algal blooms can disrupt aquatic ecosystems and trigger fish kills from bloom decomposition and food web changes (Burkholder, 1998; Anderson and others, 2002). Cyanobacteria and cylindrospermopsin, a cyanotoxin produced by certain species of cyanobacteria, were previously found in the Currituck Sound in a 2006-07 study (Calandrino and Paerl, 2011; Paerl and Otten, 2013). Previous research has demonstrated that the eastern Albemarle Sound is receiving nutrient and microbial pathogen inputs from the highly developed town of Nags Head (not shown) at the southeastern end of Albemarle Sound on the Outer Banks (Mallin and others, 2006). More information on nutrient enrichment/cyanobacteria density relations in the Albemarle Sound is needed to support nutrient criteria development. 


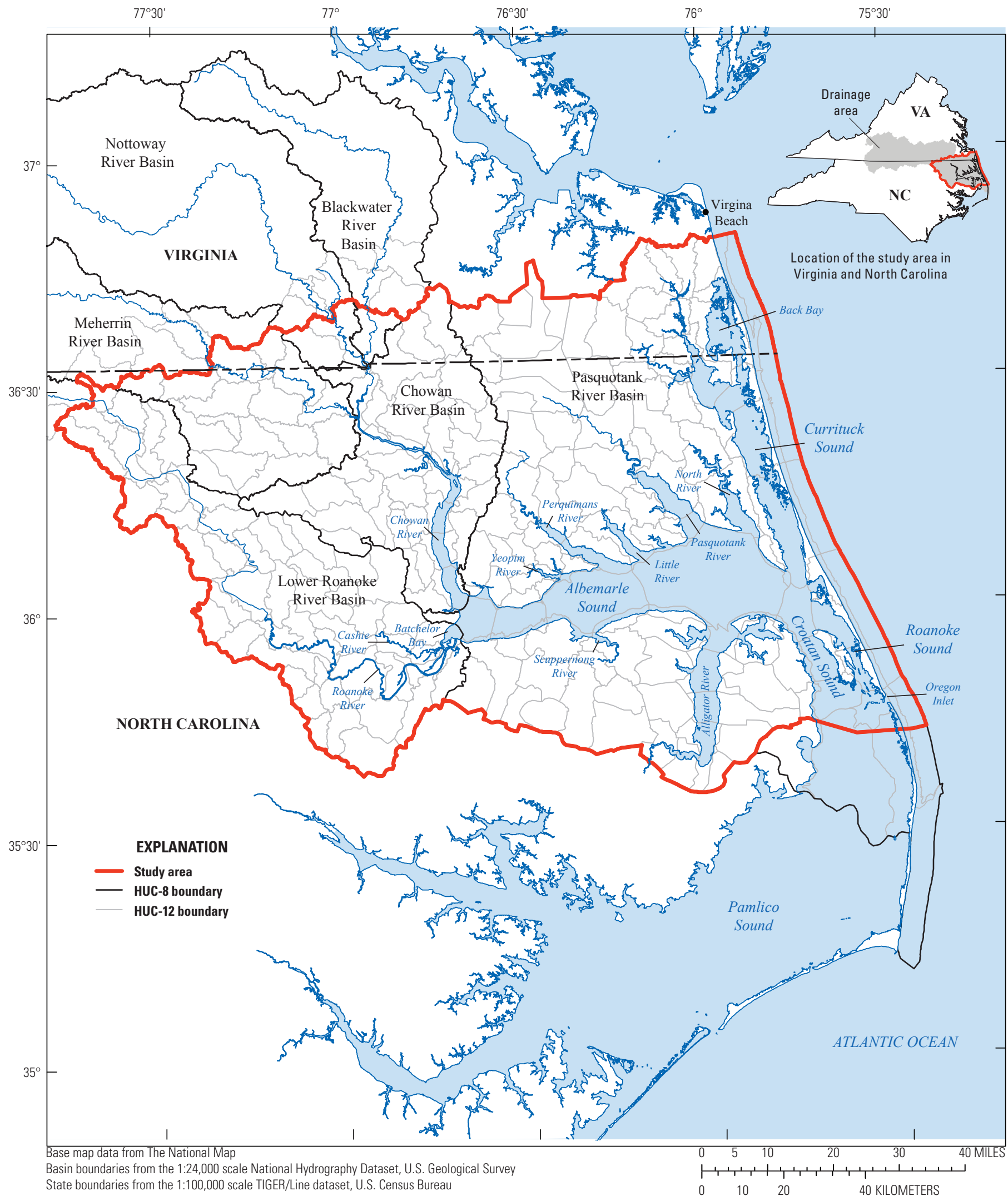

Figure 1. Basins and subbasins in the Albemarle Sound study area. 
The co-occurrence of freshwater and marine harmful algal bloom species and their toxins in coastal environments is an important field of research, with implications for managing our coastal resources (Miller and others, 2010; Lehman and others, 2005; Gibble and Kudela, 2014; Drake and others, 2010). The U.S. Environmental Protection Agency (EPA) is requiring North Carolina to develop numeric nutrient criteria for all water body types including estuaries, with the Albemarle Sound being the pilot estuary (North Carolina Department of Environment and Natural Resources Division of Water Resources, 2014).

\section{Purpose and Scope}

The purpose of this report is to present and summarize water-quality and bed sediment-quality data collected as part of the demonstration project. This information will improve understanding of current (2015) water-quality conditions in the Albemarle Sound with a specific emphasis on evaluating causal and response variables that are indicators of eutrophication. In addition, the occurrence and distribution of three cyanotoxins, as well as two modern-use pesticides, were determined. This report includes all water-quality and bed sediment-quality data collected between 2012 and 2014 as part of the Albemarle Sound NMN demonstration project and summarizes all methods and techniques used for data collection and analysis. Specifically, the following data are presented:

- In July and August of 2012, a sound-wide synoptic was conducted at 34 sites to characterize summer water-quality conditions and spatial variability in the Albemarle Sound. Samples were analyzed for more than 40 water-quality constituents including nutrients, major ions, trace metals, chlorophyll $a$, pesticides, and cyanotoxins. Vertical profiles of dissolved oxygen, $\mathrm{pH}$, temperature, and specific conductance/salinity were recorded. Phytoplankton community composition, density, and biovolume were assessed for each sample, and estimates of light attenuation were made using a Secchi disk.

- In October of 2012, bed sediment samples were collected at 20 sites and assessed for metals, nutrients, total organic carbon, and particle size.

- During March 2013 through February 2014, water samples were collected monthly at 8 sites and analyzed for more than 20 constituents including nutrients, dissolved organic carbon, dissolved silica, and chlorophyll $a$, to complement water-quality data collection efforts for the State and to improve understanding of water-quality conditions in previously unmonitored embayments of the Albemarle Sound. Vertical profiles of dissolved oxygen, $\mathrm{pH}$, temperature, and specific conductance/salinity were recorded. Estimates of water transparency were made using a Secchi disk. In addition, pesticides; cyanotoxins; and phytoplankton community composition, density, and biovolume were assessed between one and three times (April, July, and October 2013) at seven of the eight USGS sites; and phytoplankton metrics were assessed once in September 2013 at the eighth site (362019075531301). Pesticides and phytoplankton metrics were assessed in April and July 2013 at four additional monitoring stations operated by NCDENR DWR in the Albemarle Sound. Cyanotoxins were assessed at three of these four DWR sites (excluding 0208117828) during the same 2 months. Finally, pesticides and cyanotoxins also were assessed during phytoplankton blooms at three sites in the Chowan River- one originally sampled during the summer of 2012 and two new sites not previously sampled. Results from USGS monitoring activities are presented.

- Replicate samples of suspended sediment, nutrients, and chlorophyll $a$ were collected and submitted to State, USGS, and contract labs to assess the comparability of data collected by multiple agencies. Results from these comparability assessments are presented.

- Data for specific constituents are compared to current (2015) state and federal guidelines and standards for water and bed sediment quality (when available).

\section{Methods}

The sampling design and methods for sampling, analysis, and data handling are presented in the following section. Physical, chemical, and biological components of water quality and bed sediment quality were studied in two phasesduring the summer of 2012 and during March 2013 through February 2014.

\section{Sampling Design}

During the summer of 2012, vertically integrated photiczone samples and vertical profiles were collected at 34 sites at least once in each of the major tributaries and several openwater sites in Albemarle Sound (table 1 and fig. 2). Sites were located in the Chowan, Roanoke, Pasquotank, Perquimans, Scuppernong, Little, Yeopim, Alligator, North, and Cashie Rivers; Albemarle, Croatan and Currituck Sounds; and Back and Batchelor (also Bachelor) Bays. When possible, sites were co-located with past and current sites of several agencies including the USGS, North Carolina Division of Marine Fisheries, East Carolina University, NCDENR DWR, and the U.S. Fish and Wildlife Service. Photic-zone samples (defined as twice the Secchi depth; North Carolina Department of Environment and Natural Resources, 2013) were analyzed for 


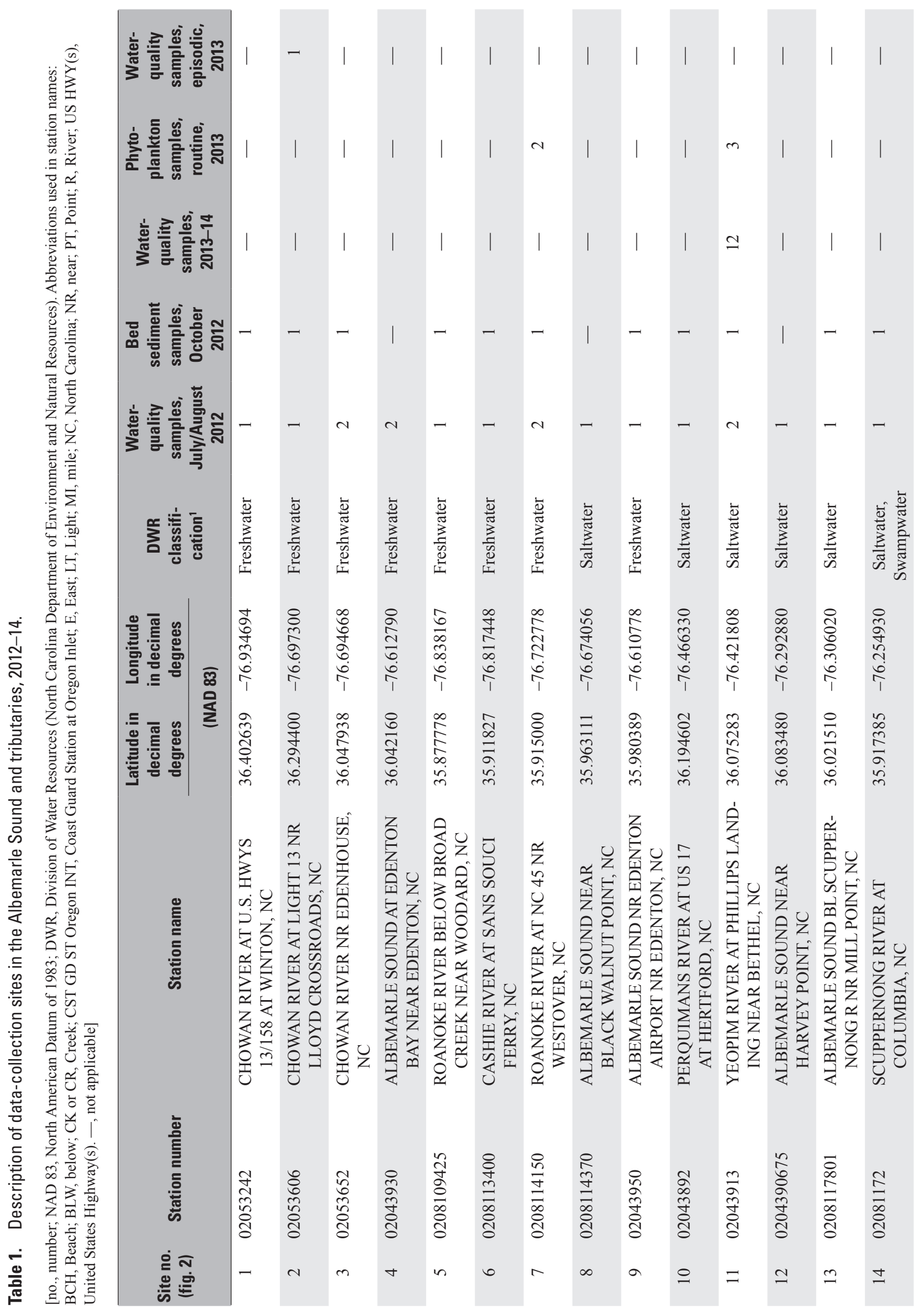




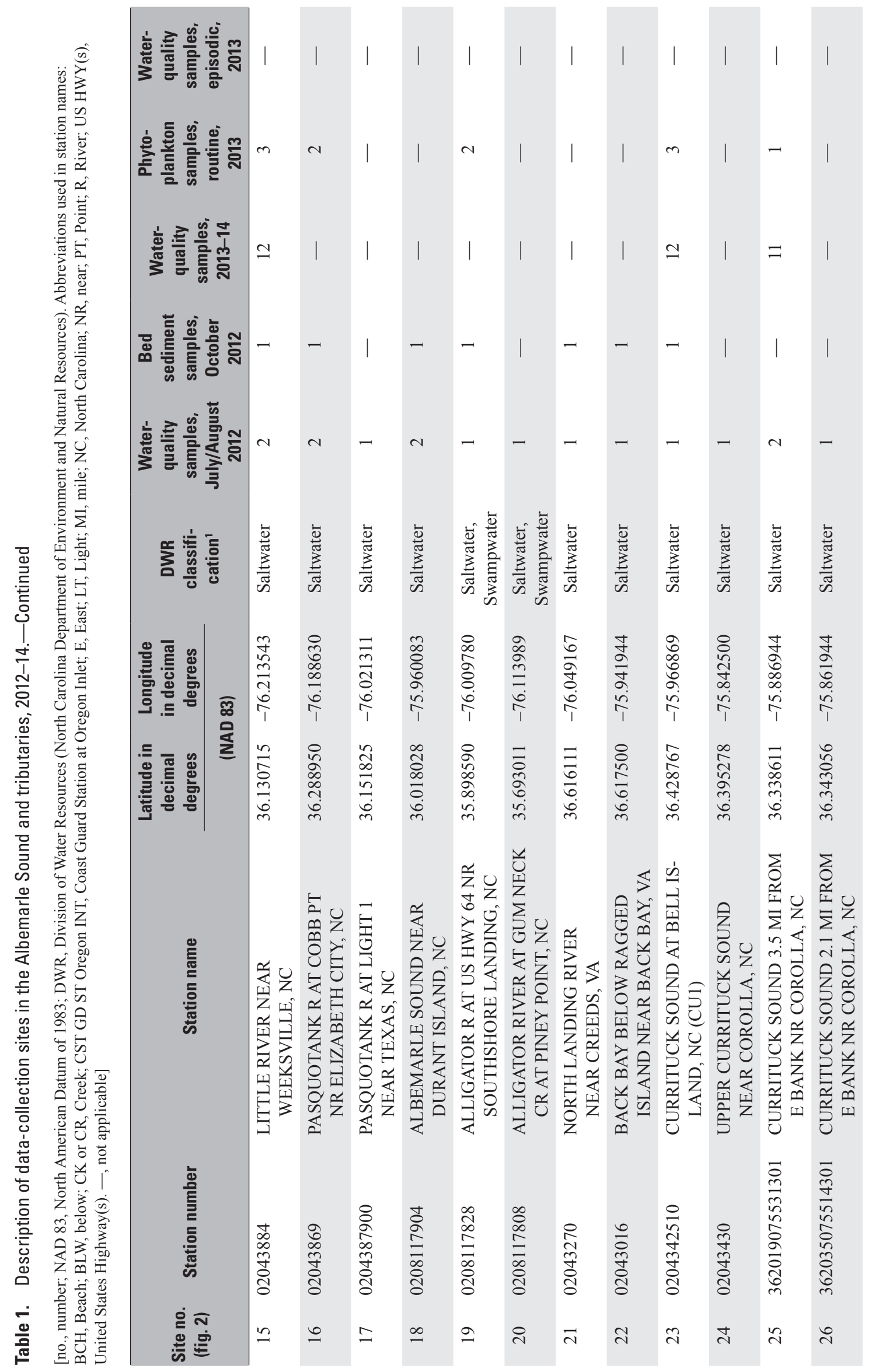




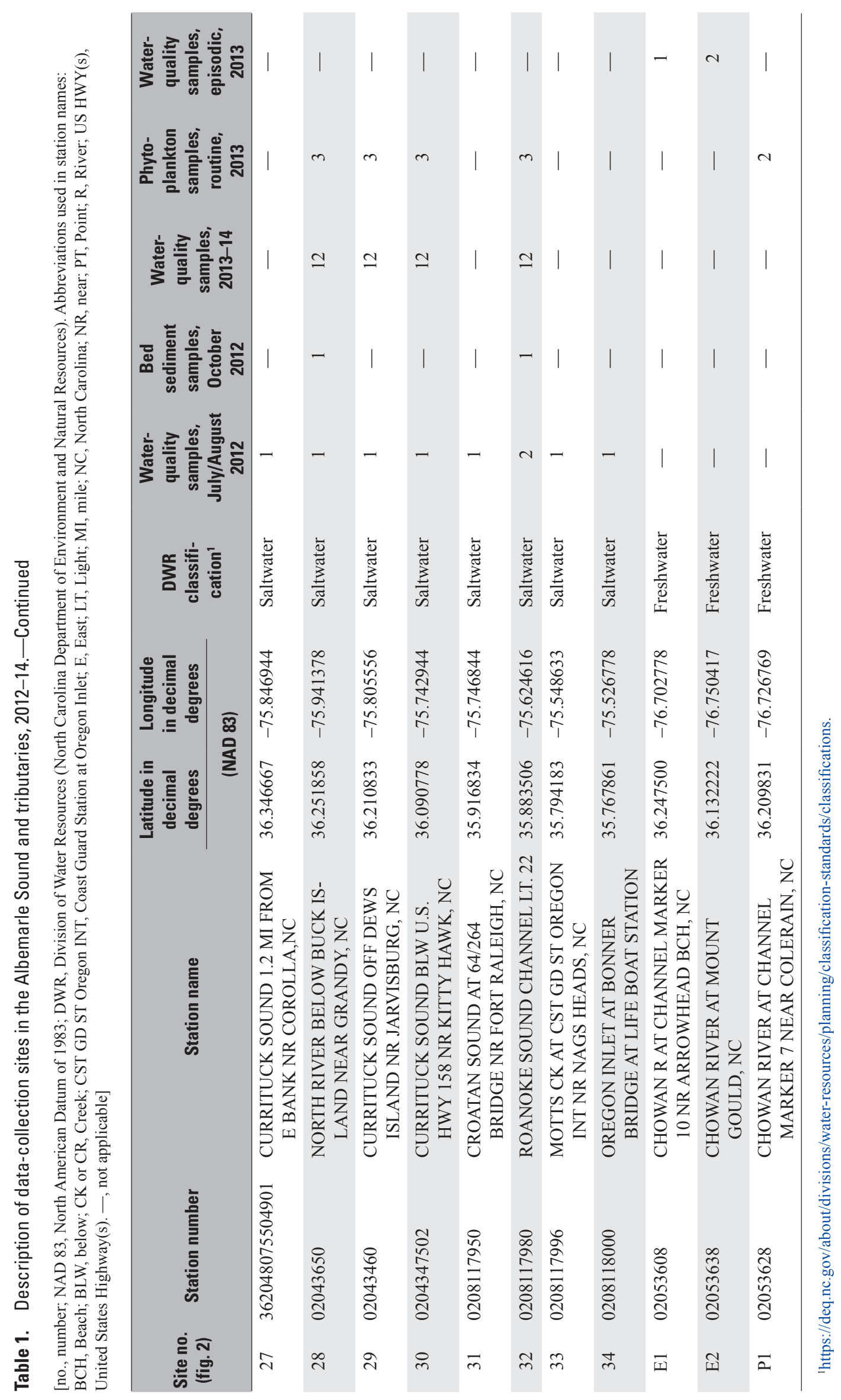




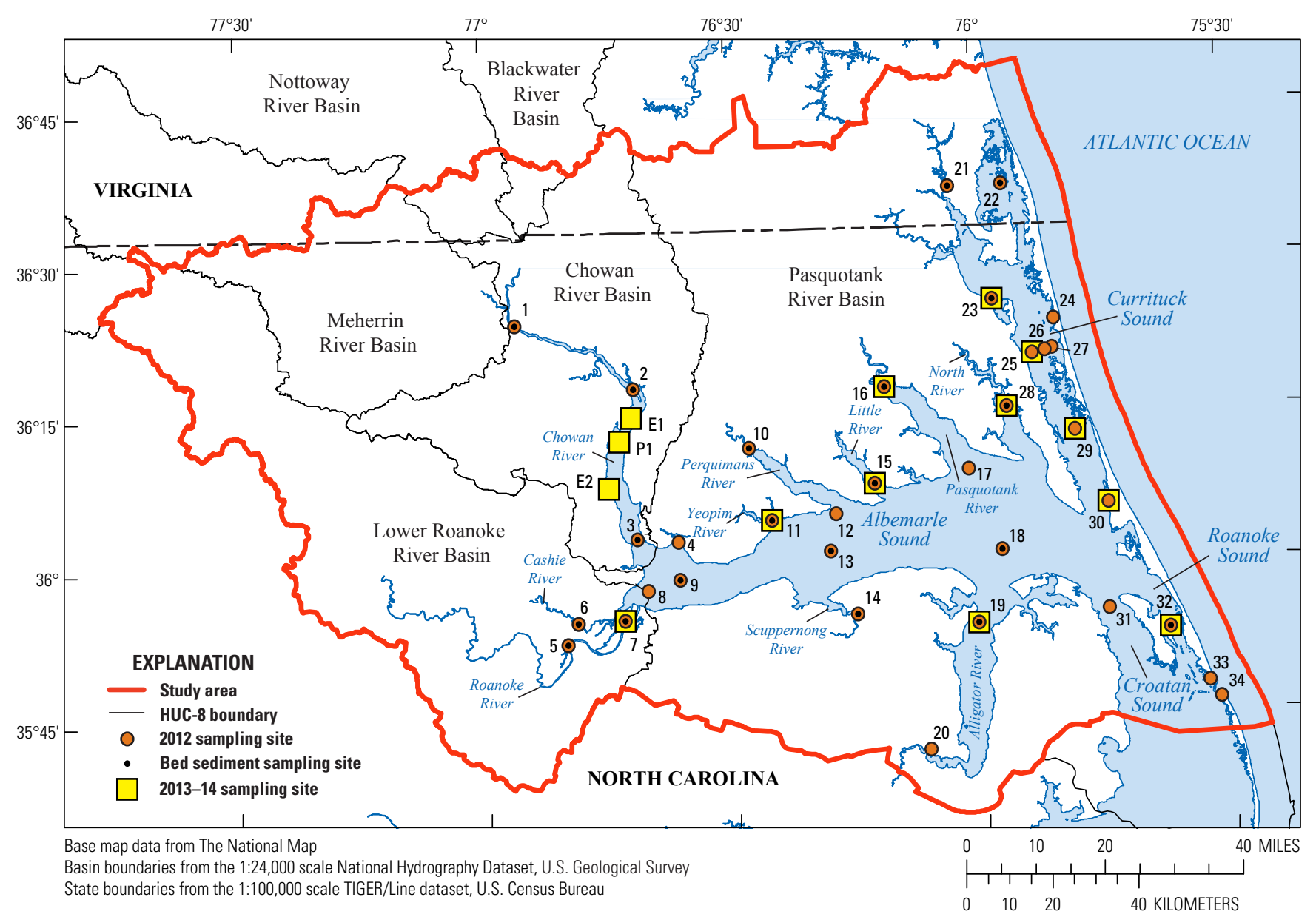

Figure 2. Sites sampled in the Albemarle Sound and tributaries, 2012-14.

nutrients, cyanotoxins, pesticides (atrazine and glyphosate), metals, total suspended solids, chlorophyll $a$, phytoplankton community characteristics (composition, density, and biovolume), and other ancillary data.

During October of 2012, bed sediment samples were collected at a subset of 20 of the sites sampled for water quality. Sites were selected to include fish nursery habitats and to represent all parts of the Albemarle Sound and surrounding rivers (table 1 and fig. 2). The overall objective of the bed sediment sampling was to document the occurrence and distribution of the total recoverable concentration (considered to approximate the bioavailable fraction) of several metals that are potentially toxic to benthic organisms. Particle size distribution also was determined on all samples.

During March 2013 through February 2014, a subset of eight sites from the 2012 sites (table 1) was sampled on a monthly basis to supplement the NCDENR DWR monthly monitoring program of nutrient and phytoplankton data. This supplemental sampling filled a gap identified during the NMN analysis (Moorman and others, 2014). Priority was given to sites located in important nursery habitats where high values of chlorophyll $a$, cyanobacterial colonies, or cyanotoxins were observed during 2012. Cyanotoxins are not currently (2015) being sampled by the State's monitoring network.
Water samples from these eight sites were analyzed for total suspended and dissolved solids, chlorophyll $a$, nutrients, dissolved organic carbon, light attenuation, and other ancillary data. During the April, July, and October sampling dates, additional constituents including phytoplankton community composition, density, and biovolume; pesticides; and cyanotoxins were sampled at these eight sites plus at four additional sites in 2013 (table 1 and fig. 2) to document these biological and chemical conditions during the growing season. Finally, three sites were sampled in 2013 in response to reported phytoplankton blooms ("episodic samples").

\section{Sample Collection, Analysis, and Data Handling}

All water and bed sediment samples were collected and processed in accordance with the National Field Manual of the USGS (U.S. Geological Survey, variously dated). Vertical profiles of dissolved oxygen, $\mathrm{pH}$, temperature, and specific conductance were measured with a multiparameter sonde. Vertically integrated samples for chemical constituents were collected with a 2-liter, weighted-bottle sampler from the top of the water column to a depth equal to two times the Secchi depth. The vented sampler was raised and lowered as it filled through a small orifice. 
Constituents, analyzing laboratories, and references for all laboratory methods are shown in table 2. USGS laboratories were used for all chemical analysis of water samples except chlorophyll $a$, which was analyzed by Meritech Environmental Laboratories, Inc., a laboratory certified by NCDENR DWR for this analysis. Published methods were used except for glyphosate, which was analyzed by magnetic particle enzyme-linked immunosorbent assay (ELISA) kits obtained from Abraxis LLC (Warminster, Pennsylvania). The samples were analyzed using the manufacturer's procedures except for the derivitization step; samples were derivitized in 10-milliliter $(\mathrm{mL})$ plastic vials instead of glass test-tubes. Recovery losses from glyphosate binding to free siliconoxygen groups were avoided and plastic has been in use with this method for more than 10 years.

Relative stratification of the water column was assessed by calculating the vertical density gradient. Vertical profiles of salinity (or specific conductance) and temperature were recorded in either 1 foot ( 0.3 meter) or 0.5 meter intervals. Salinity was calculated from specific conductance by either the sonde software or within a spreadsheet using a bestfit quadratic curve $\left(r^{2}=0.9999\right)$ when the sonde was not programmed to calculate salinity. Water density $(\rho)$ in kilograms per cubic meter $\left(\mathrm{kg} / \mathrm{m}^{3}\right)$ was calculated as a function of salinity and temperature for brackish and salt waters or as a function of temperature alone in freshwater using the equations of McCutcheon and others (1993). Relative density differentials (RDD), in percent, were calculated as the absolute difference between the density at the top and bottom of the water column divided by the average of the top and bottom times 100 .

Phytoplankton samples were collected, preserved, and analyzed in accordance with the standard operating procedures of DWR (North Carolina Department of Environment and Natural Resources Division of Water Quality, 2003). The DWR Water Sciences Section performed all phytoplankton analyses, including taxonomic identification to the genus or species level and density determinations that included cell counts (density) and total biovolume estimates. Cell density and biovolume were computed, reported without rounding, and likely reflect too much precision. Standard rounding procedures are in development by the DWR.

Surficial bed sediment was sampled with an Ekman dredge. Overlying water was decanted before collection of the upper approximately 5 centimeters using a clean fluoropolymer tube. Wet sediment was thoroughly mixed in a clean glass bowl before filling clean, combusted glass jars. Samples were kept chilled from collection and during shipment to the contract laboratory (TestAmerica Laboratories, Inc., Burlington, Vermont). Total recoverable metals were extracted using nitric acid and hydrogen peroxide (U.S. Environmental Protection Agency, 1992). This extraction method is efficient and includes most trace metals not associated with the mineral matrix. Because metals within mineral matrices are not thought to be as bioavailable as metals adsorbed to the mineral surfaces, total recoverable metals is presumably a closer approximation to the fraction of total metals that aquatic organisms might incorporate in tissues.

Chemical and physical data for water and bed sediment samples were reviewed according to USGS standard protocol (U.S. Geological Survey, 2010) and are publicly available from the USGS National Water Information System (NWIS) (http://dx.doi.org/10.5066/F7P55KJN). Water-quality data, in addition to all the quality control data, are also available in Fitzgerald and Gurley (2016; https://dx.doi.org/10.5066/ F7057D2V).

\section{Quality Assurance and Control}

Quality assurance entailed adherence to USGS standard operating procedures for field measurements and sample collection, handling, and analysis by trained personnel (U.S. Geological Survey, variously dated). These procedures included training personnel, calibration of field equipment, use of clean sampling techniques, adherence to maximum hold times, maintenance of correct storage conditions, and review of analytical performance data. Quality control samples were collected to assess bias and variability in constituent concentrations in water (appendix table 1-1a; all appendix tables are available for download at https:/doi.org/10.3133/ ofr20161171); variability of phytoplankton composition, density, and biovolume and cyanobacteria density in water (appendix table 1-2a); and bias and variability in constituent concentrations in bed sediment (appendix table 1-3a). For all of the ELISA analyses (pesticides and cyanotoxins), the manufacturer's standards and blank solutions and controls were used. The standard curves were constructed using a 4-parameter fit. In addition, after every 10 environmental samples, a duplicate and a spiked environmental sample were analyzed.

Bias of 32 constituent concentrations in water samples was assessed with 5 field blanks yielding 114 total analyses (appendix table 1-1b). The total was less than 160 analyses (32 constituents times 5 blanks) because not all constituents were analyzed in every blank. The six detections (5 percent of all analyses) included one instance each of sodium, chloride, sulfate, and manganese and two instances of cobalt. Detections were evaluated in relation to constituent reporting levels and to concentrations observed in environmental samples.

In most cases, the detections in the field blanks were within about a factor of two compared to the reporting level and thus were quite low. In one case, a cobalt detection of 0.172 micrograms per liter $(\mu \mathrm{g} / \mathrm{L})$ was more than eight times higher than the reporting level of $0.021 \mu \mathrm{g} / \mathrm{L}$.

The detections in these field blanks also were compared to the median and range of concentrations in the environmental data to determine if a positive bias affected the data. First, the highest concentration found in a field blank was multiplied by a factor of five to approximate a raised reporting level against which the environmental samples should be assessed. Then the percentage of environmental concentrations below that calculated concentration was determined for each of the five constituents. For all constituents except cobalt, 
Table 2. Analytical information for physical properties and chemical constituents measured in samples of water and bed sediments collected in the Albemarle Sound and tributaries, 2012-14.

[NWIS, National Water Information System. Analyzing laboratory: NWQL, National Water Quality Laboratory; OGRL, Organic Geochemistry Research Laboratory (USGS); TA, TestAmerica Laboratories, Inc. CAS RN, Chemical Abstract Services Registry Number. Abbreviations used in units: $\mathrm{CaCO}_{3}$, calcium carbonate; ${ }^{\circ} \mathrm{C}$, degree Celsius; m, meter; mg/kg, milligram per kilogram; mg/L, milligram per liter; mm Hg, millimeter of mercury; N, nitrogen; P, phosphorus; PSS, Practical Salinity Scale; std, standard; $\mathrm{SiO}_{2}$, silicon dioxide; $\mu \mathrm{g} / \mathrm{l}$, microgram per liter; $\mu \mathrm{S} / \mathrm{cm}$, microSiemen per centimeter; $\mathrm{Wt} \%$, weight percent. —, not applicable]

\begin{tabular}{|c|c|c|c|c|c|c|}
\hline \multirow{2}{*}{$\begin{array}{l}\text { Property or } \\
\text { constituent }\end{array}$} & \multirow{2}{*}{$\begin{array}{l}\text { NWIS } \\
\text { parameter } \\
\text { code }\end{array}$} & \multirow{2}{*}{$\begin{array}{l}\text { Analyzing } \\
\text { laboratory }\end{array}$} & \multirow{2}{*}{${ }^{1}$ CAS RN } & \multicolumn{2}{|c|}{ Reporting level } & \multirow{2}{*}{ Reference } \\
\hline & & & & Value & Unit & \\
\hline \multicolumn{7}{|c|}{ Air } \\
\hline Barometric pressure & 00025 & (field) & - & - & $\mathrm{mm} \mathrm{Hg}$ & $\begin{array}{l}\text { U.S. Geological Survey } \\
\text { (variously dated) }\end{array}$ \\
\hline \multicolumn{7}{|c|}{ Water } \\
\hline $\begin{array}{l}\text { Acid neutralizing capacity, } \\
\text { water, unfiltered, }\end{array}$ & 90410 & NWQL & - & 4 & $\mathrm{mg} / \mathrm{L} \mathrm{CaCO}_{3}$ & Fishman and Friedman (1989) \\
\hline $\begin{array}{l}\text { Alkalinity, water, filtered, } \\
\text { field }\end{array}$ & 39086 & NWQL & - & - & $\mathrm{mg} / \mathrm{L} \mathrm{CaCO}_{3}$ & $\begin{array}{l}\text { U.S. Geological Survey } \\
\text { (variously dated) }\end{array}$ \\
\hline $\begin{array}{l}\text { Alkalinity, water, filtered, } \\
\text { laboratory }\end{array}$ & 29801 & NWQL & - & 4.6 & $\mathrm{mg} / \mathrm{L} \mathrm{CaCO}_{3}$ & Fishman and Friedman (1989) \\
\hline Aluminum, water, filtered & 01106 & NWQL & $7429-90-5$ & 2.2 & $\mu \mathrm{g} / \mathrm{L}$ & Faires (1993) \\
\hline $\begin{array}{l}\text { Ammonia plus organic nitro- } \\
\text { gen, water, unfiltered }\end{array}$ & 00625 & NWQL & - & 0.07 & $\mathrm{mg} / \mathrm{L}$ as $\mathrm{N}$ & Patton and Truitt (2000) \\
\hline Ammonia, water, filtered & 00608 & NWQL & $7664-41-7$ & 0.01 & $\mathrm{mg} / \mathrm{L}$ as $\mathrm{N}$ & Fishman (1993) \\
\hline $\begin{array}{l}\text { Atrazine, water, filtered, } \\
\text { immunoassay, unadjusted, } \\
\text { recoverable }\end{array}$ & 99775 & OGRL & $1912-24-9$ & 0.1 & $\mu \mathrm{g} / \mathrm{L}$ & Aga and Thurman (1995) \\
\hline $\begin{array}{l}\text { Bicarbonate, water, filtered, } \\
\text { field }\end{array}$ & 00453 & NWQL & $71-52-3$ & - & $\mathrm{mg} / \mathrm{L}$ & Rounds (2012) \\
\hline Calcium, water, filtered & 00915 & NWQL & $7440-70-2$ & 0.022 & $\mathrm{mg} / \mathrm{L}$ & Fishman (1993) \\
\hline $\begin{array}{l}\text { Carbonate, water, filtered, } \\
\text { field }\end{array}$ & 00452 & NWQL & $3812-32-6$ & - & $\mathrm{mg} / \mathrm{L}$ & Rounds (2012) \\
\hline Chloride, water, filtered & 00940 & NWQL & $16887-00-6$ & 0.06 & $\mathrm{mg} / \mathrm{L}$ & Fishman (1993) \\
\hline Chlorophyll $a$, phytoplankton & 70953 & Meritech & $479-61-8$ & 1.0 & $\mu \mathrm{g} / \mathrm{L}$ & $\begin{array}{l}\text { U.S. Environmental Protection } \\
\text { Agency (1997a) }\end{array}$ \\
\hline Cobalt, water, filtered & 01035 & NWQL & $7440-48-4$ & 0.021 & $\mu \mathrm{g} / \mathrm{L}$ & Garbarino and others (2006) \\
\hline Copper, water, filtered & 01040 & NWQL & $7440-50-8$ & 0.8 & $\mu \mathrm{g} / \mathrm{L}$ & Garbarino and others (2006) \\
\hline $\begin{array}{l}\text { Dissolved oxygen, water, } \\
\text { unfiltered }\end{array}$ & 00300 & (field) & $7782-44-7$ & - & $\mathrm{mg} / \mathrm{L}$ & $\begin{array}{l}\text { American Society for Testing } \\
\text { and Materials (2010) }\end{array}$ \\
\hline Fluoride, water, filtered & 00950 & NWQL & $16984-48-8$ & 0.04 & $\mathrm{mg} / \mathrm{L}$ & Fishman and Friedman (1989) \\
\hline $\begin{array}{l}\text { Glyphosate, water, filtered, } \\
\text { recoverable }\end{array}$ & 99960 & OGRL & $1071-83-6$ & 0.1 & $\mu \mathrm{g} / \mathrm{L}$ & $\begin{array}{l}\text { Meyers (unpublished method, } \\
\text { see text) }\end{array}$ \\
\hline Iron, water, filtered & 01046 & NWQL & $7439-89-6$ & 3.2 & $\mu \mathrm{g} / \mathrm{L}$ & Fishman (1993) \\
\hline Lead, water, filtered & 01049 & NWQL & $7439-92-1$ & 0.025 & $\mu \mathrm{g} / \mathrm{L}$ & Faires (1993) \\
\hline Magnesium, water, filtered & 00925 & NWQL & $7439-95-4$ & 0.011 & $\mathrm{mg} / \mathrm{L}$ & Fishman (1993) \\
\hline Manganese, water, filtered & 01056 & NWQL & $7439-96-5$ & 0.16 & $\mu \mathrm{g} / \mathrm{L}$ & Fishman (1993) \\
\hline Manganese, water, filtered & 01056 & NWQL & $7439-96-5$ & 0.4 & $\mu \mathrm{g} / \mathrm{L}$ & Faires (1993) \\
\hline
\end{tabular}


Table 2. Analytical information for physical properties and chemical constituents measured in samples of water and bed sediments collected in the Albemarle Sound and tributaries, 2012-14.-Continued

[NWIS, National Water Information System. Analyzing laboratory: NWQL, National Water Quality Laboratory; OGRL, Organic Geochemistry Research Laboratory (USGS); TA, TestAmerica Laboratories, Inc. CAS RN, Chemical Abstract Services Registry Number. Abbreviations used in units: $\mathrm{CaCO}_{3}$, calcium carbonate; ${ }^{\circ} \mathrm{C}$, degree Celsius; m, meter; mg/kg, milligram per kilogram; mg/L, milligram per liter; mm Hg, millimeter of mercury; N, nitrogen; P, phosphorus; PSS, Practical Salinity Scale; std, standard; $\mathrm{SiO}_{2}$, silicon dioxide; $\mu \mathrm{g} / 1$, microgram per liter; $\mu \mathrm{S} / \mathrm{cm}$, microSiemen per centimeter; $\mathrm{Wt} \%$, weight percent. —, not applicable]

\begin{tabular}{|c|c|c|c|c|c|c|}
\hline \multirow{2}{*}{$\begin{array}{l}\text { Property or } \\
\text { constituent }\end{array}$} & \multirow{2}{*}{$\begin{array}{c}\text { NWIS } \\
\text { parameter } \\
\text { code }\end{array}$} & \multirow{2}{*}{$\begin{array}{l}\text { Analyzing } \\
\text { laboratory }\end{array}$} & \multirow{2}{*}{${ }^{1}$ CAS RN } & \multicolumn{2}{|c|}{ Reporting level } & \multirow{2}{*}{ Reference } \\
\hline & & & & Value & Unit & \\
\hline \multicolumn{7}{|c|}{ Water-Continued } \\
\hline Molybdenum, water, filtered & 01060 & NWQL & $7439-98-7$ & 0.014 & $\mu \mathrm{g} / \mathrm{L}$ & Faires (1993) \\
\hline Nickel, water, filtered & 01065 & NWQL & $7440-02-0$ & 0.09 & $\mu \mathrm{g} / \mathrm{L}$ & Garbarino and others (2006) \\
\hline $\begin{array}{l}\text { Nitrate plus nitrite, water, } \\
\text { filtered }\end{array}$ & 00631 & NWQL & $\begin{array}{l}14797-55-8+ \\
14797-65-0\end{array}$ & 0.04 & $\mathrm{mg} / \mathrm{L}$ as $\mathrm{N}$ & Patton and Kryskalla (2011) \\
\hline Nitrite, water, filtered & 00613 & NWQL & $14797-65-0$ & 0.001 & $\mathrm{mg} / \mathrm{L}$ as $\mathrm{N}$ & Fishman (1993) \\
\hline $\begin{array}{l}\text { Organic carbon, water, } \\
\text { filtered }\end{array}$ & 00681 & NWQL & - & 0.23 & $\mathrm{mg} / \mathrm{L}$ & Brenton and Arnett (1993) \\
\hline $\begin{array}{l}\text { Orthophosphate, water, } \\
\text { filtered }\end{array}$ & 00671 & NWQL & $14265-44-2$ & 0.004 & $\mathrm{mg} / \mathrm{L}$ as $\mathrm{P}$ & Fishman (1993) \\
\hline $\mathrm{pH}$, water, unfiltered, field & 00400 & (field) & - & - & std units & $\begin{array}{l}\text { U.S. Geological Survey } \\
\text { (variously dated) }\end{array}$ \\
\hline $\begin{array}{l}\text { Phosphorus, water, } \\
\text { unfiltered }\end{array}$ & 00665 & NWQL & $7723-14-0$ & 0.004 & $\mathrm{mg} / \mathrm{L}$ & $\begin{array}{l}\text { U.S. Environmental Protection } \\
\text { Agency (1993) }\end{array}$ \\
\hline Potassium, water, filtered & 00935 & NWQL & $7440-09-7$ & 0.03 & $\mathrm{mg} / \mathrm{L}$ & $\begin{array}{l}\text { American Public Health } \\
\text { Association (1998) }\end{array}$ \\
\hline $\begin{array}{l}\text { Salinity, water, unfiltered } \\
\quad \text { (calculated) }\end{array}$ & 90860 & (field) & - & - & PSS & Schemel (2001) \\
\hline Silica, water, filtered as $\mathrm{SiO}_{2}$ & 00955 & NWQL & $7631-86-9$ & 0.018 & $\mathrm{mg} / \mathrm{L}$ & Fishman (1993) \\
\hline Sodium, water, filtered & 00930 & NWQL & $7440-23-5$ & 0.06 & $\mathrm{mg} / \mathrm{L}$ & Fishman (1993) \\
\hline $\begin{array}{l}\text { Specific conductance, water, } \\
\text { unfiltered }\end{array}$ & 00095 & (field) & - & - & $\mu \mathrm{S} / \mathrm{cm}$ at $25^{\circ} \mathrm{C}$ & $\begin{array}{l}\text { U.S. Geological Survey } \\
\text { (variously dated) }\end{array}$ \\
\hline Sulfate, water, filtered & 00945 & NWQL & $14808-79-8$ & 0.09 & $\mathrm{mg} / \mathrm{L}$ & Fishman (1993) \\
\hline $\begin{array}{l}\text { Suspended solids, water, } \\
\text { unfiltered }\end{array}$ & 00530 & NWQL & - & 15 & $\mathrm{mg} / \mathrm{L}$ & Fishman and Friedman (1989) \\
\hline Temperature, water & 00010 & (field) & - & - & ${ }^{\circ} \mathrm{C}$ & $\begin{array}{l}\text { U.S. Geological Survey } \\
\text { (variously dated) }\end{array}$ \\
\hline $\begin{array}{l}\text { Total cylindrospermopsins, } \\
\text { recoverable }\end{array}$ & 89005 & OGRL & - & 0.05 & $\mu \mathrm{g} / \mathrm{L}$ & Graham and others (2010) \\
\hline $\begin{array}{l}\text { Total microcystins plus } \\
\text { nodularins, recoverable }\end{array}$ & 89011 & OGRL & - & 0.1 & $\mu \mathrm{g} / \mathrm{L}$ & Graham and others (2010) \\
\hline $\begin{array}{l}\text { Total nitrogen, water, } \\
\text { unfiltered }\end{array}$ & 00600 & NWQL & $7727-37-9$ & - & $\mathrm{mg} / \mathrm{L}$ & $\begin{array}{l}\text { Algorithm }(\text { nitrate }+ \text { nitrite }+ \\
\text { ammonia }+ \text { organic-N) }\end{array}$ \\
\hline Total saxitoxins, recoverable & 89003 & OGRL & - & 0.02 & $\mu \mathrm{g} / \mathrm{L}$ & Graham and others (2010) \\
\hline Transparency, water, in situ & 00078 & (field) & - & - & $\mathrm{m}$ & $\begin{array}{l}\text { U.S. Environmental Protection } \\
\text { Agency (1997b) }\end{array}$ \\
\hline Zinc, water, filtered & 01090 & NWQL & $7440-66-6$ & 1.4 & $\mu \mathrm{g} / \mathrm{L}$ & Garbarino and others (2006) \\
\hline
\end{tabular}


Table 2. Analytical information for physical properties and chemical constituents measured in samples of water and bed sediments collected in the Albemarle Sound and tributaries, 2012-14.-Continued

[NWIS, National Water Information System. Analyzing laboratory: NWQL, National Water Quality Laboratory; OGRL, Organic Geochemistry Research Laboratory (USGS); TA, TestAmerica Laboratories, Inc. CAS RN, Chemical Abstract Services Registry Number. Abbreviations used in units: $\mathrm{CaCO}_{3}$, calcium carbonate; ${ }^{\circ} \mathrm{C}$, degree Celsius; $\mathrm{m}$, meter; $\mathrm{mg} / \mathrm{kg}$, milligram per kilogram; mg/L, milligram per liter; mm Hg, millimeter of mercury; N, nitrogen; P, phosphorus; PSS, Practical Salinity Scale; std, standard; $\mathrm{SiO}_{2}$, silicon dioxide; $\mu \mathrm{g} / \mathrm{l}$, microgram per liter; $\mu \mathrm{S} / \mathrm{cm}$, microSiemen per centimeter; Wt $\%$, weight percent. —, not applicable]

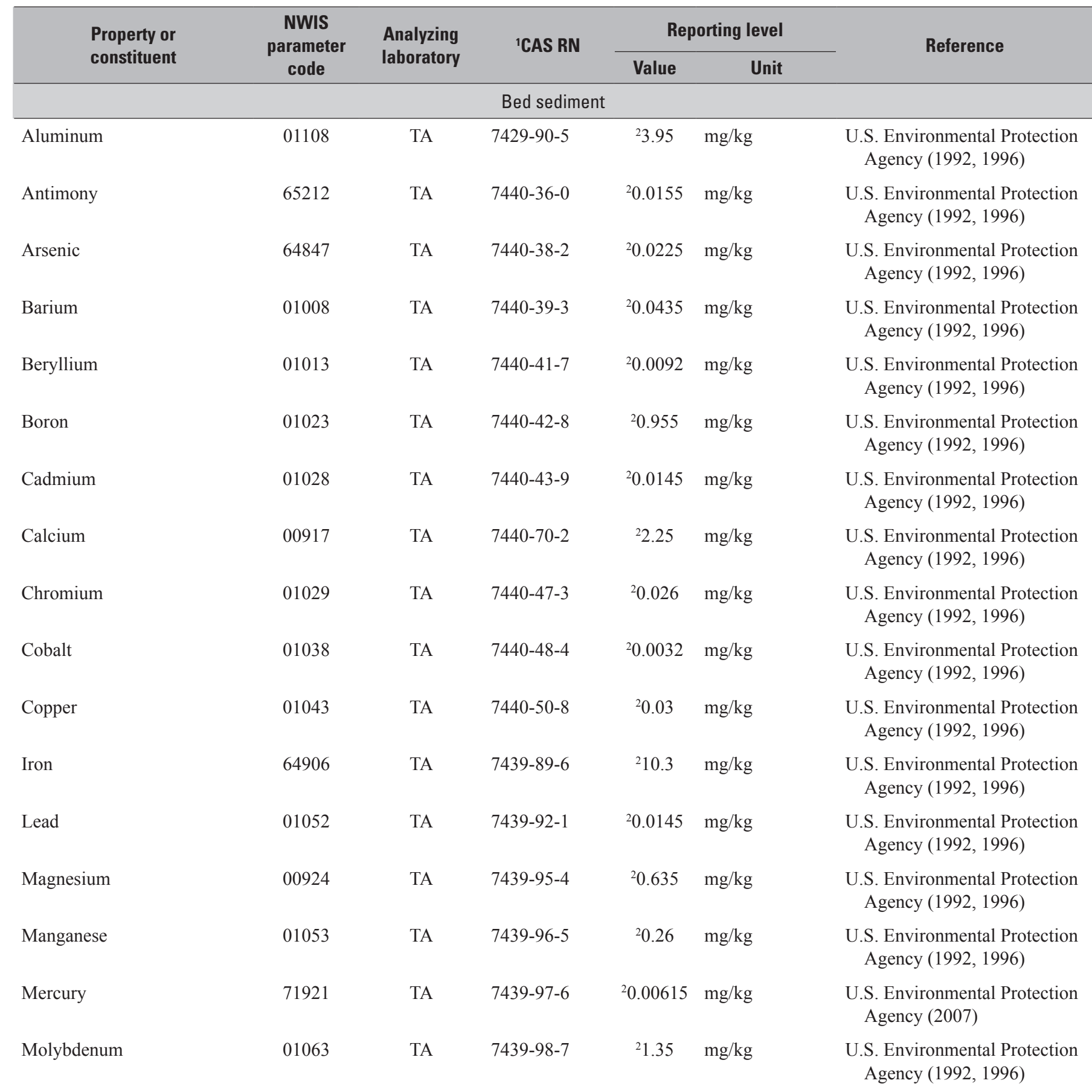


Table 2. Analytical information for physical properties and chemical constituents measured in samples of water and bed sediments collected in the Albemarle Sound and tributaries, 2012-14.-Continued

[NWIS, National Water Information System. Analyzing laboratory: NWQL, National Water Quality Laboratory; OGRL, Organic Geochemistry Research Laboratory (USGS); TA, TestAmerica Laboratories, Inc. CAS RN, Chemical Abstract Services Registry Number. Abbreviations used in units: $\mathrm{CaCO}_{3}$, calcium carbonate; ${ }^{\circ} \mathrm{C}$, degree Celsius; m, meter; $\mathrm{mg} / \mathrm{kg}$, milligram per kilogram; mg/L, milligram per liter; mm Hg, millimeter of mercury; N, nitrogen; P, phosphorus; PSS, Practical Salinity Scale; std, standard; $\mathrm{SiO}_{2}$, silicon dioxide; $\mu \mathrm{g} / 1$, microgram per liter; $\mu \mathrm{S} / \mathrm{cm}$, microSiemen per centimeter; $\mathrm{Wt} \%$, weight percent. —, not applicable]

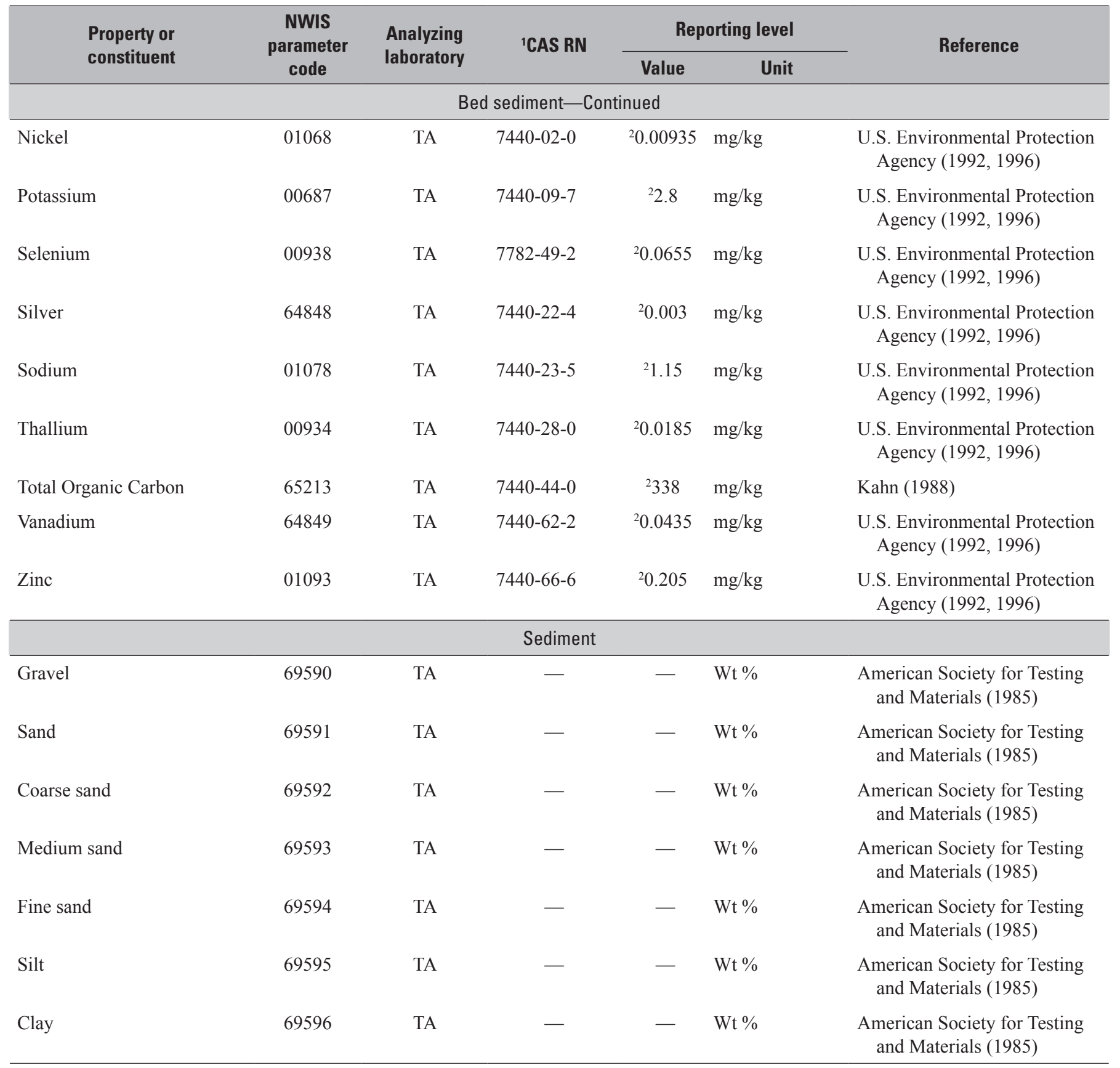

${ }^{1}$ American Chemical Society (2016).

${ }^{2}$ Median method detection levels for the dataset. 
there was little to no bias. For cobalt, 24 percent of the environmental concentrations were within a factor of five of the highest cobalt concentration in a field blank. Cobalt concentrations lower than about $0.86 \mu \mathrm{g} / \mathrm{L}$ in environmental samples should be considered potentially biased high.

Variability of 32 constituent concentrations in water samples was assessed with 9 field replicate sets analyzed at the USGS National Water Quality Laboratory or the Organic Geochemistry Research Laboratory of the USGS Kansas Water Science Center (appendix table 1-1c). A total of 137 replicate sets were analyzed, which is less than 288 sets ( 32 constituents times 9 field replicate sets) because only a subset of constituents was analyzed in each set. Forty-seven replicate sets for 15 constituents had both concentrations below the reporting level, were deemed to be in agreement, and were not discussed further. Nine sets for seven constituents had discordant concentrations with one concentration above and one concentration below the respective reporting level. The concentrations were close to the reporting levels; therefore, these discordant sets were deemed acceptable and were not assessed further.

Relative percent differences (RPD) were computed for the remaining 81 replicate sets where both concentrations were above the reporting levels. The median RPD for the 23 constituents represented in these sets ranged from 1 to 65 percent. Eighteen constituents had median RPDs less than 25 percent, which was considered acceptable and were not discussed further. Five constituents had a median RPD of greater than 25 percent and included iron, cobalt, manganese, total cylindrospermopsins, and total microcystins. For these five constituents, the median absolute concentration difference was calculated and divided by the respective reporting levels to distinguish between small concentration differences near the reporting level (ratio near 1), which were acceptable, compared to large concentration differences well above the reporting level (ratio above 5), which indicated variability that potentially affected the environmental results. Using this approach, the two cyanotoxins had acceptable variability. In contrast, iron, cobalt, and manganese had a ratio of greater than 10 indicating relatively large absolute concentration differences within those replicate sets, which should be considered in any discussion of these constituents.

An interlaboratory assessment of an abbreviated list of constituents was conducted with six sets of field replicates in July 2012 and four sets of split replicates in February 2014 between three laboratories (appendix table 1-1d) in order to evaluate data comparability for potential future data pooling. Field and split replicates of water samples were analyzed for suspended solids and nutrients by both the National Water Quality Laboratory and NCDENR and were also analyzed for chlorophyll $a$ by both Meritech (for USGS) and NCDENR. Median RPDs for suspended solids and nutrients in the field replicates and split replicates were all less than 25 percent and so were considered acceptable. In contrast, the median RPD for chlorophyll $a$ concentrations was 64 percent and 49 percent for the field and split replicates, respectively. In all cases, chlorophyll $a$ concentrations analyzed by Meritech were lower than those reported by NCDENR (appendix table 1-1a). This negative bias in the USGS database is about $6 \mu \mathrm{g} / \mathrm{L}$ and is in keeping with previous results for chlorophyll $a$ in a round-robin study coordinated by the DWR Laboratory Certification Program of NCDENR (unpublished data). Chlorophyll $a$ concentrations in the replicate samples ranged between 5.6 and $20 \mu \mathrm{g} / \mathrm{L}$ (appendix table 1-1a), whereas about 35 percent of the concentrations presented in this report exceeded that range. Unpublished interlaboratory replicate data collected on another brackish water system in late 2014 included concentrations in the higher range of the present study. A negative median bias was again observed though was about four times larger than that seen for the lower range. Because these replicates were analyzed almost a year after the last samples in the present study were analyzed, and because phytoplankton assemblages between Albemarle Sound and the other brackish system might differ, the relevance of these unpublished data to the present study is uncertain. Although chlorophyll $a$ values determined by Meritech were within two standard deviations of the mean in the 2012 roundrobin study, any interpretation of the chlorophyll $a$ results should include this negative bias that is potentially larger for higher concentrations.

Quality assurance for biological constituents addressed taxonomic identification and data entry (North Carolina Department of Environment and Natural Resources Division of Water Quality, 2003). Quality assurance for quantitative procedures (cell and unit counts and biovolumes) are currently (2014) being evaluated. The staff estuarine phycologist maintains a reference taxa list that conforms to a master reference taxa list and contains specific information for each classification including complete name, reference, size range, biovolume, habitat, and digital image. Variability was assessed using seven field replicate sets (appendix table 1-2b). The RPDs were computed for total phytoplankton density in cells per milliliter (cells $/ \mathrm{mL}$ ) (median $=38$ percent; range $=10$ to 94 percent), total phytoplankton biovolume in cubic millimeters of biomass per cubic meter of water (median $=62$ percent; range $=28$ to 86 percent), and cyanobacteria density in cells $/ \mathrm{mL}$ (median $=38$ percent; range $=8$ to 86 percent). Because random error associated with sampling and enumeration of phytoplankton is considered the only important source of error (Lund and others, 1958), any nonrandomness in the samples can introduce bias. The size and patchiness of phytoplankton communities in natural waters in comparison to sample size and the presence of rare species are two factors that might contribute to relatively large variability between field replicates collected for phytoplankton metrics. The variability of phytoplankton metrics as shown by these field replicates should be considered when discussing the environmental results.

Bias of 25 elements in bed sediments was assessed with two matrix spikes, whereas bias for mercury in bed sediment was assessed with one matrix spike (appendix table 1-3b). The contract laboratory (TestAmerica Laboratories, Inc.) calculated all recoveries as well as provided all data quality remarks on 
the recoveries. Matrix spikes were split samples in which one was fortified with a known mass of the constituents. Recovery could not be assessed in seven elements spiked out of range (original sample concentration more than four times the matrix spike concentration) including aluminum, chromium, iron, lead, manganese, vanadium, and zinc. For elements within the correct spiking range, recoveries were acceptable (80 to 120 percent) for seven elements (beryllium, boron, cadmium, mercury, silver, sodium, and thallium). For six other elements (barium, calcium, copper, magnesium, nickel, and potassium), the recovery was acceptable in only one of the two spiked samples. Low concentrations between the detection and reporting level that were estimated, or control limit exceedances, prevented assessment of recovery of four elements including antimony, arsenic, cobalt, and selenium. Finally, total organic carbon recovery was not assessed by matrix spiking. In contrast to the matrix spikes, recovery of all elements in blank matrix spikes (except iron in one spike) was acceptable (appendix table 1-3b). These blank matrix spikes are spike solutions added to Teflon chips in the case of the metals or a solution of potassium hydrogen phthalate added to reagent for total organic carbon. Better recovery in blank matrix spikes compared to that in matrix spikes isolates the bed sediment matrix, as opposed to the analytics, as the source of poor or unknown bias.

Variability of elemental concentrations in bed sediment was investigated with a field replicate (two sets of jars filled sequentially from two separate homogenized samples), a split replicate (two sets of jars filled concurrently from one homogenized sample), and two analytical duplicates (two sets of dried, homogenized sediment samples from the same jar) (appendix tables 1-3a and 1-3c). Only one analytical duplicate was analyzed for mercury. These nested replicates can isolate variability associated with just the analysis (analytical duplicates) from the variability associated with the analysis plus handling steps (split replicate) within the overall variability (analysis, handling, and sample collection) as shown by the field replicate. The RPD for most elements in bed sediments in the field replicate, split replicate, and analytical duplicate "A" (collected on October 15, 2012) were less than 25 percent and were considered acceptable (appendix table 1-3c). Only two elements in the field replicate, boron, and total organic carbon, had RPDs that exceeded 25 percent. For most elements, RPDs for the field replicate and split replicate were similar and were generally higher that RPDs for analytical duplicate "A." Thus, the overall variability from the field replicate was controlled largely by the handling step of collecting subsamples from a homogenized wet sample that the split replicate reflects. Compared to this handling step, even the collection of two separate samples in succession (field replicate) does not add much more to the overall variability for most elements. The second analytical duplicate ("B") collected on October 17, 2012, was more variable with RPDs of about 30 to 40 percent for most elements and more than 100 percent for arsenic (appendix table 1-3c). Because the analytical variability is nested within the handling and overall variability, and the overall variability determined from the field replicates was acceptable for most elements, it seems likely that this one analytical duplicate set was not representative of the true analytical precision.

\section{Calculation of Summary Statistics}

Summary statistics for all water-quality and bed sediment-quality data collected as part of the Albemarle Sound demonstration project were computed using the "censSumStat" function in the R package smwrQW (Lorenz, 2015) or the summary statistics option available in the NWIS WaterQuality System, Version 5.0 program (Dupré and others, 2013). Summary statistics were computed using the log of the regression order on statistics ( $\log$ ROS) when datasets contained censored values (Bonn, 2008). An advantage of log ROS is that estimates of mean and standard deviation can be computed. The log ROS method is preferred when samples sizes are small, when there are multiple reporting limits, and when there are frequent censored data reported. Summary statistics were not computed if greater than 80 percent of data values in a dataset were censored. One exception was total nitrogen (TN), which is presented as censored in appendix tables $2-1$ and $3-1$. The TN value exported from NWIS is calculated as the sum of total ammonia plus organic nitrogen and nitrate plus nitrite. These calculated $\mathrm{TN}$ values are reported as censored if at least one of the measured values, usually nitrate plus nitrite, is censored. Because total ammonia plus organic nitrogen concentrations were above the reporting level and accounted for at least 90 percent of $\mathrm{TN}$ in all samples, simple substitution of the censored values was used in calculating the summary statistics for TN.

\section{Occurrence and Distribution of Constituents in Water}

Two distinct water-quality datasets for the project are presented: (1) Water-quality synoptic, 2012 containing data from July through August 2012 collected at representative riverine and estuarine locations throughout the study area and (2) water-quality monthly sampling, 2013-14 containing data from March 2013 through February 2014 collected in selected embayments to describe seasonal variability in the Yeopim, Little, and North Rivers and the Currituck and Roanoke Sounds.

\section{Water-Quality Synoptic, 2012}

Water-quality samples were collected 1-2 times at 34 sites during the summer of 2012. Results for field, chemical, and biological data collected in 2012 are in appendix 2 (appendix table 2-1, constituents in water samples collected in Albemarle Sound and tributaries, 2012; appendix table 2-2, phytoplankton community cell counts and biovolumes in 
samples collected in Albemarle Sound and tributaries, 2012; appendix table 2-3, water column chemical and physical profiles collected in Albemarle Sound and tributaries, 2012; and appendix table 2-4, transparency and meteorology data collected in Albemarle Sound and tributaries, 2012. Summary statistics including mean, standard deviation, minimum, median, and maximum values are reported for all waterquality data collected (table 3).

Sample results were compared to water-quality standards and guidelines (hereafter referred to as thresholds) published by NCDENR (2007), EPA (2014), and the World Health Organization (WHO, Chorus and Bartram, 1999) (table 4). A hierarchical approach was used to select thresholds with those for North Carolina selected preferentially. If no North Carolina threshold exists for a constituent, thresholds promulgated by EPA or WHO were used. It must be emphasized that individual concentrations that were measured in this study cannot be interpreted as exceedances of published waterquality criteria as defined in sections 303(d) and 305(b) of the Clean Water Act. The State of North Carolina has established protocols to determine assessment of water quality for 303(d) and 305(b) purposes that go beyond the sampling design used in this study. Freshwater and saltwater sometimes have different thresholds and thus are shown separately in table 4.

Among the more than 40 constituents measured during 2012, there are 13 freshwater and 9 saltwater thresholds. Of 440 total analyses, only 68 values (less than 16 percent) exceeded either a freshwater or saltwater threshold or both based on their DWR classification (table 4). Five constituents accounted for 15 values (number of site/date pairs) greater than the respective thresholds including dissolved oxygen (1 instance), filtered aluminum (1 instance), chloride (6 instances), filtered iron (1 instance), and cyanobacteria density (6 instances) at 7 freshwater sites. Note that filtered

Table 3. Summary statistics for water-quality data collected in the Albemarle Sound and tributaries, 2012.

$\left[{ }^{\circ} \mathrm{C}\right.$, degree Celsius; $\mathrm{mg} / \mathrm{L}$, milligram per liter; $\mathrm{N}$, nitrogen; $\mathrm{P}$, phosphorus; $\mathrm{SiO}_{2}$, silica dioxide; $\mu \mathrm{g} / \mathrm{L}$, microgram per liter; $\mu \mathrm{S} / \mathrm{cm}$, microsiemen per centimeter. $<$, less than; - , not calculated]

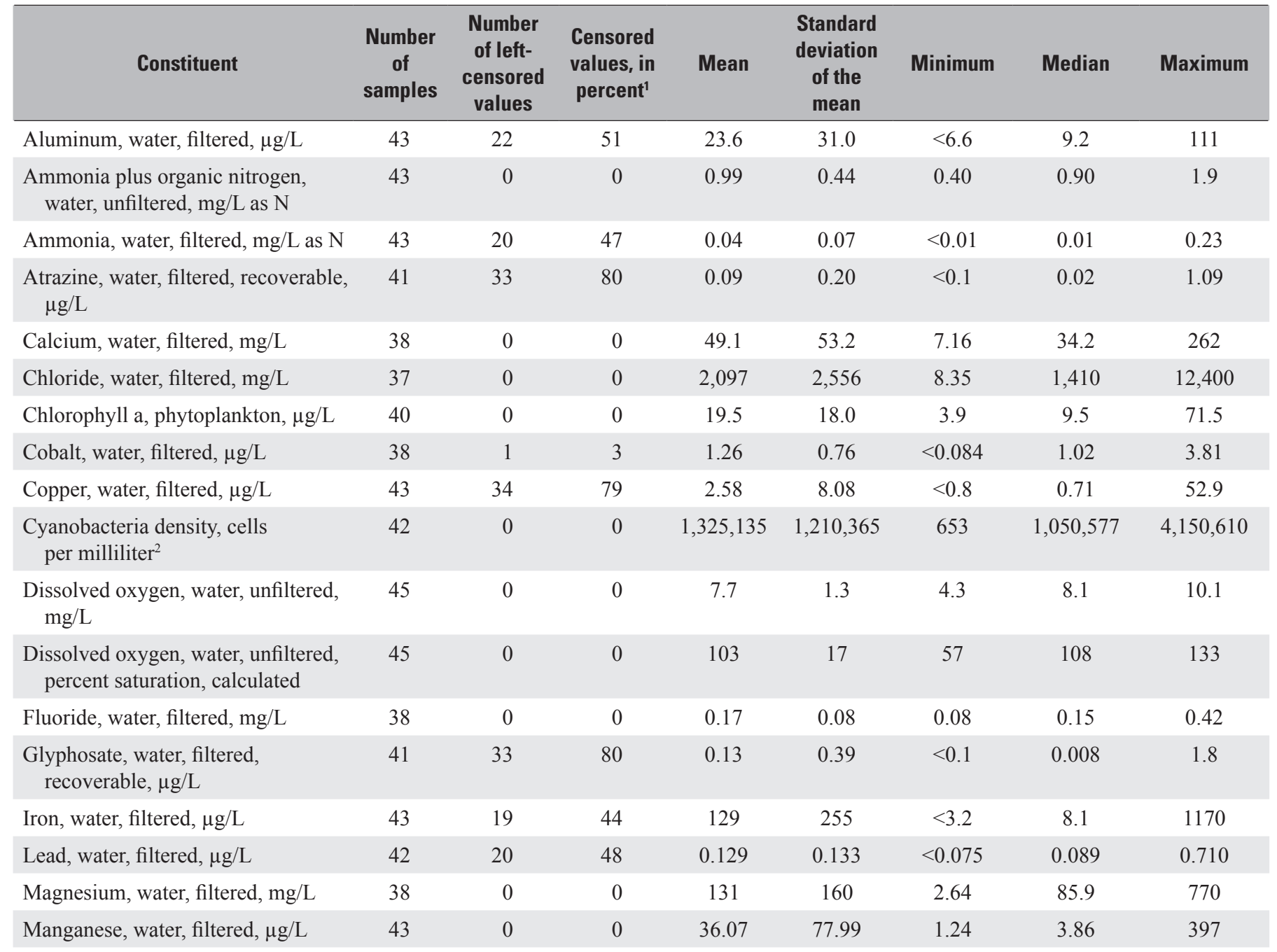


Table 3. Summary statistics for water-quality data collected in the Albemarle Sound and tributaries, 2012.-Continued

$\left[{ }^{\circ} \mathrm{C}\right.$, degree Celsius; $\mathrm{mg} / \mathrm{L}$, milligram per liter; $\mathrm{N}$, nitrogen; $\mathrm{P}$, phosphorus; $\mathrm{SiO}_{2}$, silica dioxide; $\mu \mathrm{g} / \mathrm{L}$, microgram per liter; $\mu \mathrm{S} / \mathrm{cm}$, microsiemen per centimeter. $<$, less than; - , not calculated]

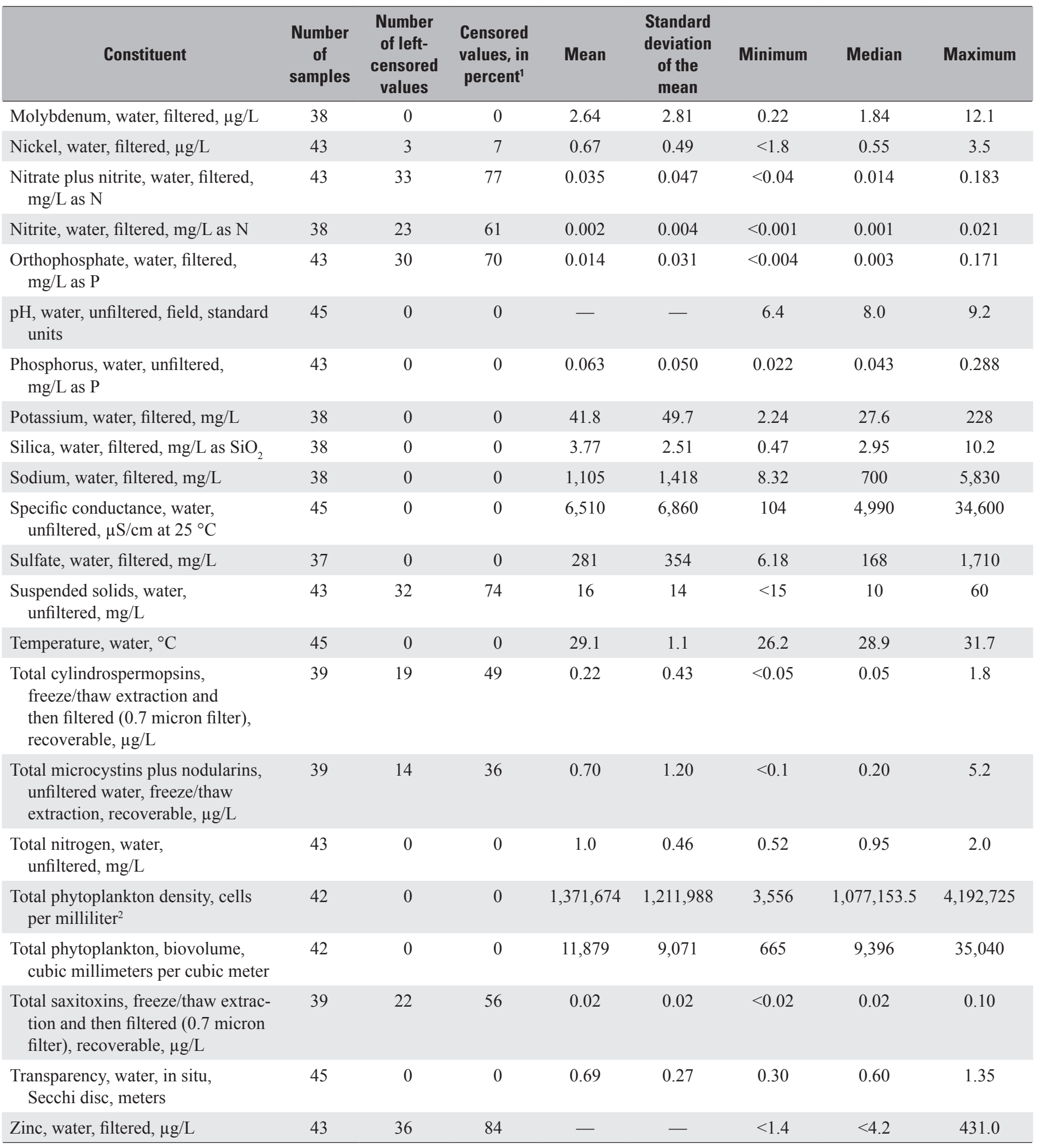

${ }^{1} \log$ regression on statistics was used to compute summary statistics for analytes with left-censored data values. Means and standard deviations were not computed if more than 80 percent of data values within a dataset were censored (Bonn, 2008).

${ }^{2}$ Source of data: North Carolina Department of Environment and Natural Resources Division of Water Resources. These values are computed, reported without rounding, and likely reflect too much precision. Standard rounding procedures are in development. 
Table 4. Comparison of results to water-quality thresholds for samples collected in the Albemarle Sound and tributaries, 2012.

[Units: mg/L, milligram per liter; mL, milliliter; std, standard; $\mu \mathrm{g} / \mathrm{L}$, microgram per liter. References: EPA, U.S. Environmental Protection Agency; NCDENR, North Carolina Department of Environment and Natural Resources. BLM, Biotic Ligand Model; <, less than; —, not applicable]

\begin{tabular}{|c|c|c|c|c|c|c|c|c|c|}
\hline \multirow[b]{2}{*}{ Constituent } & \multirow[b]{2}{*}{ Tyре } & \multicolumn{4}{|c|}{ Freshwater } & \multicolumn{4}{|c|}{ Saltwater } \\
\hline & & $\begin{array}{c}\text { Most } \\
\text { restrictive } \\
\text { water-quality } \\
\text { threshold }\end{array}$ & Reference & $\begin{array}{c}\text { Number } \\
\text { of } \\
\text { exceed- } \\
\text { ances }\end{array}$ & $\begin{array}{l}\text { Sites } \\
\text { (fig. 2) }\end{array}$ & $\begin{array}{c}\text { Most } \\
\text { restrictive } \\
\text { water-quality } \\
\text { threshold }\end{array}$ & Reference & $\begin{array}{c}\text { Number } \\
\text { of } \\
\text { exceed- } \\
\text { ances }\end{array}$ & $\begin{array}{l}\text { Sites } \\
\text { (fig. 2) }\end{array}$ \\
\hline $\begin{array}{c}\text { Dissolved } \\
\text { oxygen }\end{array}$ & Field & $<5 \mathrm{mg} / \mathrm{L}$ & $\begin{array}{l}\text { NCDENR } \\
\quad(2007)\end{array}$ & 1 & 1 & $<5 \mathrm{mg} / \mathrm{L}$ & $\begin{array}{l}\text { NCDENR } \\
\quad(2007)\end{array}$ & 1 & 14 \\
\hline $\begin{array}{l}\text { Aluminum, } \\
\text { filtered }\end{array}$ & Chemical & $87 \mu \mathrm{g} / \mathrm{L}$ & EPA (2014) & 1 & 7 & - & - & - & - \\
\hline $\begin{array}{l}\text { Chloride, } \\
\text { filtered }\end{array}$ & Chemical & $230 \mathrm{mg} / \mathrm{L}$ & EPA (2014) & 6 & $\begin{array}{c}2,3,4 \\
\text { and } 9\end{array}$ & - & - & - & - \\
\hline Copper, filtered & Chemical & ${ }^{1} \mathrm{BLM}$ & EPA (2014) & 0 & - & $3.1 \mu \mathrm{g} / \mathrm{L}$ & EPA (2014) & 3 & 10,16 , and 30 \\
\hline $\begin{array}{l}\text { Fluoride, } \\
\text { filtered }\end{array}$ & Chemical & $1.8 \mathrm{mg} / \mathrm{L}$ & $\begin{array}{l}\text { NCDENR } \\
(2007)\end{array}$ & 0 & - & - & - & - & - \\
\hline Iron, filtered & Chemical & $1,000 \mu \mathrm{g} / \mathrm{L}$ & EPA (2014) & 1 & 1 & - & - & - & - \\
\hline Lead, filtered & Chemical & ${ }^{2} 2.5 \mu \mathrm{g} / \mathrm{L}$ & EPA (2014) & 0 & - & $8.1 \mu \mathrm{g} / \mathrm{L}$ & EPA (2014) & 0 & - \\
\hline Nickel, filtered & Chemical & ${ }^{2} 52 \mu \mathrm{g} / \mathrm{L}$ & EPA (2014) & 0 & - & $8.2 \mu \mathrm{g} / \mathrm{L}$ & EPA (2014) & 0 & - \\
\hline Zinc, filtered & Chemical & ${ }^{2} 120 \mu \mathrm{g} / \mathrm{L}$ & EPA (2014) & 0 & - & $81 \mu \mathrm{g} / \mathrm{L}$ & EPA (2014) & 1 & 29 \\
\hline $\begin{array}{l}\text { Cyanobacteria } \\
{\text { (density })^{3}}^{\text {den }}\end{array}$ & Biological & $\begin{array}{l}100,000 \\
\text { cells } / \mathrm{mL}\end{array}$ & $\begin{array}{c}\text { Chorus and } \\
\text { Bartram } \\
\text { (1999) }\end{array}$ & 5 & $\begin{array}{l}3,4, \\
\text { and } 9\end{array}$ & $\begin{array}{l}100,000 \\
\text { cells } / \mathrm{mL}\end{array}$ & $\begin{array}{c}\text { Chorus and } \\
\text { Bartram } \\
(1999)\end{array}$ & 27 & $\begin{array}{c}8,11-13, \\
15-20, \text { and } \\
22-33\end{array}$ \\
\hline
\end{tabular}

${ }^{1}$ Not calculated because some Biotic Ligand Model parameters were not sampled.

${ }^{2}$ Hardness dependent, assumes a standard hardness of $100 \mathrm{mg} / \mathrm{L}$.

${ }^{3}$ North Carolina Department of Environment and Natural Resources Division of Water Resources (2014). 
iron concentrations, as well as the cyanobacteria density, could be variable, and the number of values higher than the respective thresholds for these constituents might not be accurate. Also, even considering the negative bias in chlorophyll $a$ concentrations, reported values were generally too low at the freshwater sites (range of 3.9 to $11.8 \mu \mathrm{g} / \mathrm{L}$ ) for any potential exceedance of this threshold to have been missed. Thresholds exist for four other constituents (fluoride, filtered lead, filtered nickel, and total microcystins plus nodularins), but there were no values that exceeded the respective concentrations in 2012.

In comparison to the freshwater sites, the saltwater sites had more constituents that exceeded some threshold and many more values higher than the respective thresholds (table 4.). Six constituents accounted for 53 values greater than the respective thresholds (number of site/date pairs) at the saltwater sites including dissolved oxygen (1 instance), $\mathrm{pH}$ (14 instances), chlorophyll $a$ (5 instances), filtered copper (3 instances), filtered zinc (1 instance), and cyanobacteria density (29 instances). Note that the negative bias of chlorophyll $a$ concentrations may have precluded the addition of a few more saltwater sites with values that were higher than the threshold for this constituent. Also, the number of values higher than the cyanobacteria density threshold might not be accurate because of the variability associated with these values. Thresholds for three constituents (filtered lead, filtered nickel and total microcystins plus nodularins) had no exceedances. The multiple instances of the cyanobacteria and $\mathrm{pH}$ thresholds being exceeded are hallmarks of eutrophication in estuarine environments (Bricker and others, 2007). Boxplots of constituents that had at least one value higher than a waterquality threshold are shown in figures $3 A-3 C$. For field and chemical properties, freshwater and saltwater samples are plotted together and the separate thresholds are shown.

\section{Field Measurements}

Albemarle Sound is classified primarily as an oligohaline estuary (Riggs and Ames, 2003) with a salinity gradient that runs east to west and north to south with the highest salinity values in the southeast corner of the region. Although the State designates sites as either freshwater or saltwater, a snapshot of profiles collected in summer of 2012 demonstrates that 26 of 34 sites (76 percent) sampled during the summer of 2012 were brackish (fig. 4) with salinity values in the estuary ranging from 0.05 to 21.72 parts per thousand and a median value of 2.67 parts per thousand. The RDDs were generally low, ranged from 0 to 0.69 percent, and varied across the Albemarle Sound study area (appendix table 2-4 and fig. 5). Four sites were vertically homogenous indicated by an RDD of 0 percent. Many sites with near 0 percent for this value may also be categorized as functionally vertically homogenous. The three most highly stratified sites were located in the Chowan River and western Albemarle Sound (sites 2, 3, and 9; fig. 2). Despite their freshwater classification, the RDD at these sites suggests they are tidally influenced, at least at the time of sampling. The wedge of saline water at these sites was associated with low dissolved oxygen concentration. In some cases, for sites that were visited a month apart, density stratification varied by an order of magnitude. For example, site 3 (Chowan River near Edenhouse, N.C.) had an RDD of 0.59 percent in July 2012 and 0.048 percent in August 2012. Overall, weakened density stratification throughout the Albemarle Sound study area is likely a result of wind-driven tidal mixing.

Elevated $\mathrm{pH}$ occurred as a result of photosynthesis during high periods of productivity. Surface $\mathrm{pH}$ ranged from 6.4 to 9.2 standard units with a median of 8.0 standard units. Five of the sites had a surface $\mathrm{pH}$ less than 6.8 and were located at sites receiving freshwater inputs. Sites where $\mathrm{pH}$ exceeded the 8.5 standard unit threshold were located in the northern sections of the middle and eastern Albemarle Sound (fig. 6) in regions where chlorophyll $a$ concentrations and phytoplankton densities were highest (discussed in the "Biological Data" section). Total suspended solids ranged from $<15$ to 60 milligrams per liter $(\mathrm{mg} / \mathrm{L})$ with a median of $10.32 \mathrm{mg} / \mathrm{L}$. Transparency, measured by Secchi depth, ranged from 0.3 to 1.35 meters $(\mathrm{m})$ with a median depth of $0.6 \mathrm{~m}$ and was less than $1 \mathrm{~m}$ in 87 percent of the samples. Transparencies were lowest in the northern sections of the middle and eastern Albemarle, in the upper reaches of incoming rivers, and at Oregon inlet (fig. 7). Low transparencies can result from light being scattered by suspended and sinking sediment and from light being absorbed by phytoplankton pigments, notably chlorophylls, and color, commonly associated with dissolved organic matter (Lee and Rast, 1997). A euphotic depth defined as the depth in which 1 percent of photosynthetically active radiation entering the water remains ranged from 0.81 to $3.65 \mathrm{~m}$ with a median of $1.76 \mathrm{~m}$ for the study area.

\section{Chemical Data}

Elevated levels of nitrogen and phosphorus can cause excess algal growth, degrade aquatic habitats and the aesthetic quality of recreational waters, and decrease dissolved oxygen concentrations (Wetzel, 2001). Nutrients are considered one of the leading causes of water-quality impairment by the EPA (2009). The TN values ranged from 0.52 to $2.0 \mathrm{mg} / \mathrm{L}$ with a median value of $0.95 \mathrm{mg} / \mathrm{L}$. Values were highest in the northern section of the middle and eastern Albemarle in regions (fig. 8) where chlorophyll $a$ concentrations and phytoplankton densities were greatest (discussed in "Biological Data" section). Most of the nitrogen was organically bound (total Kjeldahl nitrogen minus ammonia nitrogen), which generally is assumed to be present mostly within proteins and non-stoichiometric humic and fulvic acids. Organicallybound nitrogen is not immediately available for uptake by primary producers that utilize dissolved inorganic forms of 


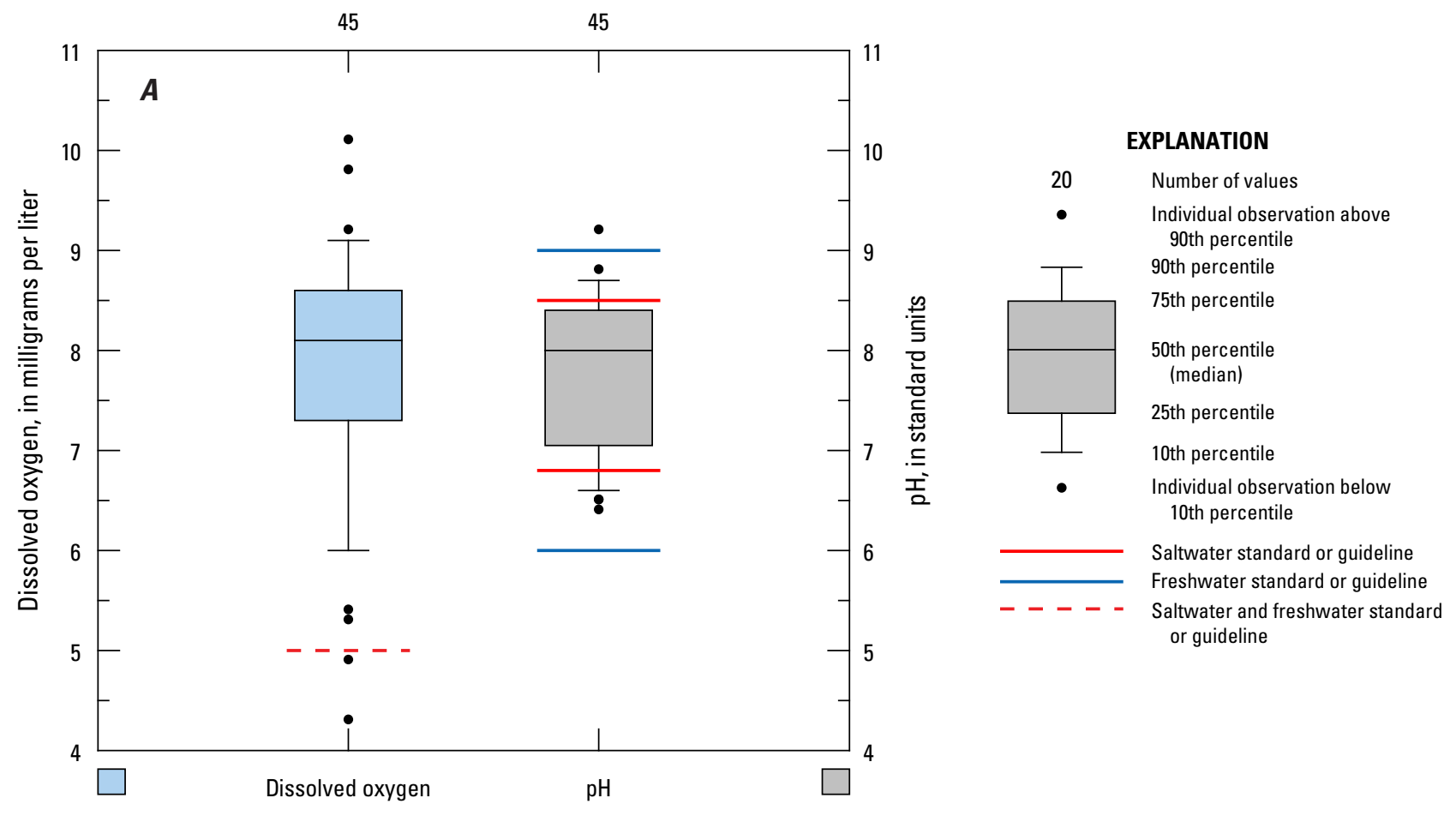

Field parameter

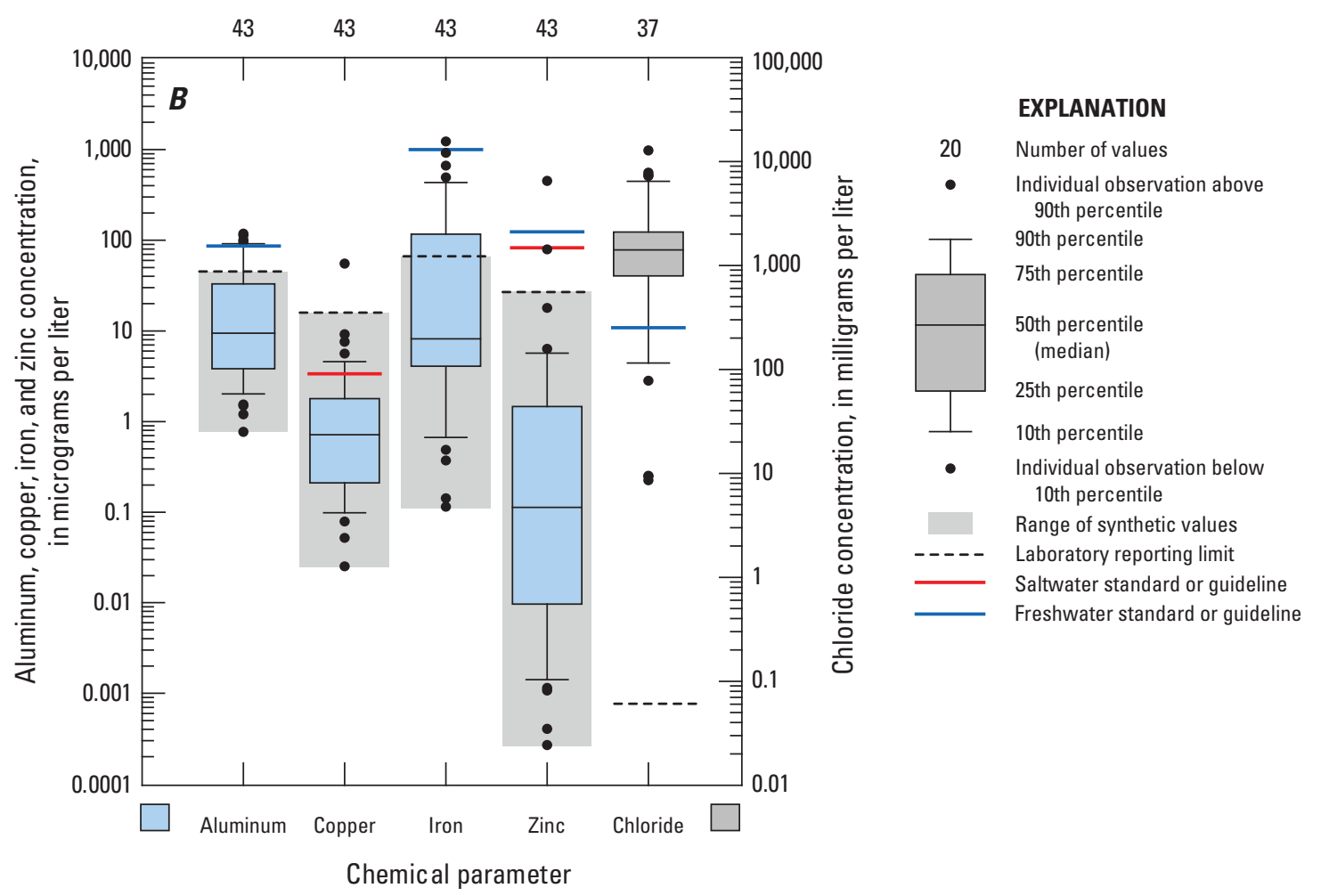

Figure 3. Properties of water samples collected in the Albemarle Sound and tributaries in 2012, grouped into three categories, with concentrations that were greater than a water-quality threshold. $A$, field; $B$, chemical; and $C$, biological. Log on the regression on statistics was used to calculate percentiles for constituents with multiple censoring levels (aluminum, copper, iron, and zinc in figure $3 B$ ). 


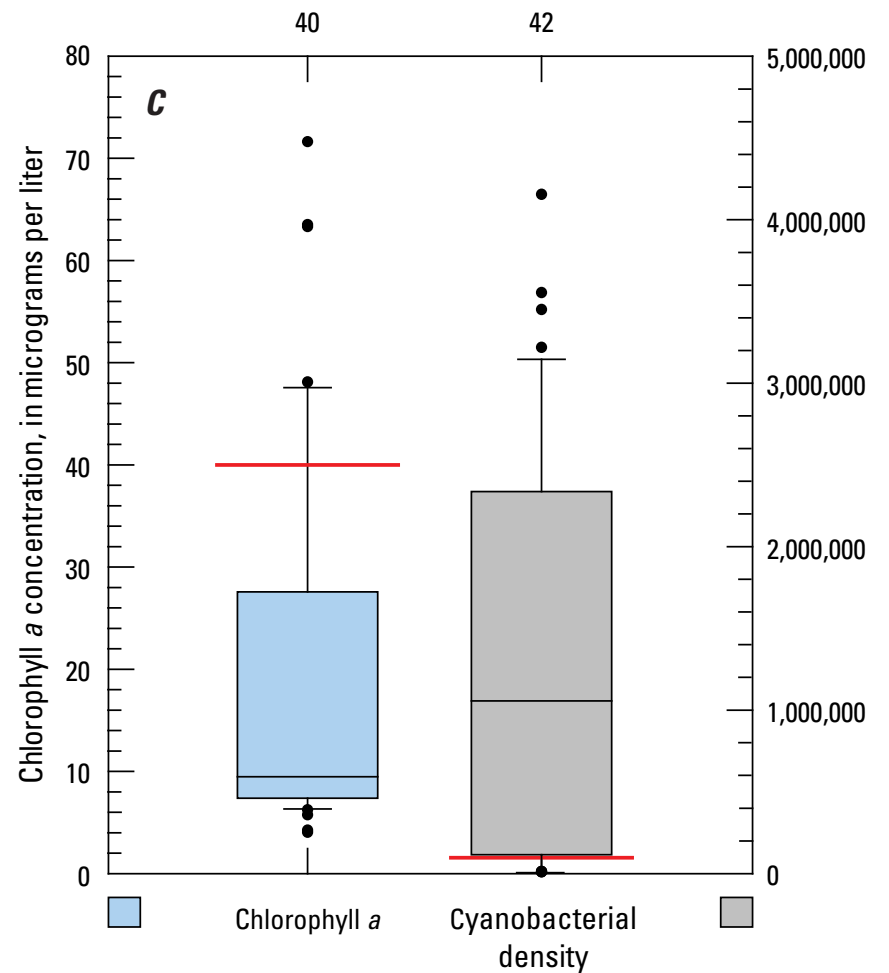

Biological parameter

\section{EXPLANATION}

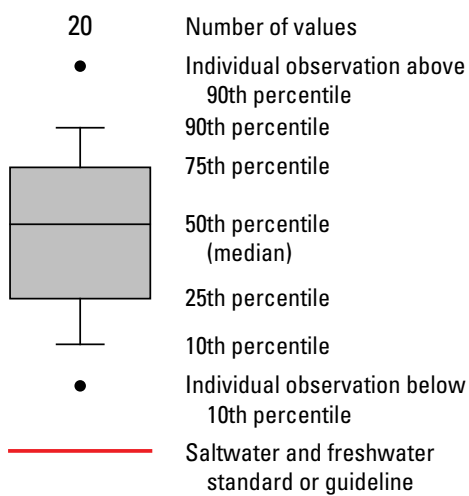

Figure 3. Properties of water samples collected in Albemarle Sound and tributaries in 2012, grouped into three categories, with concentrations that were greater than a water-quality threshold. $A$, field; $B$, chemical; and $C$, biological. Log on the regression on statistics was used to calculate percentiles for constituents with multiple censoring levels (aluminum, copper, iron, and zinc in figure $3 B)$.-Continued

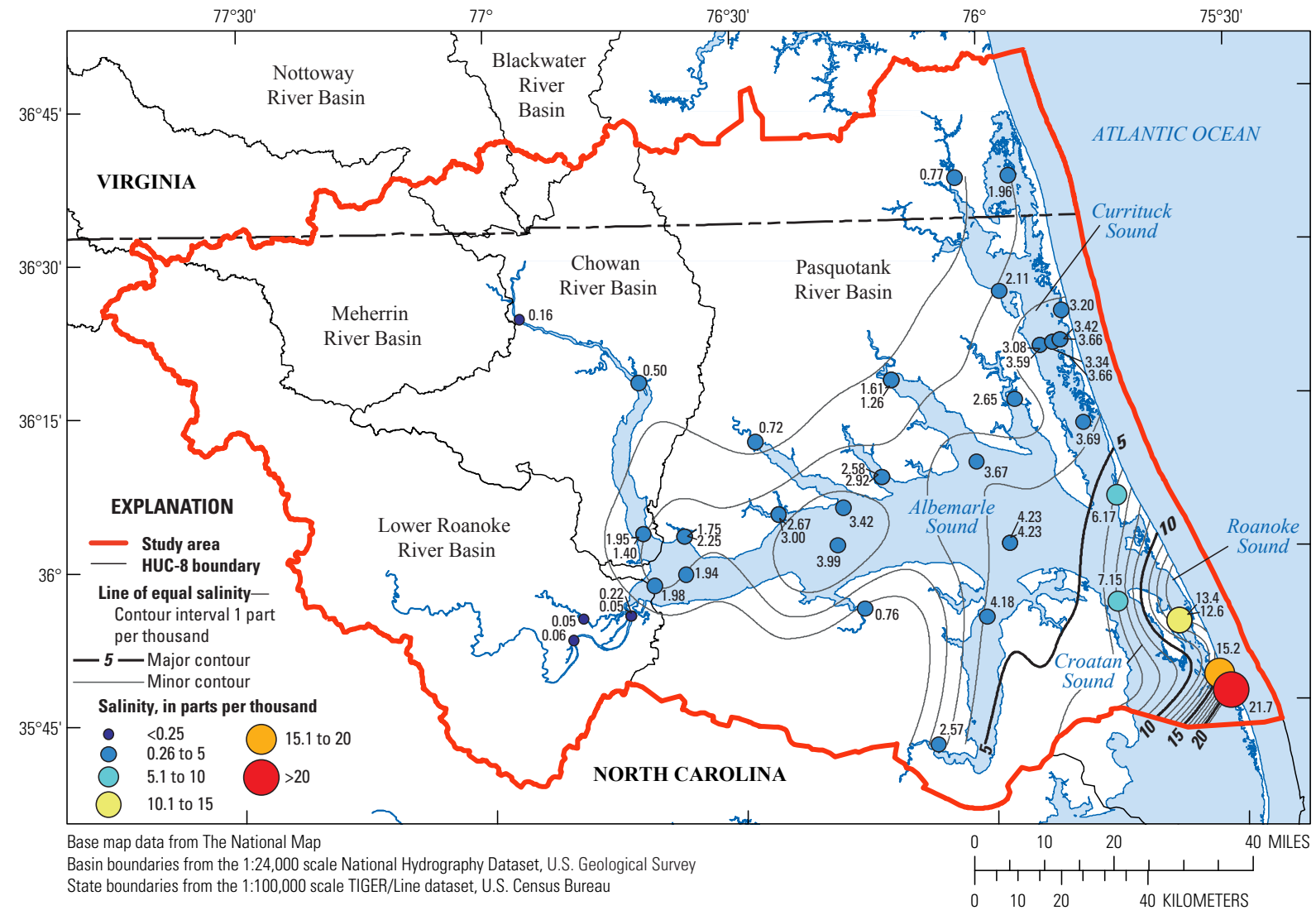

Figure 4. Distribution of salinity measured in the Albemarle Sound and tributaries, 2012. 


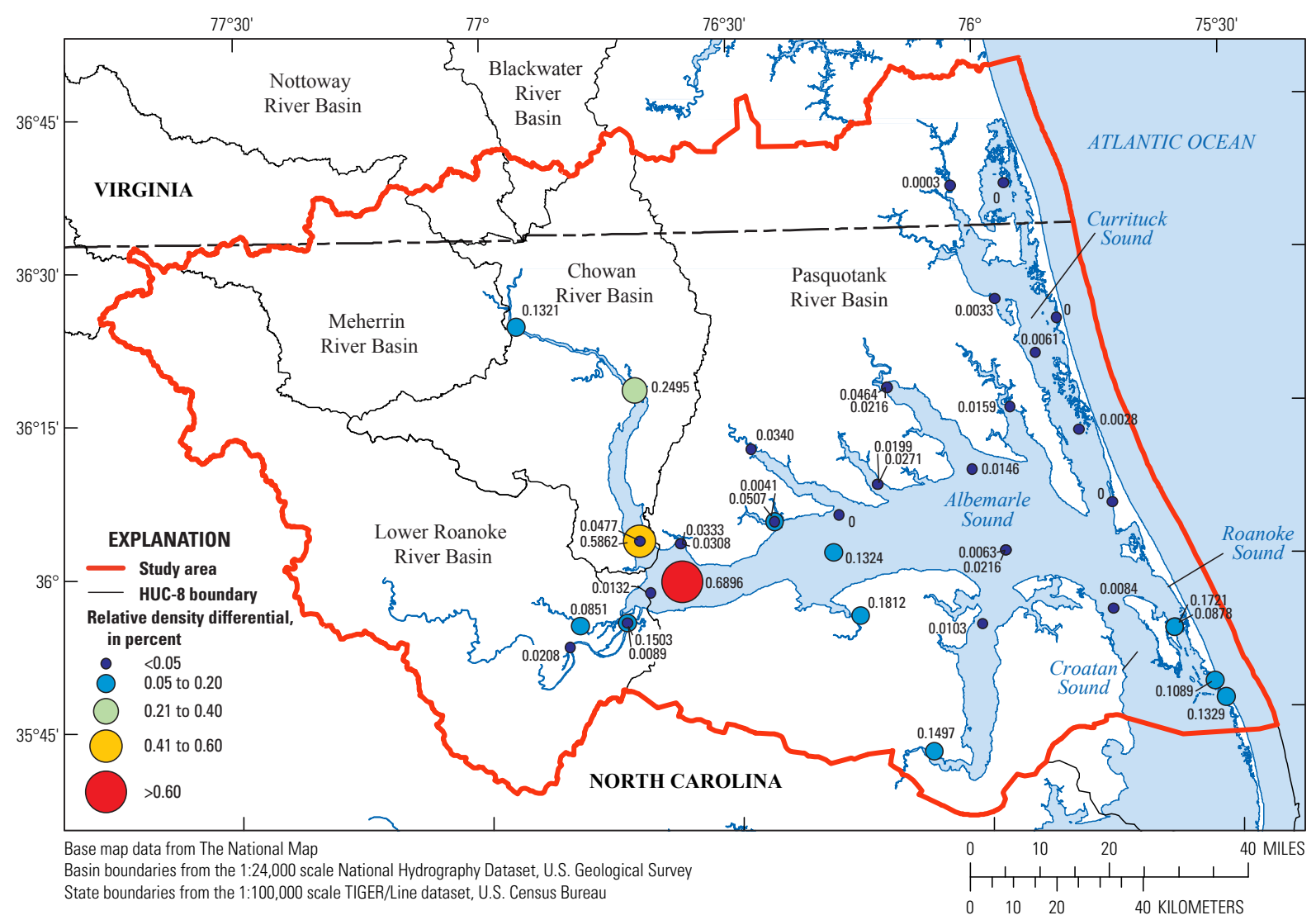

Figure 5. Distribution of relative density differential calculated for sites in the Albemarle Sound and tributaries, 2012.

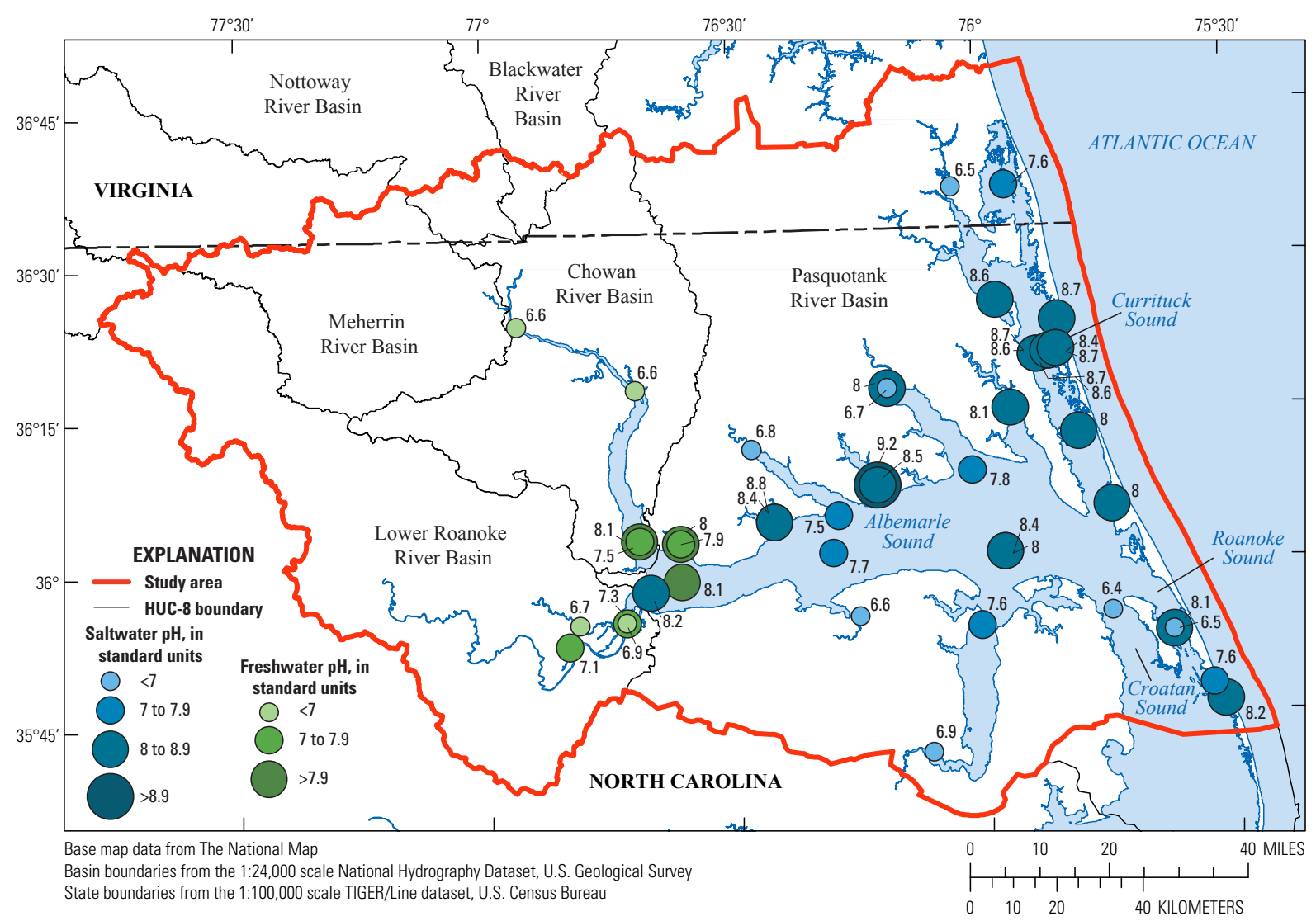

Figure 6. Distribution of field pH values measured in the Albemarle Sound and tributaries, 2012. 


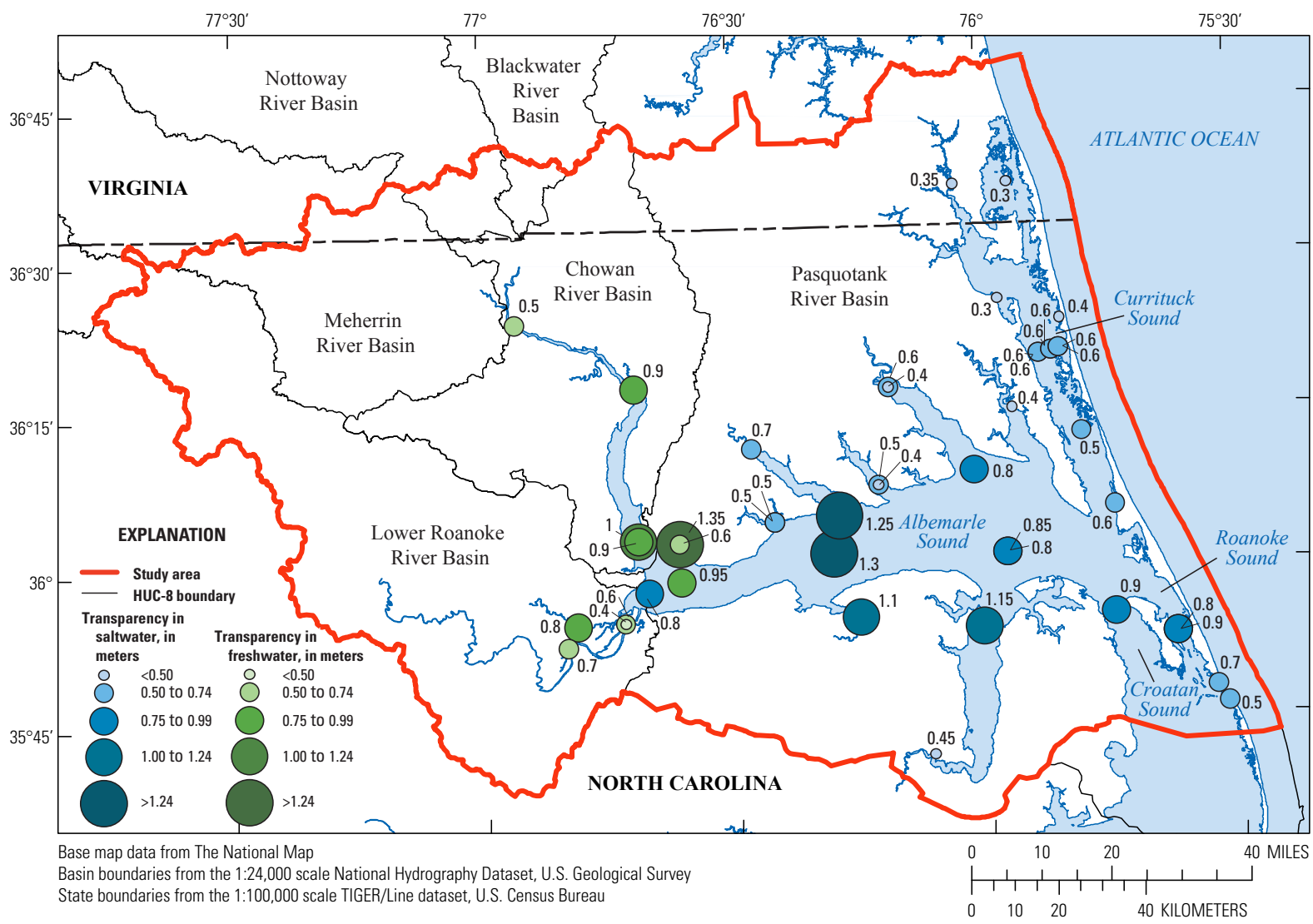

Figure 7. Distribution of field transparency values measured in the Albemarle Sound and tributaries, 2012.

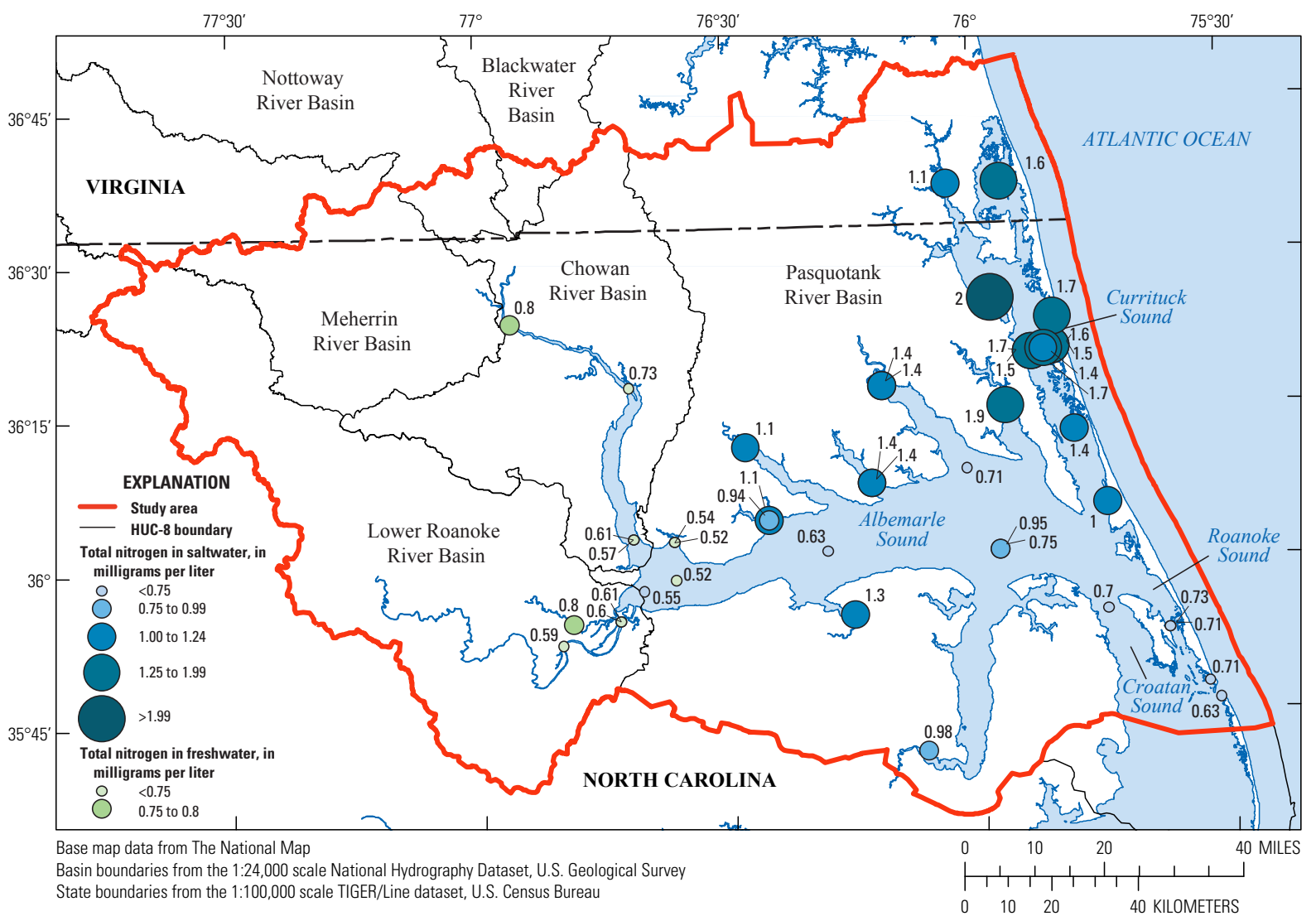

Figure 8. Distribution of total nitrogen values measured in the Albemarle Sound and tributaries, 2012. 
nitrogen. Thus, although TN levels exceeded $1 \mathrm{mg} / \mathrm{L}$, nitrogen could still be a limiting nutrient for phytoplankton growth. Total phosphorus values ranged from 0.022 to $0.288 \mathrm{mg} / \mathrm{L}$ with a median value of $0.043 \mathrm{mg} / \mathrm{L}$. Values were highest in the northern section of the middle and eastern Albemarle (fig. 9) in regions where chlorophyll $a$ concentrations and phytoplankton densities were greatest. Similar to nitrogen, the dissolved portion of total phosphorus was also a small fraction of the total value and thus could be a limiting nutrient for phytoplankton growth.

\section{Biological Data}

Chlorophyll $a$ is a measurement of the main photosynthetic pigment found in plants and algae and is typically used as an estimate of the total phytoplankton biomass (Boyer and others, 2009) though there are known differences in speciesspecific chlorophyll concentrations in cells (Millie and others, 1993). Chlorophyll $a$ values ranged from 3.9 to $71.5 \mu \mathrm{g} / \mathrm{L}$ with a median value of $9.45 \mu \mathrm{g} / \mathrm{L}$. The $40 \mu \mathrm{g} / \mathrm{L}$ threshold was exceeded in 12 percent of the samples, most of which were located in the middle and eastern Albemarle (fig. 10). These values are likely minima given the negative bias of about $6 \mu \mathrm{g} / \mathrm{L}$ noted earlier and the unknown though potentially larger bias for concentrations above about $20 \mu \mathrm{g} / \mathrm{L}$. Elevated levels of chlorophyll $a$ are a sign of eutrophication and can result from nutrient enrichment (Bricker and others, 2007).

Total phytoplankton density ranged from about 3,600 to about 4.2 million cells $/ \mathrm{mL}$ with a median of about 1.08 million cells $/ \mathrm{mL}$ and was highest in the northern, central, and eastern parts of Albemarle Sound (fig. 11). Cyanobacteria, also called blue-green algae, are true bacteria but contain chlorophyll $a$ (among other pigments) that identifies them as photoautotrophs (energy from light and carbon from an inorganic source). Thus, cyanobacteria are typically analyzed as part of phytoplankton community assemblages. Cyanobacteria are the phytoplankton group most commonly associated with harmful algal blooms and toxin production

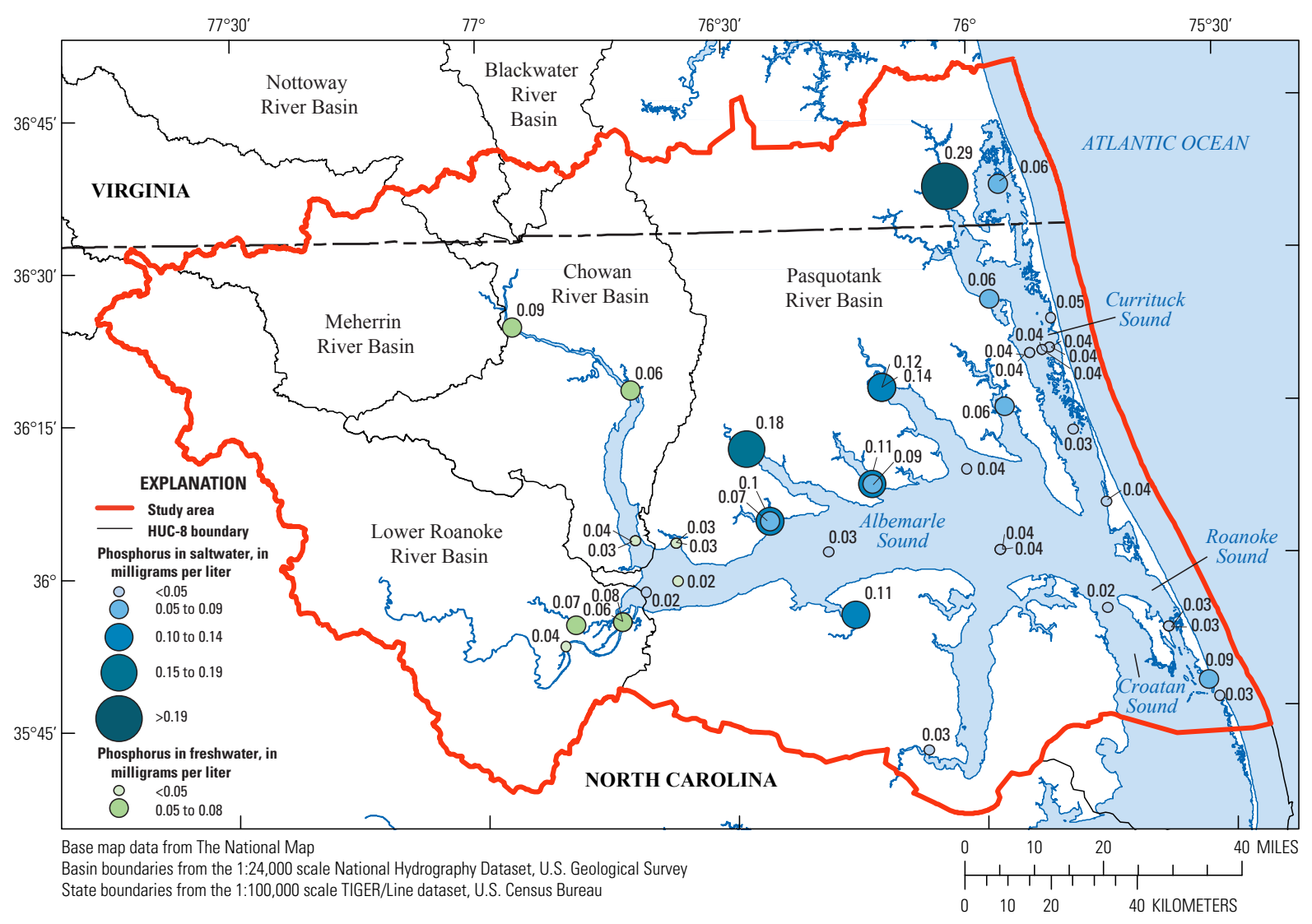

Figure 9. Distribution of phosphorous values measured in the Albemarle Sound and tributaries, 2012. 
in nonmarine systems. Incidences of toxic cyanobacterial blooms are increasing worldwide (Hallegraeff, 1993; Chorus and Bartram, 1999; Paerl and Huisman, 2009; Paerl and Paul, 2012). Cyanobacteria accounted for 12 to 99 percent of the total phytoplankton community in the 42 samples (fig. 11). When total phytoplankton were greater than 100,000 cells $/ \mathrm{mL}$ ( 32 of 42 samples), cyanobacteria accounted for 81 to 99 percent (median $=97$ percent) of the community. Thus, cyanobacteria dominated most communities sampled. Note that the variability of the phytoplankton densities could affect these values as well as those for cyanobacteria.

In general, cyanobacteria cell densities were highest in the northern part of the middle and eastern Albemarle Sound (fig. 12). The WHO provisional guidance for moderate health alert in recreational waters (Chorus and Bartram, 1999) was exceeded in 76 percent of the samples (cyanobacteria greater than 100,000 cells $/ \mathrm{mL} ; 32$ of 42 samples). Although this guidance applies only to freshwater (World Health Organization, 2003) it was applied also to the saltwater sites as a general indication of potential risk. Cyanobacteria can cause a multitude of water-quality concerns and have the potential to produce cyanotoxins that have been implicated in human and animal illness and death (Graham, 2006). Several genera of cyanobacteria were present the Albemarle Sound including Anabaena, Anabaenopsis, Aphanizomenen, Aphanocapsa, Cylindrospermosis, Microcystis, and Pseudoanabaena. All of these have the potential for toxin production (Graham and others, 2008). Potential toxin-producing cyanobacteria genera accounted for varying percentages of the total cyanobacteria and ranged from 0 to 94 percent (median $=54$ percent). Low levels (concentrations near the respective reporting levels) of the cyanotoxins microcystin, saxitoxin, and cylindrospermopsin were found in Albemarle Sound and certain tributaries indicating that they were present, but did not exceed any recommended thresholds. Of the three cyanotoxins, microcystin was most frequently detected (64 percent of analyses) and had the highest median $(0.20 \mu \mathrm{g} / \mathrm{L})$ and maximum $(5.2 \mu \mathrm{g} / \mathrm{L})$ concentrations found (table 3$)$.

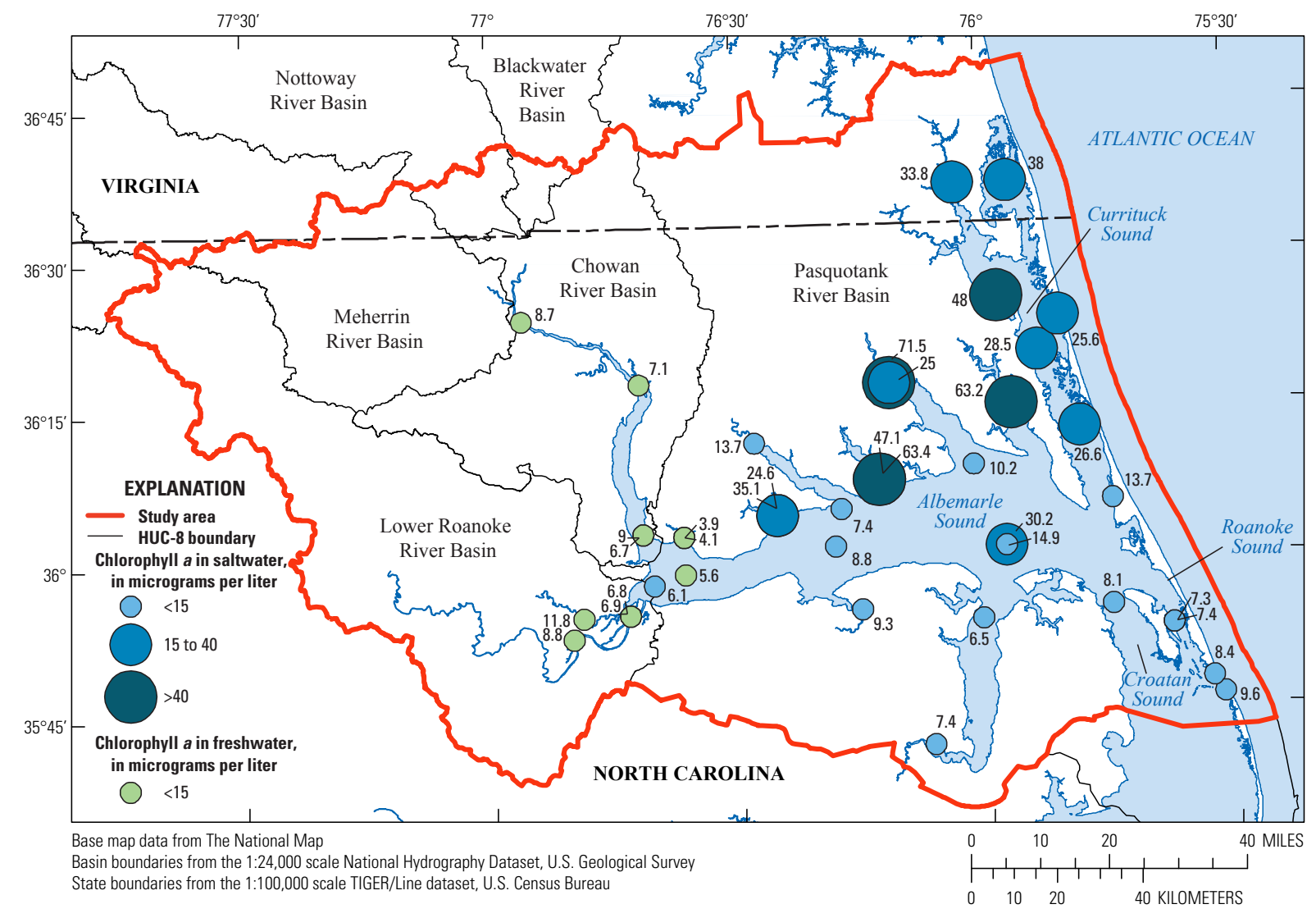

Figure 10. Distribution of chlorophyll a values measured in the Albemarle Sound and tributaries, 2012. 


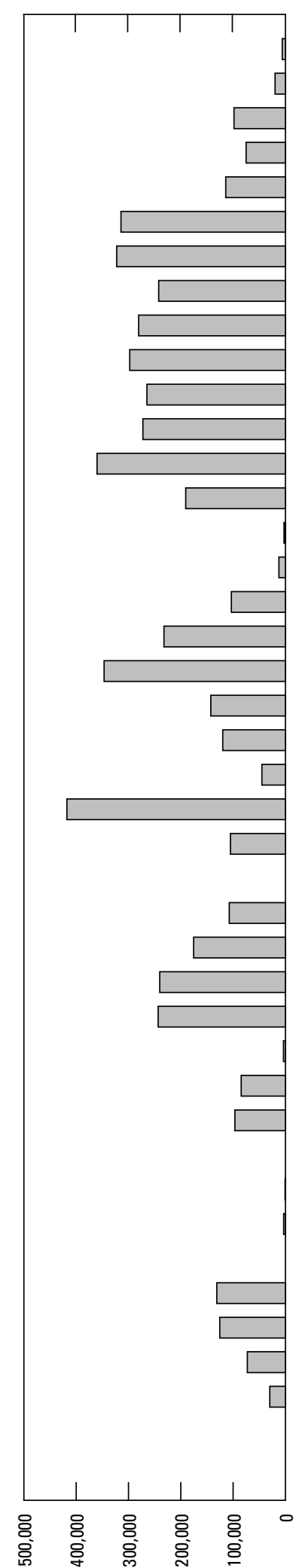

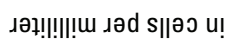

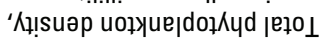

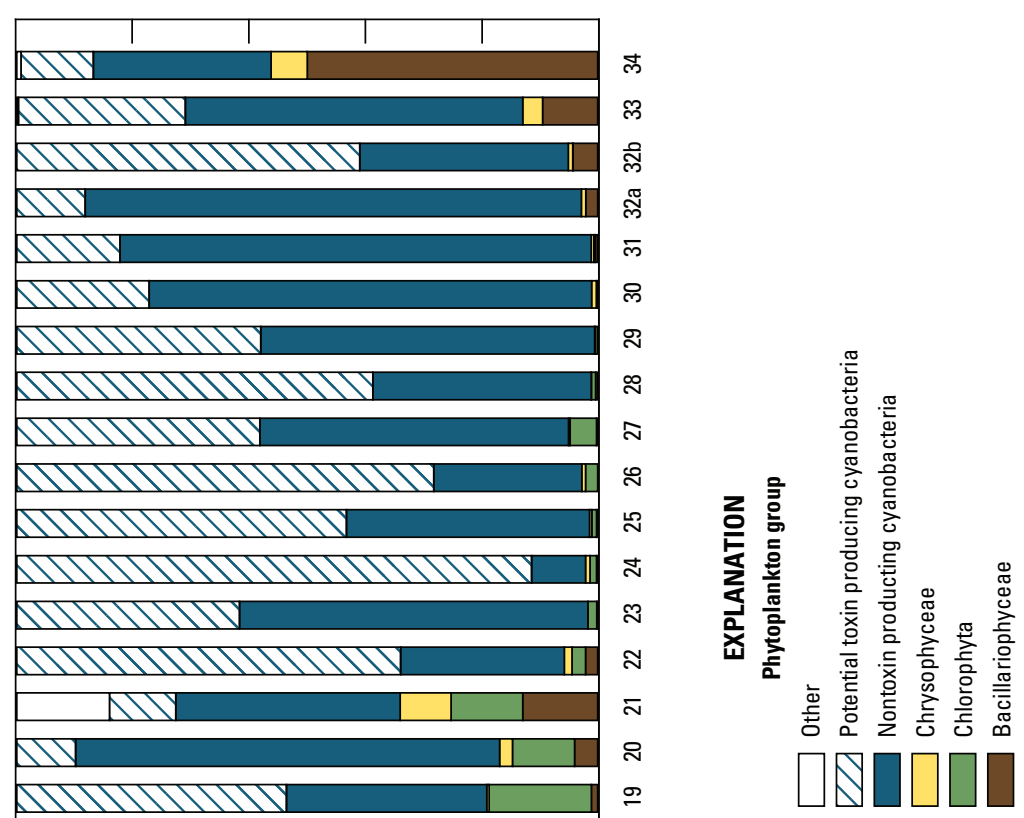

MIIIIIIIIIIII

MIIIIV $\cong$

MIIIII
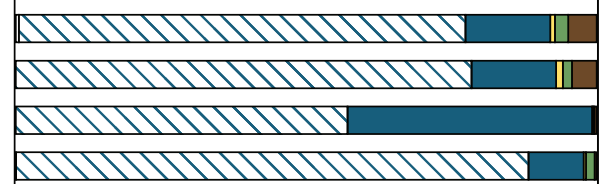

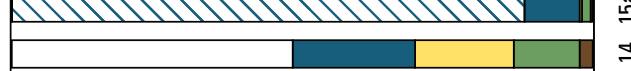

M11/11/11/ $\cong$

MIIIIII

MININY

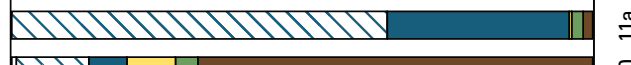

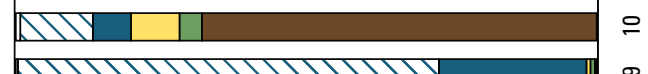

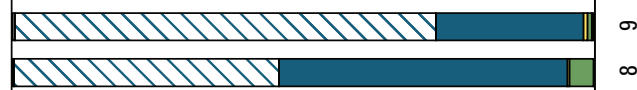

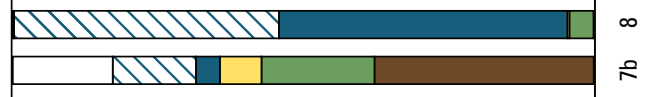

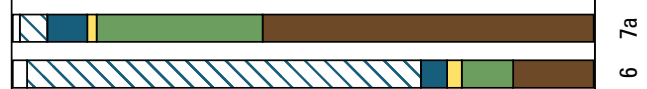

\begin{tabular}{|l|l|l|}
\hline RIIIV & & \\
\hline
\end{tabular}

MIIV
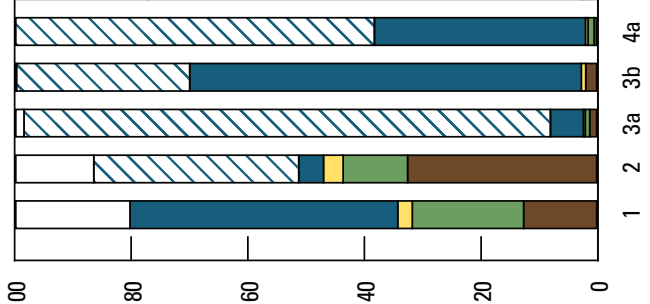

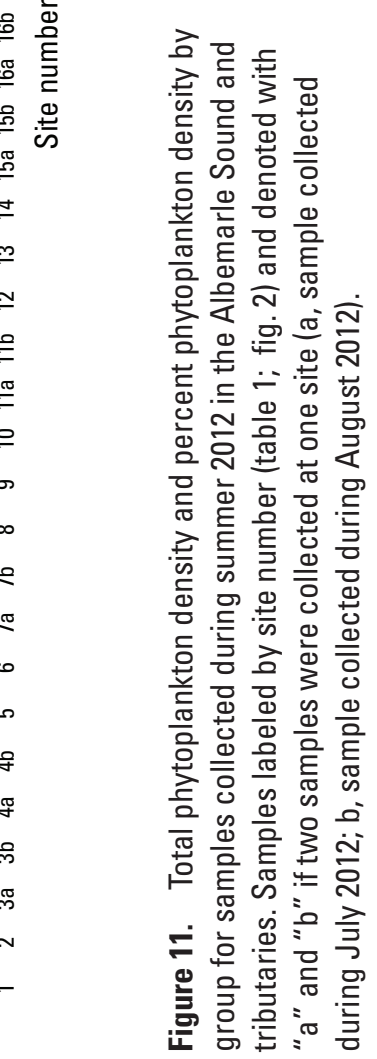




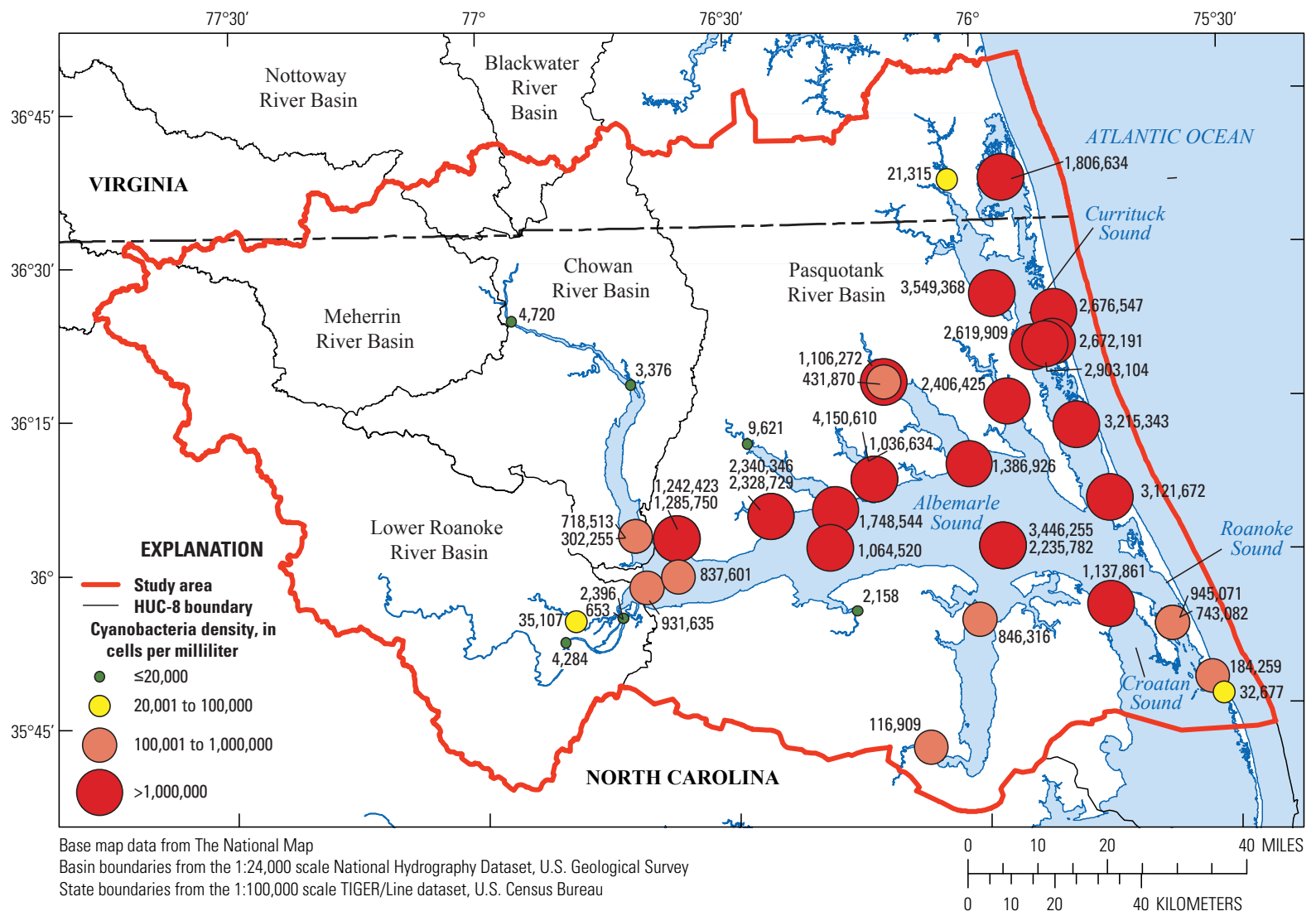

Figure 12. Distribution of cyanobacteria density measured in the Albemarle Sound and tributaries, 2012.

\section{Water-Quality Monthly Sampling, 2013-14}

Data from the 2012 synoptic were used to refine the sampling design to focus on the factors commonly associated with the causes or symptoms of eutrophication in 2013-14. Monthly samples for properties used to assess eutrophication (nutrients, phytoplankton, and so on) were collected at eight saltwater sites in the Currituck Sound, North River, Yeopim River, and Little River embayments where cyanobacteria cell counts were high in 2012 (fig. 2). This design complemented the State current monitoring network in the Albemarle Sound by collecting additional seasonal data on nutrient and phytoplankton occurrence and distribution in embayments that currently (2015) are not routinely monitored by the State ambient monitoring program. In addition, analyses of phytoplankton, cyanotoxins, and pesticides were added at four sites within the DWR ambient monitoring program. Results for water samples collected by the USGS between March 2013 and February 2014 are in appendix 3 (table 3-1, all constituents in water samples collected in Albemarle Sound and tributaries, 2013-14; table 3-2, phytoplankton community cell counts and biovolumes in samples collected in Albemarle Sound and tributaries, 2013-14; table 3-3, water column chemical and physical profiles collected in Albemarle Sound and tributaries, 2013-14; and table 3-4, transparency and meteorological data collected in Albemarle Sound and tributaries, 2013-14). Summary statistics (that is, mean, standard deviation, minimum, median, and maximum values) are reported for all data collected (table 5).

Sample results were compared to water-quality thresholds from NCDENR (2007) and WHO (Chorus and Bartram, 1999) and are presented in table 6. Five of the 25 constituents had thresholds. Of the 337 values for these constituents, only 50 (less than 15 percent) were above some threshold during the 2013-14 sampling period including $\mathrm{pH}$ (15 instances), chlorophyll $a$ (8 instances), total microcystins plus nodularins ( 1 instance), and cyanobacteria density (26 instances). All of these constituents except the cyanotoxins had values greater than the respective thresholds in samples collected in 2012. The dissolved oxygen threshold was not exceeded in the 2013-14 dataset as it was in the 2012 dataset. Note the negative bias in chlorophyll $a$ concentrations may have resulted in a few less exceedances and the variability of the cyanobacteria densities may have affected the number of exceedances. Boxplots showing seasonal distributions of field and biological properties exceeding thresholds are presented (figs. 13A-13B) and individual properties are discussed. 
Table 5. Summary statistics for water-quality data collected in the Albemarle Sound and tributaries, March 2013 through February 2014.

[Abbreviations: ADDA, 3-amino-9-methoxy-2,6,8-trimethyl-10-phenyldeca-4,6-dienoic acid; ${ }^{\circ} \mathrm{C}$, degree Celsius; ELISA, enzyme-linked immunosorbent assay; $\mathrm{mg} / \mathrm{L}$, milligram per liter; $\mathrm{N}$, nitrogen; $\mathrm{P}$, phosphorus; $\mathrm{SiO}_{2}$, silica dioxide; $\mu \mathrm{g} / \mathrm{L}$, microgram per liter; $\mu \mathrm{S} / \mathrm{cm}$, microsiemen per centimeter. $<$, less than; -, not calculated]

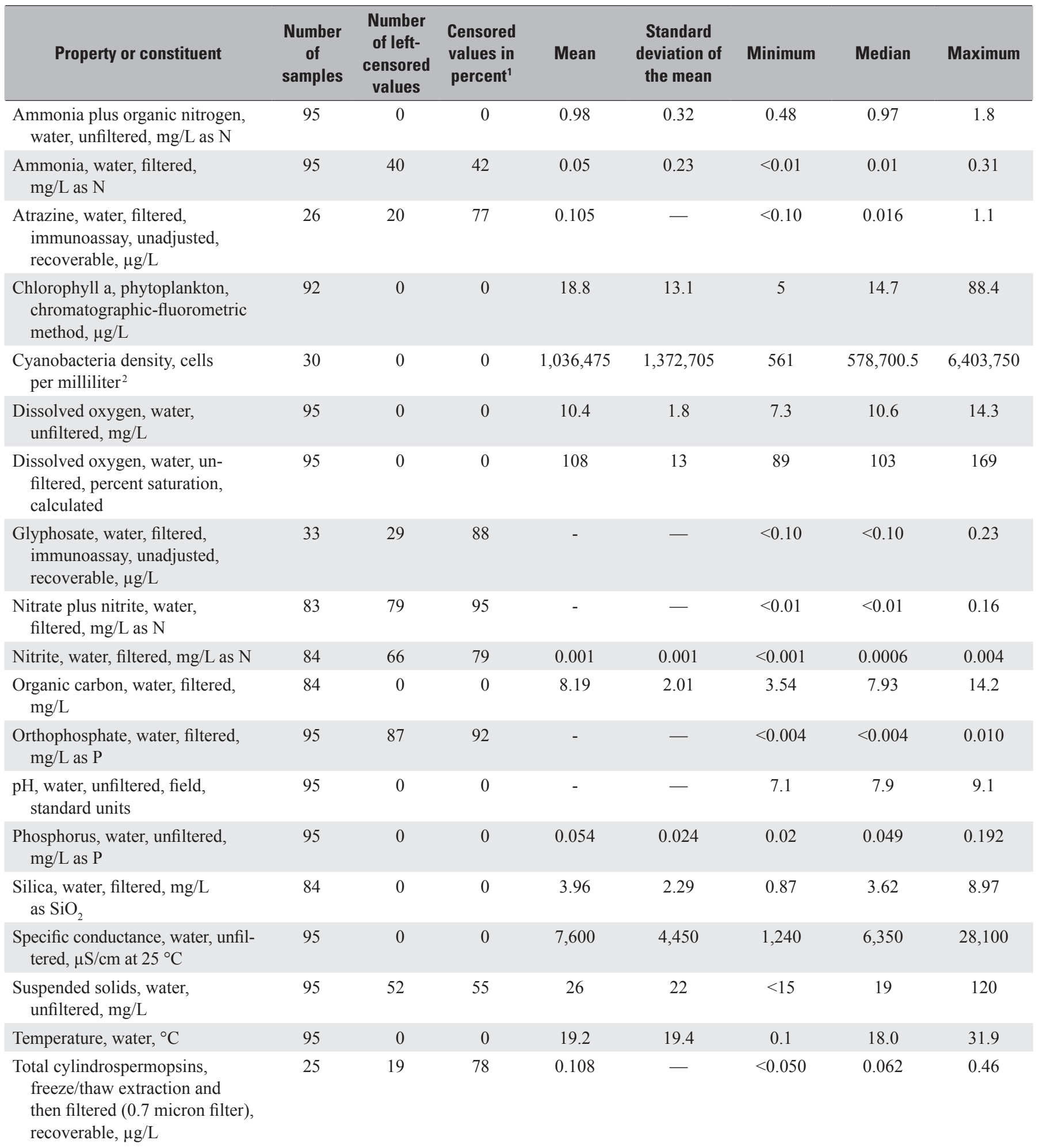


Table 5. Summary statistics for water-quality data collected in the Albemarle Sound and tributaries, March 2013 through February 2014. -Continued

[Abbreviations: ADDA, 3-amino-9-methoxy-2,6,8-trimethyl-10-phenyldeca-4,6-dienoic acid; ${ }^{\circ} \mathrm{C}$, degree Celsius; ELISA, enzyme-linked immunosorbent assay; $\mathrm{mg} / \mathrm{L}$, milligram per liter; $\mathrm{N}$, nitrogen; $\mathrm{P}$, phosphorus; $\mathrm{SiO}_{2}$, silica dioxide; $\mu \mathrm{g} / \mathrm{L}$, microgram per liter; $\mu \mathrm{S} / \mathrm{cm}$, microsiemen per centimeter. $<$, less than; -, not calculated]

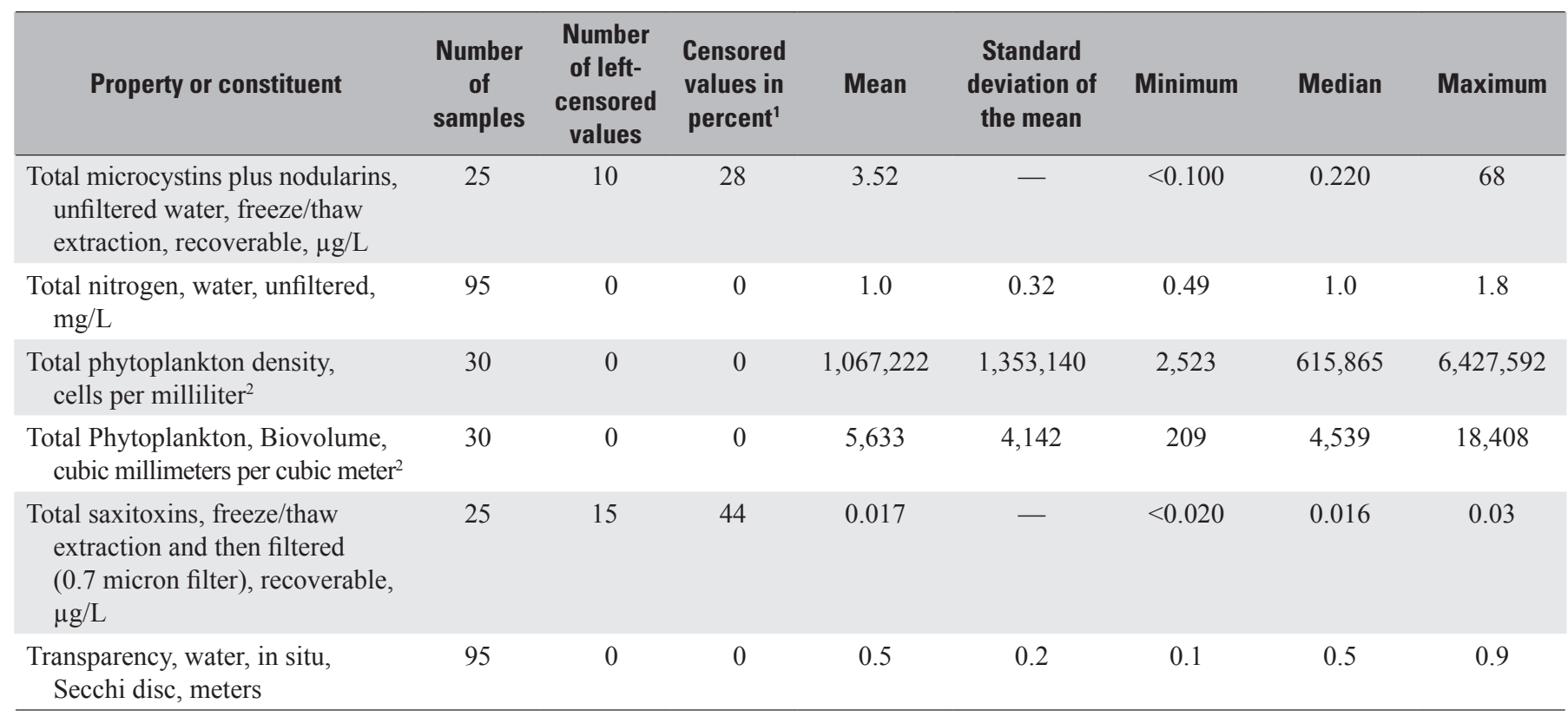

${ }^{1} \mathrm{Log}$ regression on statistics was used to compute summary statistics for analytes with left-censored data values. Means and standard deviations were not computed if more than 80 percent of data values within a dataset were censored (Bonn, 2008).

${ }^{2}$ North Carolina Department of Environment and Natural Resources Division of Water Resources (2014). These values are computed, reported without rounding, and likely reflect too much precision. Standard rounding procedures are in development.

Table 6. Comparison of results to water-quality thresholds for samples collected in the Albemarle Sound and tributaries, March 2013 through February 2014.

[Units: std, standard; $\mu \mathrm{g} / \mathrm{L}$, microgram per liter; $\mathrm{mg} / \mathrm{L}$; milligram per liter; $\mathrm{mL}$, milliliter. Reference: NCDENR, North Carolina Department of Environment and Natural Resources. <, less than; >, greater than; - , not applicable]

\begin{tabular}{|c|c|c|c|c|c|}
\hline \multirow[b]{2}{*}{ Constituent } & \multirow[b]{2}{*}{ Type } & \multicolumn{4}{|c|}{ Saltwater } \\
\hline & & $\begin{array}{l}\text { Most restrictive water- } \\
\text { quality threshold }\end{array}$ & Reference & $\begin{array}{c}\text { Number of } \\
\text { exceedances }\end{array}$ & Sites (see fig. 2) \\
\hline $\mathrm{pH}$ & Field & $<6.8$ or $>8.5$ std units & NCDENR (2007) & 15 & $\begin{array}{l}11,15,23,25,28 \\
30, \text { and } 32\end{array}$ \\
\hline Cyanobacteria (density) ${ }^{1}$ & Biological & 100,000 cells $/ \mathrm{mL}$ & Chorus and Bartram (1999) & 26 & $\begin{array}{l}11,15,16,19,23, \\
25,28-30, \text { and } 32\end{array}$ \\
\hline
\end{tabular}

${ }^{1}$ North Carolina Department of Environment and Natural Resources Division of Water Resources (2014).

${ }^{2}$ Sample was collected in response to a phytoplankton bloom observed on the Chowan River and analyzed for toxins and glyphosate only. 


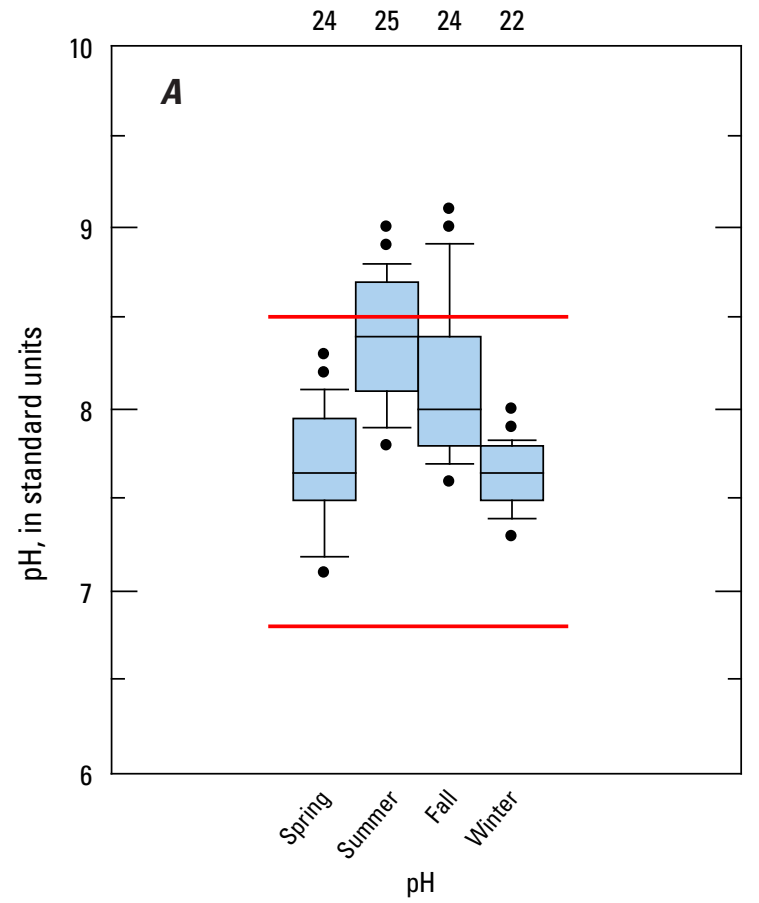

\section{EXPLANATION}

- Individual observation above

90th percentile

90th percentile

75th percentile

50th percentile (median)

25th percentile

10th percentile

- Individual observation below 10th percentile

Saltwater standard or guideline

Field parameter
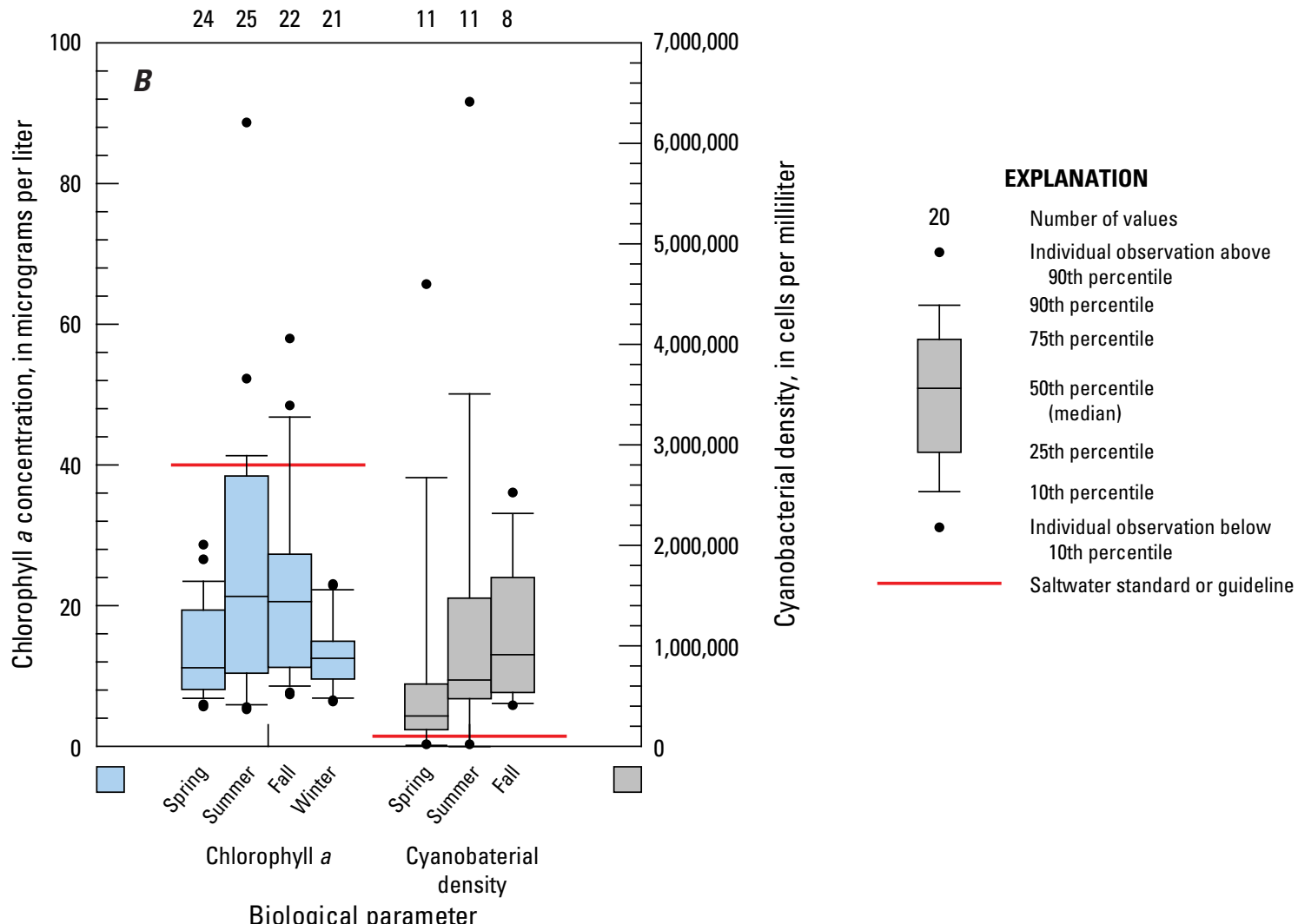

Figure 13. Properties of water samples collected in the Albemarle Sound study area from March 2013 through February 2014, grouped into two categories, with concentrations that were greater than a water-quality threshold. $A$, field and $B$, biological. 


\section{Field Measurements}

The RDDs ranged from 0 to 1.1 percent, varied across the Albemarle Sound study area, and varied seasonally for seven sites from March 2013 through February 2014 (appendix table 3-4 and fig. 14). All sites were vertically homogenous $(\mathrm{RDD}=0$ percent $)$ at least twice during the study period. The RDD was low $(<0.2$ percent) in all but two cases. The two highest RDDs were 1.1 and 0.31 percent, both observed in the Roanoke Sound (site 32; fig. 2) in August and September, respectively. For most sites, the RDD was highest from the middle of summer to the middle of fall. Overall, variable and weak density stratification observed from March 2013 through February 2014 suggests that the water column is generally well mixed across the Currituck and Roanoke Sounds and the Yeopim, North, and Little Rivers during all seasons.
Values of $\mathrm{pH}$ ranged from 7.1 to 9.1 standard units and only exceeded the $8.5 \mathrm{pH}$ threshold in 14 percent of the samples, all during the summer and fall. As previously noted, elevated $\mathrm{pH}$ is often indicative of phytoplankton blooms especially when coupled with high dissolved oxygen saturation values in the summer time (North Carolina Department of Environment and Natural Resources Division of Water Quality, 2003). In 2013 and 2014, water column transparencies measured by Secchi depth ranged from 0.1 to $0.9 \mathrm{~m}$ with a median value of $0.5 \mathrm{~m}$. Suspended sediment concentration ranged from less than 15 to $120 \mathrm{mg} / \mathrm{L}$ and was highest in the spring and fall. Median euphotic depth was $1.35 \mathrm{~m}$ and ranged from 0.27 to $2.43 \mathrm{~m}$ in $2013-14$.

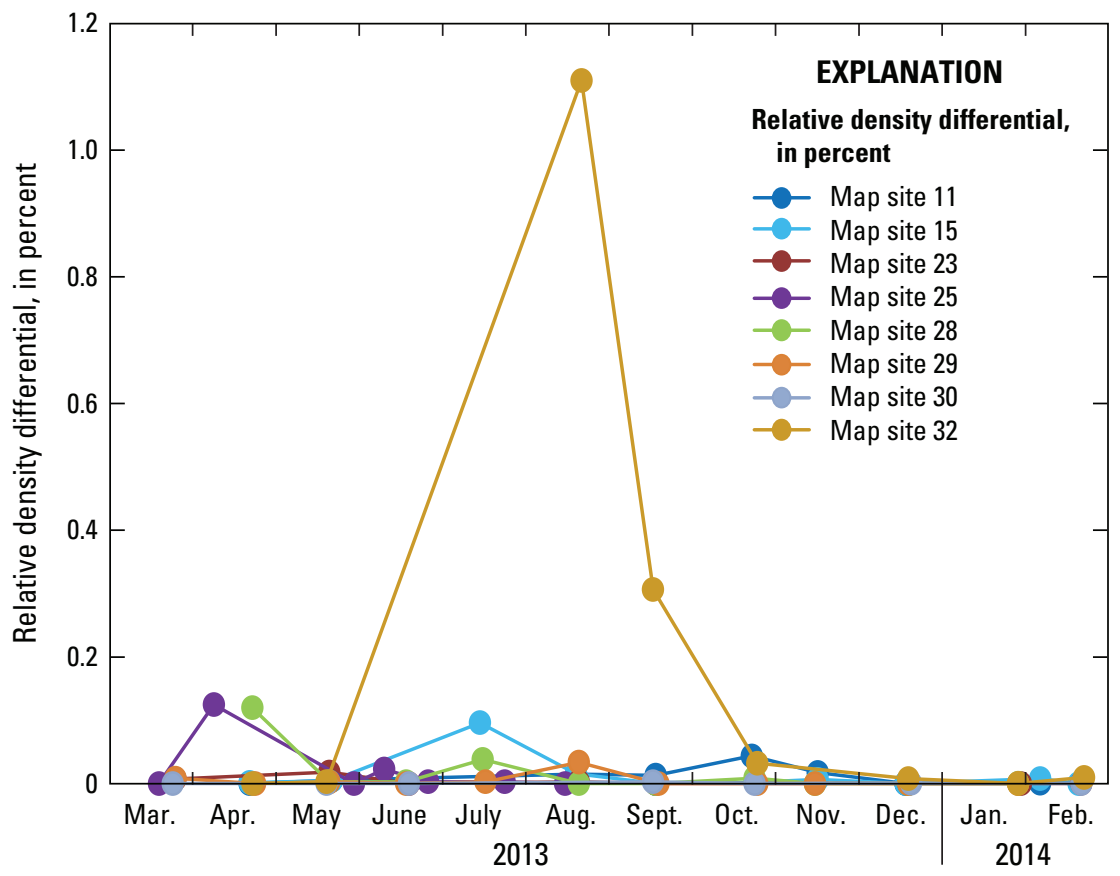

Figure 14. Calculated relative density differential for sites (table 1; fig. 2) sampled in the Albemarle Sound study area from March 2013 through February 2014. 


\section{Chemical Data}

The TN values ranged from 0.49 to $1.8 \mathrm{mg} / \mathrm{L}$ with a median value of $1.0 \mathrm{mg} / \mathrm{L}$. The $\mathrm{TN}$ values were highest in the fall and lowest in the winter (fig. 15). Similar to conditions in 2012, most nitrogen was organic nitrogen (total Kjeldahl nitrogen minus ammonia nitrogen) during all sample periods. Phosphorus values ranged from 0.02 to $0.192 \mathrm{mg} / \mathrm{L}$ with a median value of $0.049 \mathrm{mg} / \mathrm{L}$. Phosphorus values tended to be lowest in summer (fig. 15). Similar to conditions in 2012, the dissolved fractions of phosphorus and TN were a small portion of the total concentrations, suggesting that both nutrients could be limiting phytoplankton growth.

\section{Biological Data}

Chlorophyll $a$ values ranged from 5 to $88.4 \mu \mathrm{g} / \mathrm{L}$ in the monthly samples collected in 2013-14. The State threshold of $40 \mu \mathrm{g} / \mathrm{L}$ was exceeded in 9 percent of the samples and only during the summer and fall growing seasons. As previously noted, chlorophyll $a$ values may be biased low, and thus the concentrations and numbers of values greater than any threshold may be underestimated.

Phytoplankton community composition was determined in samples collected during April, July, and October in the Currituck Sound, Yeopim, Little, and North Rivers. In addition, samples were collected as part of the DWR ambient monitoring program in the Chowan, Alligator, Pasquotank, and Roanoke Rivers in April and July and during an apparent bloom event that occurred in the Chowan River in August 2013 (fig. 16). Phytoplankton density ranged from about 2,500 to about 6.4 million cells $/ \mathrm{mL}$ with a median value of about 616,000 cells $/ \mathrm{mL}$. Note the variability of phytoplankton metrics may have affected these values in addition to those for cyanobacteria.

In 2013, cyanobacteria again dominated total phytoplankton cell densities in all samples collected (fig. 17). Cyanobacteria densities ranged from about 600 to about

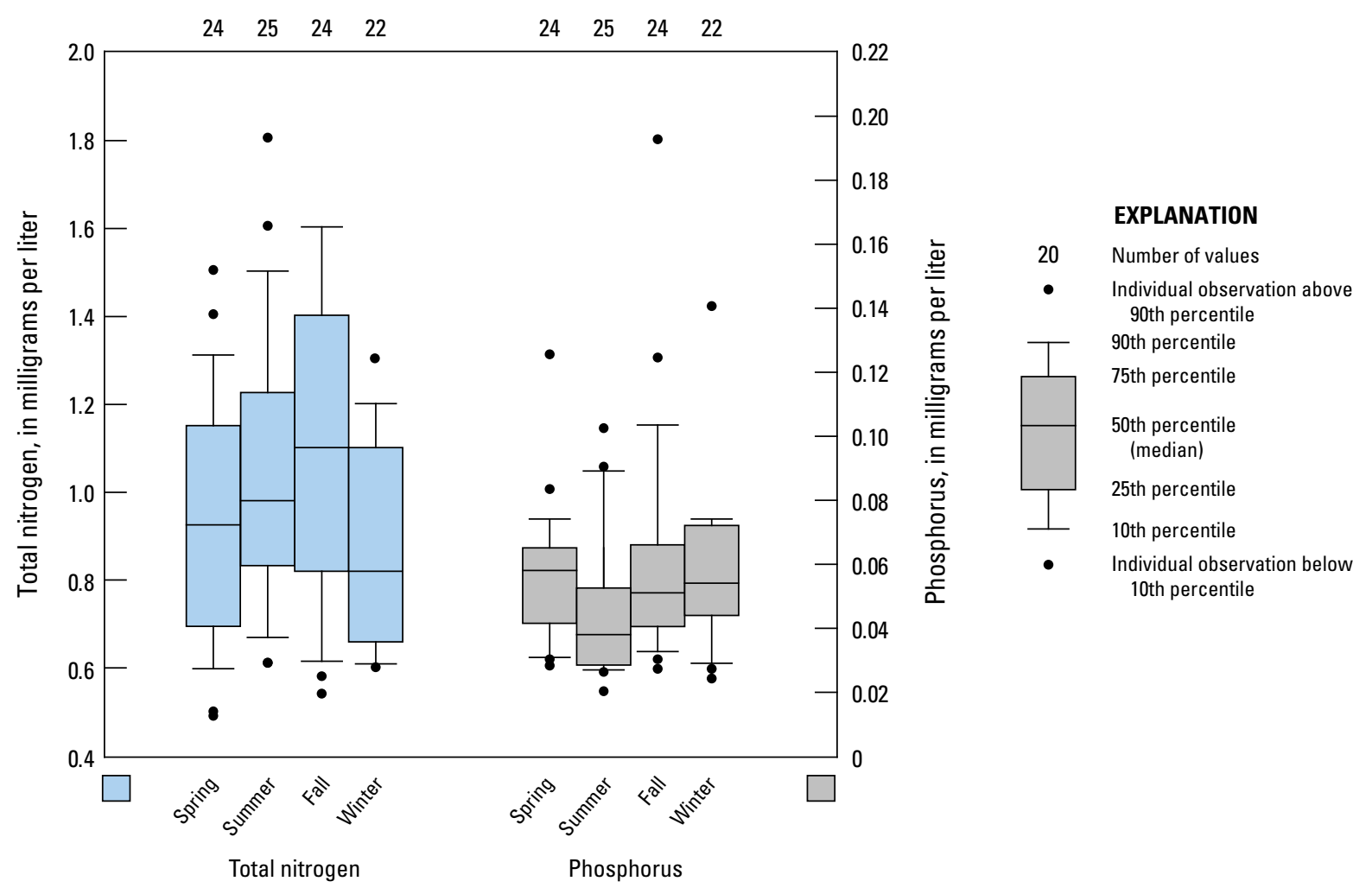

Chemical parameter

Figure 15. Seasonal concentration summaries of total nitrogen and phosphorus in the Albemarle Sound study area, 2013-14. 
6.4 million cells $/ \mathrm{mL}$, with a median value of about 579,000 cells $/ \mathrm{mL}$. Eighty-seven percent of the samples (26 of 30) collected exceeded the WHO provisional guidance for moderate health alert in recreational waters (cyanobacteria cell counts greater than 100,000 cells $/ \mathrm{mL}$ ) (Chorus and Bartram, 1999). The caveat again is this is a freshwater guideline and so its use here for these saltwater sites is meant only as a general indication of potential risk. Anabaena, Aphanizomenon, Aphanocapsa, Cylindrospermosis, and Pseudoanabaena are all potential toxin-producing cyanobacteria genera (Graham and others, 2008). Some or all of these species were present in all but one sample. Potential toxin-producing cyanobacteria as a percentage of the cyanobacteria community ranged from 2 to 100 percent (median $=32$ percent). Cyanotoxins were detected at low levels and did not exceed recommended thresholds except in the sample collected on August 13, 2013, at the Chowan River at Mount Gold, N.C. (site E2). This sample reflected an apparent bloom of Anabaena with a microcystin concentration of $68 \mu \mathrm{g} / \mathrm{L}$. A second sample collected on the Chowan River at channel marker 10 near Arrowhead Beach, N.C. (site E1) on August 29, 2013, indicated phytoplankton biomass had dissipated, and toxins were no longer present at levels unsafe for recreational use. As was the case for the 2012 samples, microcystin was most frequently detected cyanotoxin (60 percent of analyses) and had the highest median $(0.17 \mu \mathrm{g} / \mathrm{L})$ and maximum $(68 \mu \mathrm{g} / \mathrm{L})$ concentrations determined (table 5.).

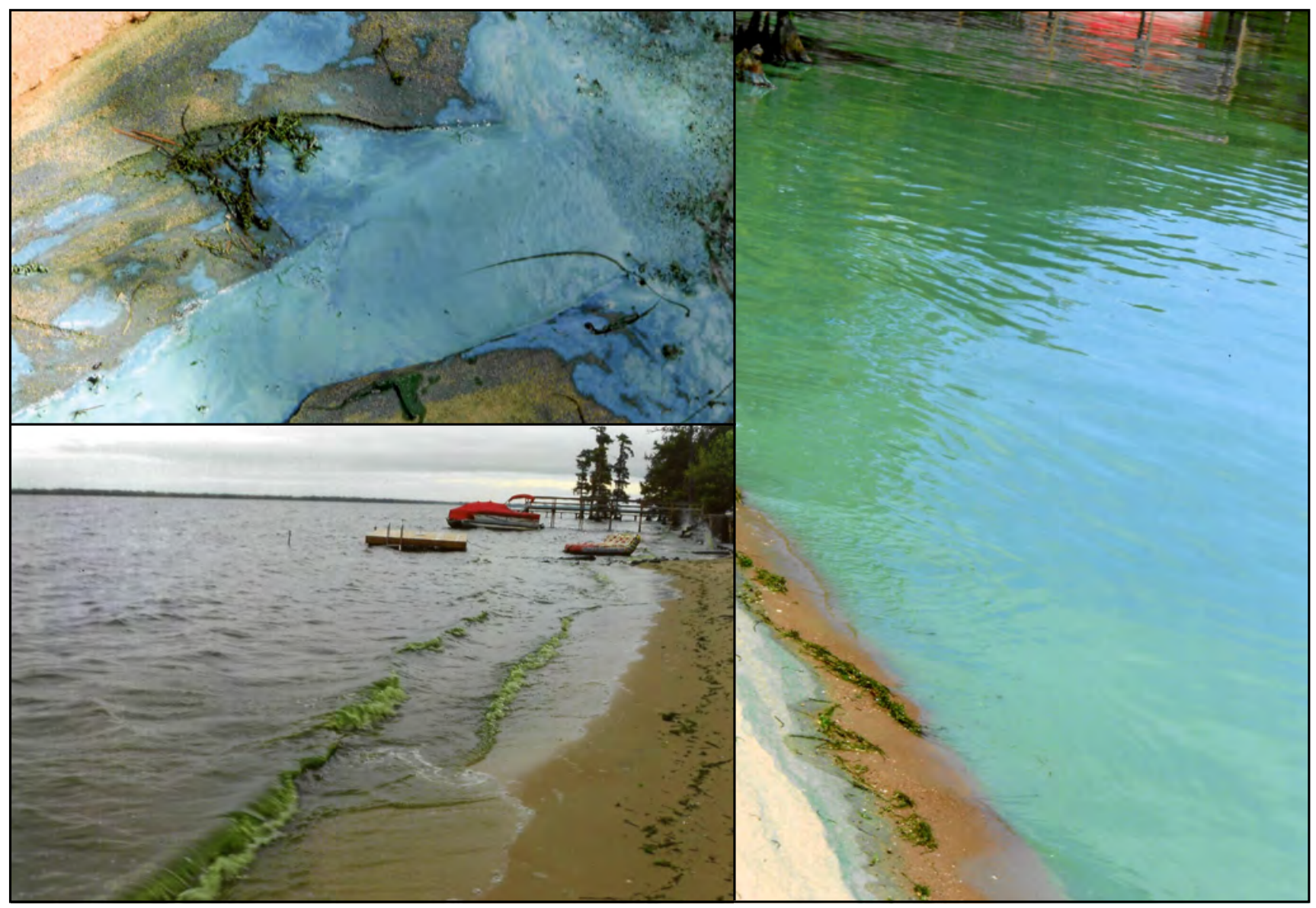

Figure 16. Elevated levels of the cyanotoxin, microcystin, were measured at 68 parts per billion in a bloom dominated by Anabaena in the Chowan River on August 13, 2013 (Photographs by Rhonda W. McClenney). 


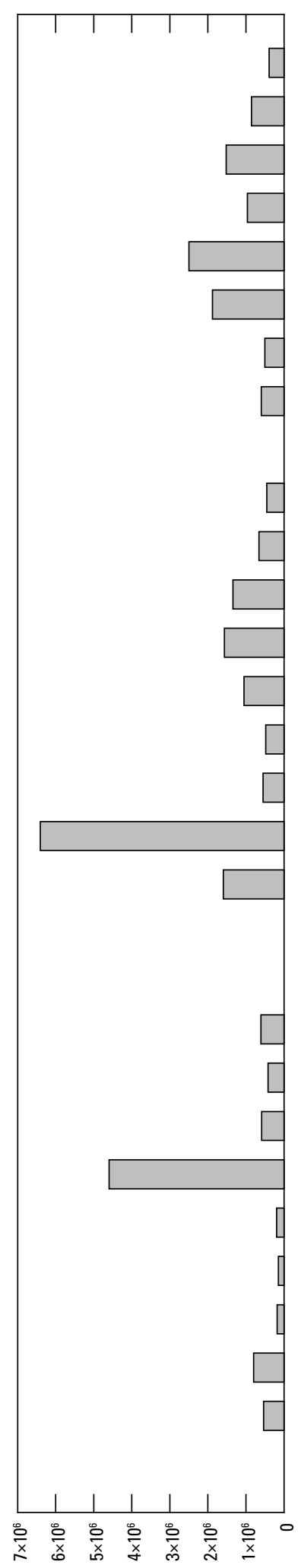

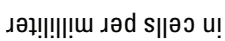

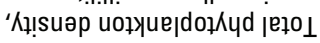
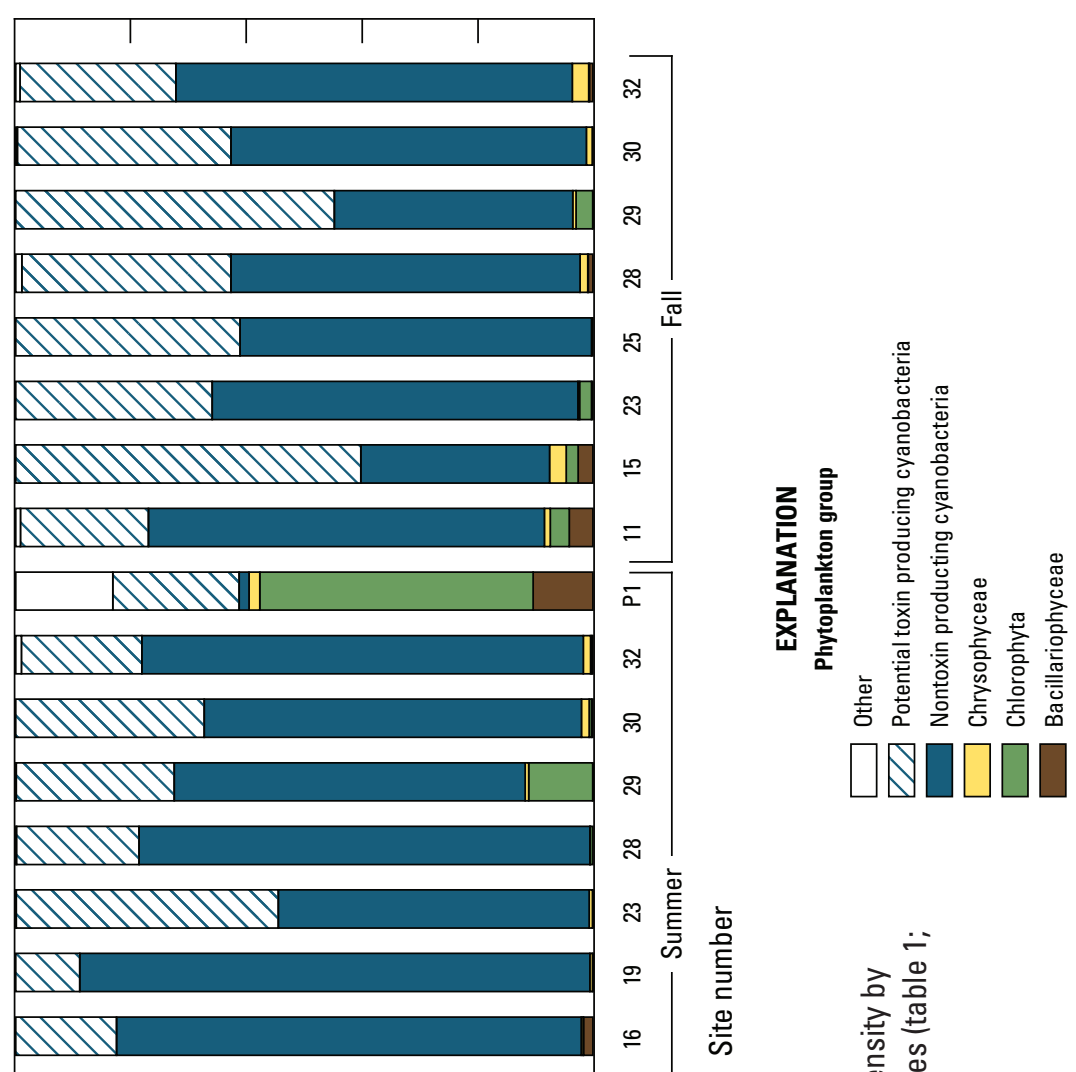

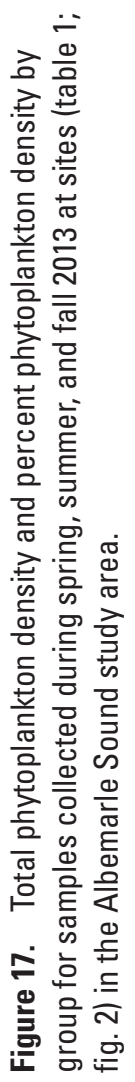

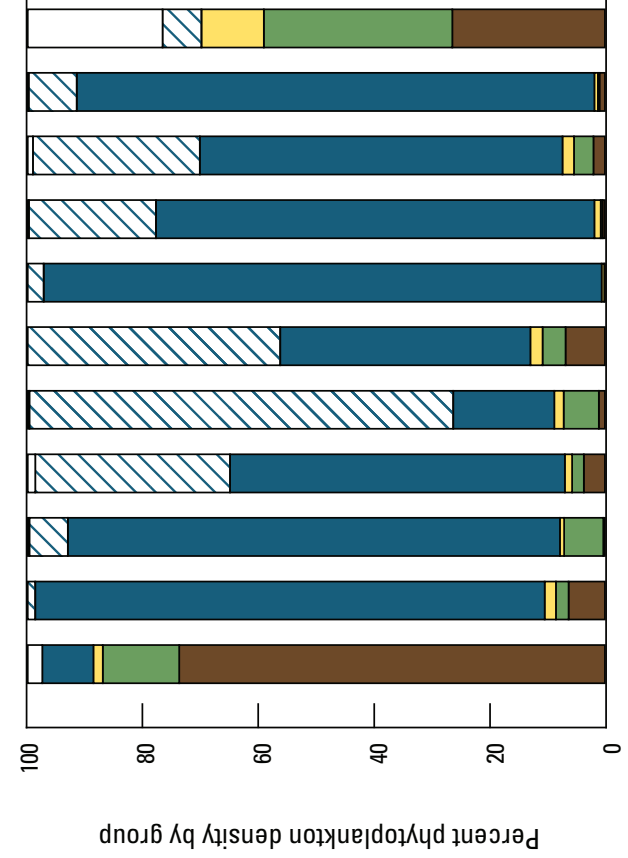

बे
है
ट
के
के

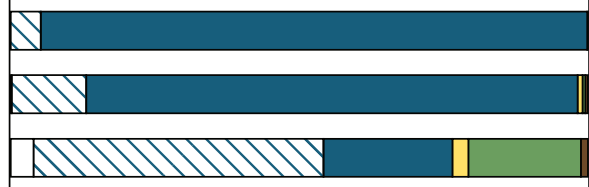




\section{Occurrence and Distribution of Elements in Bed Sediment}

Bed sediment sampling sites were chosen to investigate the occurrence and distribution of various metals including those linked to toxicity to aquatic organisms. Major tributary estuaries were sampled in addition to sites in the Albemarle Sound (fig. 2). Concentrations of metals, total organic carbon, and particle size distributions are shown in appendix 4 (all constituents in bed sediment samples collected in Albemarle Sound and tributaries, 2012) and summary statistics are shown in table 7. Iron and aluminum had the highest mean concentrations followed by magnesium, calcium, sodium, and potassium. These metals are commonly associated with various mineral matrices that are not considered particularly bioavailable. Thus, total recoverable concentrations reported here probably include some fraction that is not necessarily bioavailable and therefore possibly less toxic. In addition, high concentrations of iron as well as manganese can reflect the nearly ubiquitous oxyhydroxide coatings on sediment particles (Jenne, 1968). All other metals are present in lower concentrations in comparison to these seven metals.

Bed sediment-quality thresholds are shown separately for freshwater and saltwater sites (table 8.). The marine thresholds were used to assess saltwater sites. When more than one threshold exists, the most restrictive one was used for comparison to study data. Because the elemental thresholds are for total concentrations, using total recoverable concentrations that do not necessarily include a complete dissolution of the mineral matrix might underestimate the number of elevated values. Twelve metals exceeded either the freshwater or marine threshold, or both. Five metals did not exceed a threshold, and nine elements had no threshold for comparison. The 7 freshwater sites had 25 elevated values among 7 metals (aluminum, chromium, copper, iron, lead, manganese, and mercury). In comparison, 13 saltwater sites had only 16 elevated values but for 10 metals (aluminum, arsenic, cadmium, cobalt, copper, lead, manganese, mercury, nickel, and zinc). Manganese and iron together accounted for more than one-half of the elevated values at freshwater sites, whereas aluminum and manganese accounted for almost one-half of the elevated values at the saltwater sites. Three of these freshwater sites, Chowan River near Edenhouse, N.C. (site 3), Cashie River at Sans Souci Ferry, N.C. (site 6), and Albemarle Sound near Edenton Airport near Edenton, N.C. (site 9), accounted for 17 of the 25 elevated values at the freshwater sites. Perquimans River at U.S. Hwy 17 at Hertford, N.C. (site 10) had the most elevated values (6) of any saltwater site. These four sites are in the western or northwestern part of the Albemarle Sound study area (fig. 2). Note that analytical bias could not be determined for several of these metals (aluminum, chromium, iron, lead, manganese, and zinc). Bed sediment concentrations of chromium, lead, mercury, nickel, and zinc also exceeded some criteria in a previous study that included Albemarle Sound conducted between 1994 and 1997 (Hackney and others, 1998).
Of the 12 metals with at least 1 concentration above a threshold (fig. 18), 5 metals (arsenic, copper, lead, nickel, and zinc) had relatively few high values that appeared to be largely outliers and therefore apparently atypical for the study area. The other seven metals (aluminum, cadmium, chromium, cobalt, iron, manganese, and mercury) had more numerous values above the respective thresholds. Within this latter group, aluminum, iron, and manganese tend to occur in mineral matrices or as coatings on minerals. In contrast, cadmium, chromium, cobalt, and mercury potentially reflected anthropogenic inputs sorbed to particle coatings.

The concentration of metals in bed sediments is a function not just of the input history but also of the ability of the sediment to retain metals, largely through sorption on the mineral surface. Generally, average particle size is inversely related to surface area in sediments. That is, smaller particles have more surface area per unit mass than larger particles. Thus, for metals largely associated with coatings on minerals, elevated values frequently occurred in samples classified as clay or silty clay because of the relatively large surface area available for sorption (appendix 4). Conversely, sites with coarser particles classified as sand or loamy sand had no elevated values. An exception was Perquimans River at U.S. Hwy 17 at Hertford, N.C. (site 10), which had the most elevated values (6) of any saltwater site, yet had a sandy loam texture. The total organic carbon concentration at this site was 11.4 weight percent (mass of organic carbon divided by sediment dry mass times 100) (appendix 4). This concentration was the second highest concentration measured among the saltwater sites and the third highest concentration measured at any site (range $=0.12$ to 13.4 weight percent). The bed sediment at this site contained macroscopic organic detritus (vegetation) in addition to mussel shells with associated tissue; thus, neither the organic carbon nor the metals were necessarily associated with the silt plus clay fraction, making this site less comparable to the other sites in that regard. Also, the original site selected was the bridge area, which yielded mostly sand that was not collected. The sampling site was moved several hundred meters upstream near a boat dock. The relatively small-scale heterogeneity observed at this and other sites suggests caution when interpreting the representativeness of these samples of larger areas surrounding the sampling sites.

Because metals are commonly associated with fine, organic-rich particles, the spatial distribution of these sediment characteristics was mapped. Fine particles (silt plus clay fraction) ranged from 4.4 to 98.9 weight percent, and sediment textures ranged from sand to clay (appendix 4). Fines generally dominated the particle size distribution upstream and at the mouths of the tributary estuaries but were scarcer in the outer sound and near the outer banks (fig. 19A). Total organic carbon ranged from 0.12 to 13.4 weight percent and followed the same general spatial distribution as the fine particles (fig. 19B). Indeed, the overall positive correlation between fines and total organic carbon for most sites was consistent with the fine particles being coated with an organic carbon layer (fig. 20). Three outliers (sites 14, 2, and 10) had much 
Table 7. Summary statistics for bed-sediment quality data collected in the Albemarle Sound and tributaries, 2012.

[g/kg, gram per kilogram; mg/kg, milligram per kilogram. <, less than; —, not calculated]

\begin{tabular}{|c|c|c|c|c|c|c|c|c|c|}
\hline Element & Unit & $\begin{array}{c}\text { Number } \\
\text { of } \\
\text { samples }\end{array}$ & $\begin{array}{c}\text { Number } \\
\text { of left- } \\
\text { censored } \\
\text { values }\end{array}$ & $\begin{array}{c}\text { Censored } \\
\text { values in } \\
\text { percent }\end{array}$ & Mean' & $\begin{array}{l}\text { Standard } \\
\text { deviation of } \\
\text { the mean' }\end{array}$ & Minimum & Median & Maximum \\
\hline $\begin{array}{l}\text { Antimony, bed sediment, } \\
\text { recoverable, dry weight }\end{array}$ & $\mathrm{mg} / \mathrm{kg}$ & 20 & 0 & 0 & 0.050 & 0.036 & 0.0092 & 0.0435 & 0.16 \\
\hline $\begin{array}{l}\text { Barium, bed sediment, } \\
\text { recoverable, dry weight }\end{array}$ & $\mathrm{mg} / \mathrm{kg}$ & 20 & 0 & 0 & 75.6 & 66.6 & 2.4 & 70.9 & 215 \\
\hline $\begin{array}{l}\text { Beryllium, bed sediment, } \\
\text { recoverable, dry weight }\end{array}$ & $\mathrm{mg} / \mathrm{kg}$ & 20 & 0 & 0 & 0.715 & 0.517 & 0.039 & 0.61 & 1.6 \\
\hline $\begin{array}{l}\text { Boron, bed sediment, } \\
\text { recoverable, dry weight }\end{array}$ & $\mathrm{mg} / \mathrm{kg}$ & 20 & 3 & 15 & 5.2 & 3.7 & $<3.4$ & 4.2 & 13.1 \\
\hline $\begin{array}{l}\text { Chromium, bed sediment, } \\
\text { recoverable, dry weight }\end{array}$ & $\mathrm{mg} / \mathrm{kg}$ & 20 & 0 & 0 & 18.8 & 12.0 & 2 & 17.5 & 38 \\
\hline $\begin{array}{l}\text { Cobalt, bed sediment, } \\
\text { recoverable, dry weight }\end{array}$ & $\mathrm{mg} / \mathrm{kg}$ & 20 & 0 & 0 & 7.8 & 5.6 & 0.3 & 7.6 & 21 \\
\hline $\begin{array}{l}\text { Copper, bed sediment, } \\
\text { recoverable, dry weight }\end{array}$ & $\mathrm{mg} / \mathrm{kg}$ & 20 & 0 & 0 & 9.80 & 7.18 & 0.58 & 9.55 & 30.3 \\
\hline $\begin{array}{l}\text { Iron, bed sediment, } \\
\text { recoverable, dry weight }\end{array}$ & $\mathrm{mg} / \mathrm{kg}$ & 20 & 0 & 0 & 19,977 & 13,921 & 730 & 17,000 & 50,000 \\
\hline $\begin{array}{l}\text { Lead, bed sediment, } \\
\text { recoverable, dry weight }\end{array}$ & $\mathrm{mg} / \mathrm{kg}$ & 20 & 0 & 0 & 18.8 & 17.1 & 1.8 & 17 & 77 \\
\hline $\begin{array}{l}\text { Nickel, bed sediment, } \\
\text { recoverable, dry weight }\end{array}$ & $\mathrm{mg} / \mathrm{kg}$ & 20 & 0 & 0 & 8.3 & 4.7 & 0.8 & 8.3 & 16 \\
\hline $\begin{array}{l}\text { Organic carbon, bed sediment, } \\
\text { total, dry weight }\end{array}$ & $\mathrm{g} / \mathrm{kg}$ & 20 & 0 & 0 & 43.2 & 38.3 & 1.2 & 37 & 130 \\
\hline $\begin{array}{l}\text { Potassium, bed sediment, } \\
\text { recoverable, dry weight }\end{array}$ & $\mathrm{mg} / \mathrm{kg}$ & 20 & 0 & 0 & 1,097 & 643 & 90 & 1,035 & 2,200 \\
\hline $\begin{array}{l}\text { Selenium, bed sediment, } \\
\text { recoverable, dry weight }\end{array}$ & $\mathrm{mg} / \mathrm{kg}$ & 20 & 2 & 10 & 0.29 & 0.21 & $<0.17$ & 0.25 & 0.9 \\
\hline $\begin{array}{l}\text { Silver, bed sediment, } \\
\text { recoverable, dry weight }\end{array}$ & $\mathrm{mg} / \mathrm{kg}$ & 20 & 0 & 0 & 0.073 & 0.055 & 0.0044 & 0.081 & 0.18 \\
\hline $\begin{array}{l}\text { Sodium, bed sediment, } \\
\text { recoverable, dry weight }\end{array}$ & $\mathrm{mg} / \mathrm{kg}$ & 20 & 0 & 0 & 2,017 & 2,116 & 60 & 1,400 & 7,400 \\
\hline $\begin{array}{l}\text { Thallium, bed sediment, } \\
\text { recoverable, dry weight }\end{array}$ & $\mathrm{mg} / \mathrm{kg}$ & 20 & 1 & 5 & 0.20 & 0.14 & $<0.17$ & 0.2 & 0.45 \\
\hline $\begin{array}{l}\text { Vanadium, bed sediment, } \\
\text { recoverable, dry weight }\end{array}$ & $\mathrm{mg} / \mathrm{kg}$ & 20 & 0 & 0 & 25.7 & 17.9 & 2.3 & 21.75 & 59.5 \\
\hline $\begin{array}{l}\text { Zinc, bed sediment, } \\
\text { recoverable, dry weight }\end{array}$ & $\mathrm{mg} / \mathrm{kg}$ & 20 & 0 & 0 & 49.4 & 37.7 & 2 & 49.5 & 160 \\
\hline
\end{tabular}

${ }^{1}$ Log regression on statistics was used to compute summary statistics for analytes with left-censored data values. 
Table 8. Comparison of results to bed-sediment quality thresholds for samples collected in the Albemarle Sound and tributaries, 2012.

[mg/kg, milligram per kilogram; —, not applicable]

\begin{tabular}{|c|c|c|c|c|c|c|}
\hline \multirow[b]{2}{*}{ Element } & \multicolumn{3}{|c|}{ Freshwater } & \multicolumn{3}{|c|}{ Saltwater } \\
\hline & $\begin{array}{c}{ }^{1} \text { Most restrictive } \\
\text { threshold } \\
(\mathrm{mg} / \mathrm{kg})\end{array}$ & $\begin{array}{c}\text { Number of } \\
\text { exceedances }\end{array}$ & $\begin{array}{l}\text { Sites } \\
\text { (fig. 2) }\end{array}$ & $\begin{array}{c}{ }^{1} \text { Most restrictive } \\
\text { threshold } \\
(\mathrm{mg} / \mathrm{kg})\end{array}$ & $\begin{array}{c}\text { Number of } \\
\text { exceedances }\end{array}$ & $\begin{array}{l}\text { Sites } \\
\text { (fig. 2) }\end{array}$ \\
\hline Aluminum & 25,500 & 3 & 3,6 , and 9 & 18,000 & 4 & $11,13,14$, and 15 \\
\hline Antimony & 3 & 0 & - & 0.63 & 0 & - \\
\hline Arsenic & 5.9 & 0 & - & 7.24 & 1 & 11 \\
\hline Barium & - & - & - & 130.1 & 0 & - \\
\hline Cadmium & 0.583 & 0 & - & 0.38 & 2 & 10,14 \\
\hline Chromium & 26 & 3 & 3,6 , and 9 & 49 & 0 & - \\
\hline Cobalt & 50 & 0 & - & 10 & 1 & 10 \\
\hline Copper & 16 & 2 & 6 and 9 & 18.7 & 1 & 10 \\
\hline Iron & 20,000 & 6 & $1,2,3,5,6$, and 9 & 220,000 & 0 & - \\
\hline Lead & 31 & 1 & 3 & 30 & 1 & 10 \\
\hline Manganese & 460 & 7 & $\begin{array}{c}1,2,3,5,6 \\
7, \text { and } 9\end{array}$ & 260 & 3 & 11,13, and 15 \\
\hline Mercury & 0.174 & 3 & 6,7, and 9 & 0.13 & 1 & 10 \\
\hline Nickel & 16 & 0 & - & 15 & 1 & 15 \\
\hline Zinc & 98 & 0 & - & 94 & 1 & 10 \\
\hline Selenium & - & - & - & 1 & 0 & - \\
\hline Silver & 0.5 & 0 & - & 0.23 & 0 & - \\
\hline Vanadium & - & - & - & 57 & 0 & - \\
\hline
\end{tabular}

${ }^{1}$ All thresholds are from Buchman (2008).

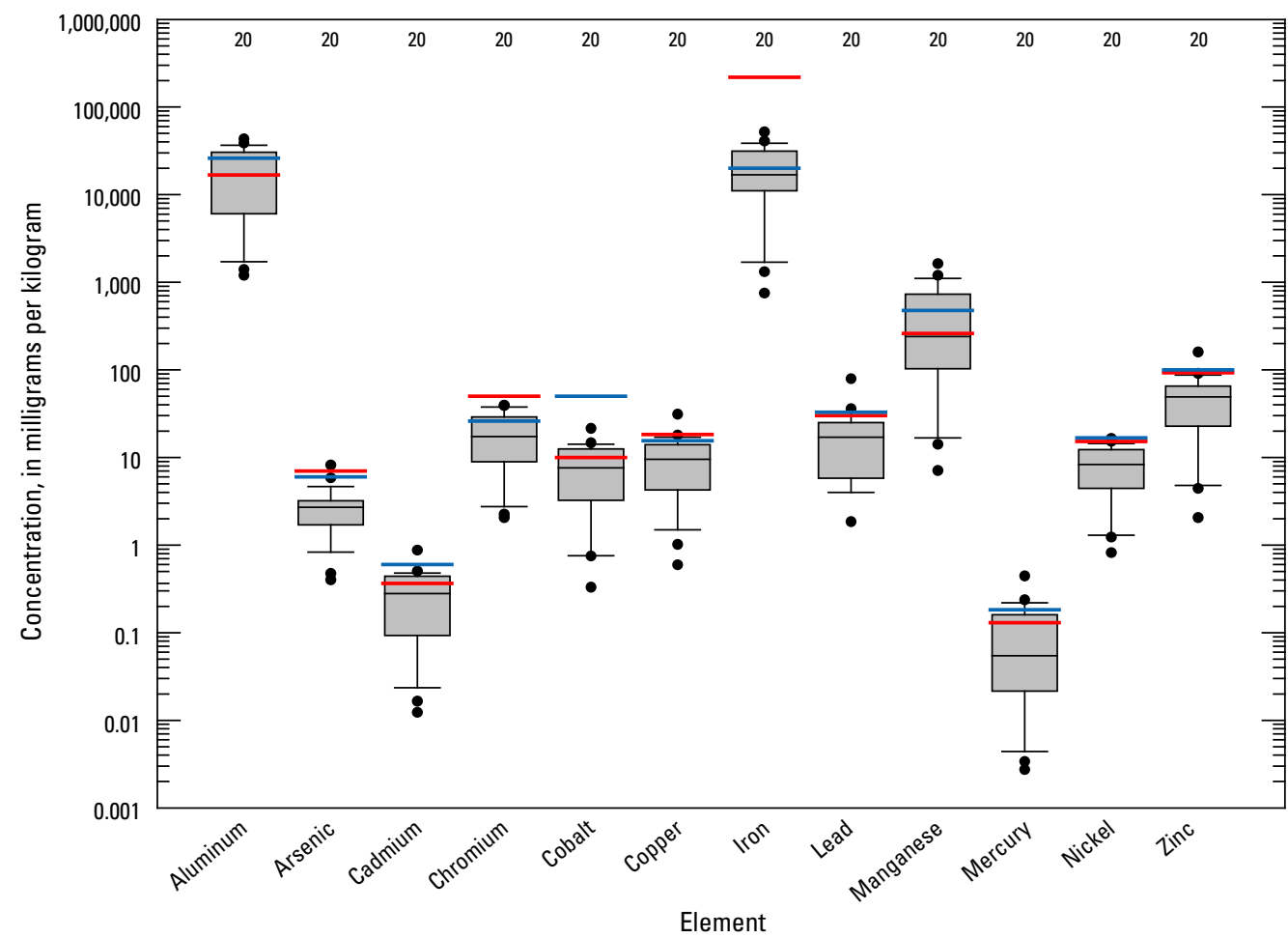

\section{EXPLANATION}

20

- Individual observation above 90th percentile

90th percentile

75th percentile

50th percentile (median)

25th percentile

10th percentile

Individual observation below 10th percentile

Most restrictive saltwater standard or guideline

Most restrictive freshwater standard or guideline

Figure 18. Element concentrations in bed sediments from the Albemarle Sound and tributaries in 2012 that were greater than at least one bed sediment threshold. Log of the regression on statistics (Bonn, 2008) was used to calculate percentiles for mercury. 

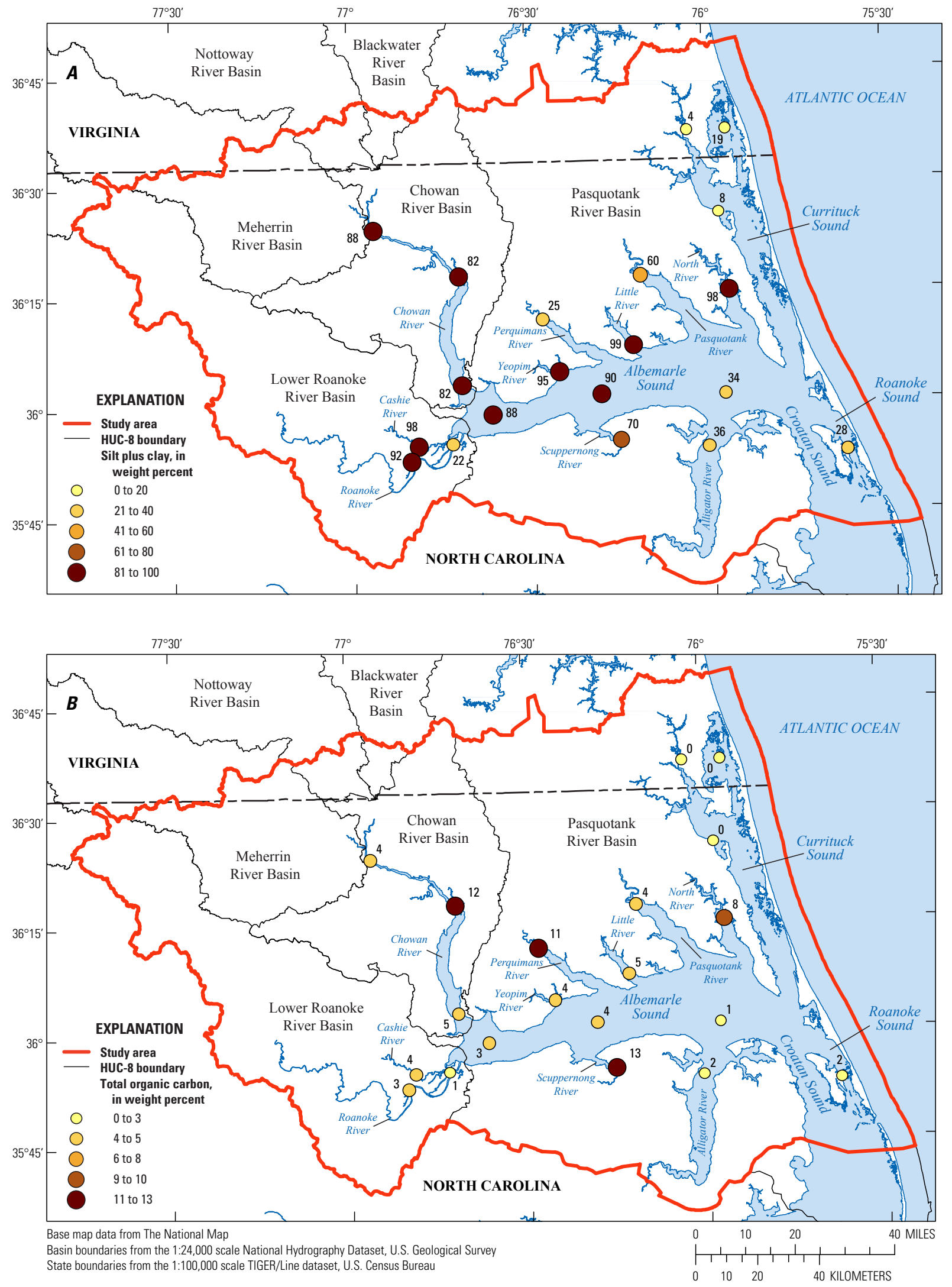

Figure 19. Properties of bed sediments from the Albemarle Sound and tributaries in 2012. A, fine particles (silt plus clay), in weight percent and $B$, total organic carbon, in weight percent. 


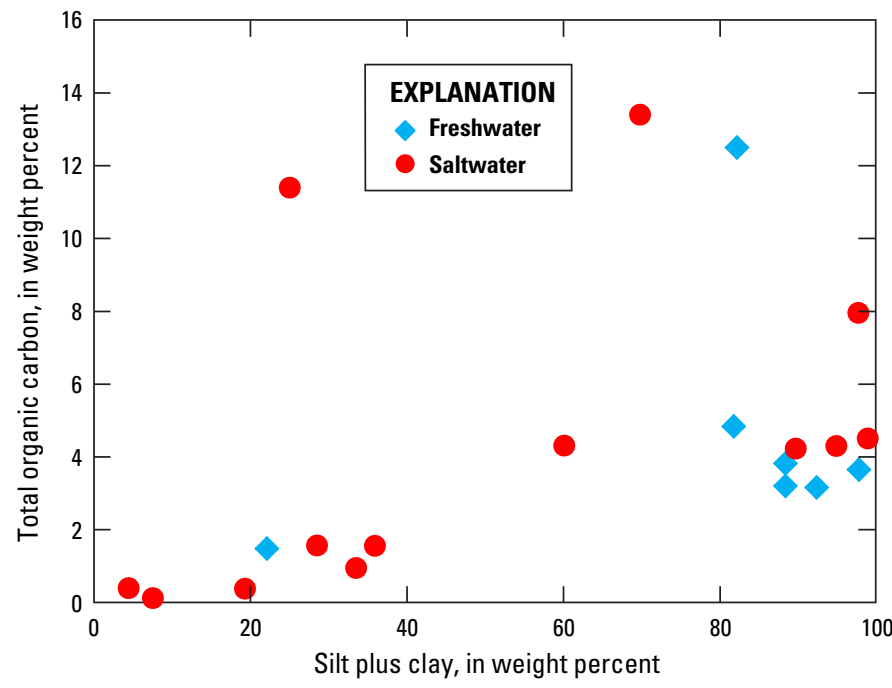

Figure 20. Relation between silt plus clay and total organic carbon in surficial bed sediments from the Albemarle Sound and tributaries, 2012.

higher fine-normalized total organic carbon values than the rest of the sites. Two of these three sites (sites 14 and 2) had dark-brown mud underlying a light-brown flocculent layer. If the flocculent layer was the remnants of a senescing phytoplankton bloom or other biological material, that would be consistent with a higher fine-normalized total organic carbon value. The third site, Perquimans River (site 10), had macroscopic organic detritus (vegetation) and mussels present as previously mentioned.

Albemarle Sound near Edenton Airport near Edenton, N.C. (site 9) had the highest number of maximum bed sediment concentrations for the following five trace metals: chromium, copper, mercury, nickel, and zinc (appendix 4). Site 9 is near the confluence of the Roanoke and Chowan Rivers as they enter the western end of Albemarle Sound (fig. 2). Because this site does not have a particularly high total organic carbon concentration or silt plus clay fraction among the freshwater sites (figs. 19A-19B), proximity to one or more sources contributing metal-laden particles might drive the large number of maximum values there. Perquimans River at U.S. Hwy 17 at Hertford, N.C. (site 10) had the maximum concentrations for 6 of the 10 trace metals, the most of any saltwater site. These metals included cadmium, cobalt, copper, lead, mercury, and zinc. Although the total organic carbon concentration at this site was relatively high (11.4 weight percent), the silt plus clay fraction was extremely low (25 weight percent) (appendix 4). Association of these metals with discrete organic detritus such as dead and decomposing phytoplankton cells, as opposed to organic coatings on fine particles, would be consistent with these findings. Potential sources of metals above this station include a mill that makes steel plates.

Fine sediment in most of Albemarle Sound has a relatively short residence time based on radioisotopic inventories (Corbett and others, 2007). This material appears to be frequently resuspended by waves, currents, and tides and is flushed from the system. In the longer term of a few hundred years, Albemarle Sound has transitioned from more to less marine and is now a hyposaline system that is dominated by terrestrial inputs. This balance between increasing terrestrial inputs and the relatively rapid flushing of fines and associated metals from the system is a controlling factor on whether individual thresholds will be exceeded. Finally, the high variability of the system probably contributes to small scale spatial heterogeneity that was evident at some sites.

\section{Summary}

This report presents and summarizes water-quality and bed sediment quality data collected by the U.S. Geological Survey as part of the National Monitoring Network demonstration project in the Albemarle Sound region. Baseline data were collected at 34 sites to assess the occurrence and distribution of nutrients, major ions, metals, pesticides, and phytoplankton communities during the summer of 2012. During March 2013 through February 2014, additional data were collected at eight sites to improve understanding of water-quality conditions in previously unmonitored embayments of the Albemarle Sound. Based on comparison to available water-quality thresholds, the sites sampled appeared to be reasonably healthy. Only 13 of more than 40 constituents sampled in 2012 and only 5 of more than 20 constituents sampled in 2013-14 were elevated compared to thresholds. Elevated levels of chlorophyll $a$ and $\mathrm{pH}$ were found in the Albemarle Sound region and its embayments, especially in the northern parts of the middle and eastern Albemarle Sound. Large, multiple phytoplankton standing crops dominated by cyanobacteria were also detected in these regions during the 2012 and 2013 growing seasons. The World Health Organization cyanobacteria standard for moderate recreational risk was exceeded in approximately 76 percent of water samples collected in the summer of 2012 and 87 percent of water samples collected during 2013. Toxin-producing cyanobacteria were present, but cyanotoxins were mostly below human health benchmarks. More study would be required to investigate possible linkages between the incidence of cyanobacterial blooms and nutrient inputs to Albemarle Sound.

Several metals in bed sediments, including those linked to toxicity in aquatic organisms, were investigated for spatial distribution and association with organic carbon and fine particles. Although these were total recoverable concentrations and not total concentrations, the most abundant elements were those typically prevalent in mineral matrices and those associated with coatings on minerals including iron, aluminum, manganese, calcium, sodium, and potassium. Other metals were present in lower concentrations though some values were greater than aquatic health thresholds. These included chromium, copper, lead, and mercury at freshwater sites and arsenic, cadmium, cobalt, copper, lead, mercury, nickel, and 
zinc at saltwater sites. A total of 12 metals were detected at levels above a published sediment-quality threshold. These exceedances tended to occur in the western and northwestern parts of the study area. With few exceptions, most exceedances occurred at sites with high total organic carbon concentration or high percent of fines, or both. That said, there was some indication that some metals were associated not with organic coatings on the sediment but with organic detritus in the sediment. Finally, there was evidence of small-scale spatial heterogeneity in addition to large-scale temporal heterogeneity because of large storms resuspending surficial bed sediments. This emphasizes the need to periodically resample the bed sediments in a representative manner over time to understand the input and fate of contaminants that affect aquatic life in Albemarle Sound.

\section{References Cited}

Aga, D.S., Thurman, E.M., 1995, Application of solid-phase extraction (SPE) for ultratrace analysis of herbicides in water and soil by enzyme-linked immunosorbent assay (ELISA): Agrochemical Immunoanalysis-93, chap. 9, p. 123-136.

American Chemical Society, 2016, CAS REGISTRY-The gold standard for chemical substance information: American Chemical Society, Chemical Abstracts Service Web page, accessed August 2016 at https://www.cas.org/content/ chemical-substances.

American Public Health Association, 1998, Standard methods for the examination of water and wastewater (20th ed.): Washington, D.C., American Public Health Association, American Water Works Association, and Water Environment Federation, p. 3-37-3-43.

American Society for Testing and Materials, 1985, Standard test method for particle-size analysis of soils D 422-63 (1972): Philadelphia, Pa., American Society for Testing Materials, p. 117-127.

American Society for Testing and Materials, 2010, Standard test methods for dissolved oxygen in water D888-09C: Philadelphia, Pa., American Society for Testing Materials.

Anderson, D., Gilbert, P., and Burkholder, J., 2002, Harmful algal blooms and eutrophication: Nutrient sources, composition, and consequences: Estuaries, v. 25, no. 4, p. 704-726.

Bonn, B.A., 2008, Using the U.S. Geological Survey National Water Quality Laboratory LT-MDL to evaluate and analyze data: U.S. Geological Survey Open-File Report 2008-1227, $73 \mathrm{p}$.
Boyer, J.N., Kelble, C.R., Ortner, P.B., and Rudnick, D.T., 2009, Phytoplankton bloom status - Chlorophyll $a$ biomass as an indicator of water quality condition in the southern estuaries of Florida, USA: Ecological Indicators, November 2009, p. S56-S67.

Brenton, R.W., and Arnett, T.L., 1993, Methods of analysis by the U.S. Geological Survey National Water-Quality Laboratory-Determination of dissolved organic carbon by UV-promoted persulfate oxidation and infrared spectrometry: U.S. Geological Survey Open-File Report 92-480, $12 \mathrm{p}$.

Bricker, S., Longstaff, B., Dennison, W., Jones, A., Boicourt, K., Wicks, C., and Woerner, J., 2007, Effects of nutrient enrichment in the Nation's estuaries-A decade of change: Silver Spring, Md., National Oceanic and Atmospheric Administration, Coastal Ocean Program Decision Analysis Series no. 26, National Centers for Coastal Ocean Science, 322 p.

Buchman, M.F., 2008, NOAA screening quick reference tables: Seattle, Wash., Office of Response and Restoration Division, National Oceanic and Atmospheric Administration, OR\&R report, no. 08-1, 34 p., accessed February, 2, 2015, at http://response.restoration.noaa.gov/ sites/default/files/SQuiRTs.pdf.

Burkholder, J.M., 1998, Implications of harmful microalgae and heterotrophic dinoflagellates in management of sustainable marine fisheries: Ecological Applications, v. 8, no. 1, p. S37-S62.

Calandrino, E.S., and Paerl, H.W., 2011, Determining the potential for the proliferation of the harmful cyanobacterium Cylindrospermopsis raciborskii in Currituck Sound, North Carolina: Harmful Algae, v. 11, p. 1-9.

Carpenter, D., and Dubbs, L., 2012, 2012 Albemarle-Pamlico Ecosystem Assessment: Raleigh, N.C., Albemarle-Pamlico National Estuary Partnership, 263 p. [Also available at http://www.apnep.org/c/document_library/get_file?uuid= 1c126d0c-2589-40c7-ac41-125f99ad0c70\&groupId=61563.]

Chorus, I., and J. Bartram, eds., 1999, Toxic cyanobacteria in water: London, World Health Organization, 416 p.

Copeland, B.J., Hodson, R.G., Riggs, S.R., and Easley, J.E., 1983, The ecology of the Albemarle Sound, North Carolina-An estuarine profile: Washington, D.C., U.S. Fish and Wildlife Service Publication No. FWS/OBS-83/01, 68 p.

Corbett, D.R., Vance, D., Letrick, E., Mallinson, D., and Culver, S., 2007, Decadal-scale sediment dynamics and environmental change in the Albemarle Estuarine System, North Carolina: Estuarine, Coastal and Shelf Science, v. 71, p. 717-729. 
Drake, J.L., Carpenter, E.J., Cousins, M., Nelson, K.L., Guido-Zarate, A., and Loftin, K., 2010, Effects of light and nutrients on seasonal phytoplankton succession in a temperate eutrophic coastal lagoon: Hydrobiologia, v. 654, no. 1 , p. 177-192.

Dupré, D.H, Scott, J.C., Clark, M.L., Canova, M.G, and Stoker, Y.E., 2013, User's manual for the National Water Information System of the U.S. Geological SurveyWater-quality system, version 5.0: U.S. Geological Survey Open-File Report 2013-1054, 730 p.

Ezer, T., Atkinson, L.P., Corlett, W.B., and Blanco, J.L., 2013, Gulf Stream's induced sea level rise and variability along the U.S. mid-Atlantic coast: Journal of Geophysical Research Oceans, v. 118, no. 2, p. 685-697, accessed April 1, 2014, at http://dx.doi.org/10.1002/jgrc.20091.

Faires, L.M., 1993, Methods of analysis by the U.S. Geological Survey National Water Quality Laboratory-Determination of metals in water by inductively coupled plasmamass spectrometry: U.S. Geological Survey Open-File Report 92-634, 28 p.

Fishman, M.J., 1993, Methods of analysis by the U.S. Geological Survey National Water Quality Laboratory-Determination of inorganic and organic constituents in water and fluvial sediments: U.S. Geological Survey Open-File Report 93-125, 217 p.

Fishman, M.J., and Friedman, L.C., 1989, Methods for determination of inorganic substances in water and fluvial sediments: U.S. Geological Survey Techniques of Water Resources Investigations, book 5, chap. A1, 545 p.

Fitzgerald, S.A. and Gurley, L.N., 2016, Associated data for water quality and bed sediment quality in the Albemarle Sound, North Carolina, 2012-14: U.S. Geological Survey data release, https://dx.doi.org/10.5066/F7057D2V.

Fry, J., Xian, G., Jin, S., Dewitz, J., Homer, C., Yang, L., Barnes, C., Herold, N., and Wickham, J., 2011, Completion of the 2006 National Land Cover Database for the Conterminous United States: Photogrammetric Engineering and Remote-Sensing, v. 77 , no. 9 , p. $858-864$.

Garbarino, J.R., Kanagy, J.R., and Cree, M.E., 2006, Determination of elements in natural-water, biota, sediment, and soil samples using collision/reaction cell inductively coupled plasma-mass spectrometry: U.S. Geological Survey Techniques and Methods, book 5, chap. B1, 88 p.

Gibble, C.M. and Kudela, R.M., 2014, Detection of persistent microcystin toxins at the land-sea interface in Monterey Bay, California: Harmful Algae, v. 39, p. 146-153.
Giese, G.L., Wilder, H.B., and Parker, G.G., Jr., 1979, Hydrology of major estuaries and sounds of North Carolina: U.S. Geological Survey Water-Supply Paper 2221, 108 p.

Giordano, J. and Holloman, J., 2001, Taking control of nonpoint source pollution: U.S. Environmental Protection Agency Albemarle-Pamlico Estuary Program, 4 p., accessed January 5, 2016, at http://nepis.epa.gov/Exe/ZyPDF.cgi/ 200050E1.PDF?Dockey=200050E1.PDF.

Graham, J.L., 2006, Harmful algal blooms: U.S. Geological Survey Fact Sheet 2006-3147, 2 p.

Graham, J.L., Loftin, K.L., Meyer, M.T., Ziegler, A.C., 2010, Cyanotoxin mixtures and taste-and-odor compounds in cyanobacterial blooms from the Midwestern United States: Environmental Science and Technology, v. 44, p. 7361-7368.

Graham, J.L., Loftin, K.A., Ziegler, A.C., and Meyers, M.T., 2008, Cyanobacteria in lakes and reservoirs-Toxin and taste-and-odor sampling guidelines (ver. 1.0): U.S. Geological Survey Techniques of Water-Resources Investigations, book 9, chap. A7, section 7.5, accessed March 2012 at http://pubs.water.usgs.gov/twri9A/.

Hackney, C.T., Grimley, J., Posey, M., Alphin, T., and Hyland, J., 1998, Sediment contamination in North Carolina's estuaries: Wilmington, N.C., Center for Marine Science Research, University of North Carolina at Wilmington, publication no. 198, $19 \mathrm{p}$.

Hallegraeff, G.M., 1993, A review of harmful algal blooms and their apparent global increase: Phycologia, v. 32, p. 79-99.

Hambrook Berkman, J.A., and Canova, M.G., 2007, Algal biomass indicators (ver. 1.0): U.S. Geological Survey Techniques of Water-Resources Investigations, book 9 , chap. A7, section 7.4, August, accessed March 4, 2016, at http://pubs.water.usgs.gov/twri9A/.

Jenne, E.A., 1968, Controls on $\mathrm{Mn}, \mathrm{Fe}, \mathrm{Co}, \mathrm{Ni}, \mathrm{Cu}$, and $\mathrm{Zn}$ concentrations in soils and water-The significant role of hydrous Mn and Fe oxides, in Gould, R.F. (ed.), Trace inorganics in water-Advances in Chemistry Series No. 73: Washington, D.C., American Chemical Society, p. 337-387.

Jia, P., and Li, M., 2012, Circulation dynamics and salt balance in a lagoonal estuary: Journal of Geophysical Research v. 117, C01003. [Also available at http://dx.doi. org/10.1029/2011JC007124.]

Kahn, L., 1988, Determination of total organic carbon in sediment (Lloyd Kahn Method), July 27, 1988: Edison, N.J., U.S. Environmental Protection Agency, Region II, 5 p. 
Lee, R.W., and Rast, W, 1997, Light attenuation in a shallow, turbid reservoir, Lake Houston, Texas: U.S. Geological Survey Water-Resources Investigations Report 97-4064, 33 p.

Lehman, P., Boyer, G., Hall, C., Waller, S., and Gehrts, K., 2005, Distribution and toxicity of a new colonial Microcystis aeruginosa bloom in the San Francisco Bay Estuary, California: Hydrobiologia, v. 541, no. 1, p. 87-99.

Lorenz, D.L., 2015, smwrQW—R functions to support water-quality data analysis for statistical methods in water resources: Geological Survey R ArchiveNetwork, accessed January 5, 2016, at http://owi.usgs.gov/R.

Lund, J.W.G, Kipling, C., and LeCren, E.D., 1958, The inverted microscope method of estimating algal numbers and the statistical basis of estimations by counting: Hydrobiologia, v. 11, p. 143-170.

Mallin, M., McIver, M., and Johnson, V., 2006, Assessment of coastal water resources and watershed conditions at Cape Hatteras National Seashore, North Carolina: U.S. National Park Service, Water Resources Division, Natural Resource Program Center, $77 \mathrm{p}$.

McCutcheon, S.C., Martin, J.L, and Barnwell, T.O., Jr., 1993, Water Quality, chap. 11 in Maidment, D.R., ed., Handbook of Hydrology: New York, N.Y., McGraw-Hill, p. 11.3.

Miller, M.A., Kudela, R.M., Mekebri, A., Crane, D., Oates, S.C., Tinker, M.T., Staedler, M., Miller, W.A., Toy-Choutka, S., and Dominik, C., 2010, Evidence for a novel marine harmful algal bloom-Cyanotoxin (microcystin) transfer from land to sea otters: PLoS One, v. 5, no. 9, p. e12576.

Millie, D.F., Paerl, H.W., and Hurley, J.P., 1993, Microalgal pigment assessments using high performance liquid chromatography - A synopsis of organismal and ecological applications: Canadian Journal of Fisheries and Aquatic Sciences, v. 50, p. 2513-2527.

Moorman, M.C., Kolb, K.R., and Supak, S., 2014, Estuarine monitoring programs in the Albemarle Sound study area, North Carolina: U.S. Geological Survey Open-File Report 2014-1110, 38 p. [Also available at http://dx.doi.org/ 10.3133/ofr20141110.]

North Carolina Department of Environment and Natural Resources Division of Water Quality, 2003, Standard operating procedures for algae and aquatic plant sampling and analysis: accessed January 5, 2016, at http://portal. ncdenr.org/c/document_library/get_file?uuid=c2aaa6514f4d-4a9c-a402-7f695ae8601b\&groupId=38364.
North Carolina Department of Environment and Natural Resources, 2007, Surface water and wetlands standards: Raleigh, North Carolina Office of Administrative Hearings, 144 p., accessed January 5, 2016, at http://portal.ncdenr. org/c/document_library/get_file?uuid=e86a6778-ad5a411a-91dd-de52440f4a31\&groupId=38364.

North Carolina Department of Environment and Natural Resources, 2013, Intensive survey branch standard operating procedures manual—Physical and chemical monitoring, version 2.1, accessed January 5, 2016, at http://portal. ncdenr.org/c/document_library/get_file?uuid $=516 \mathrm{flb} 7 \mathrm{~b}-$ fbb6-419f-83c8-0c981b2e1f78\& groupId=38364.

North Carolina Department of Environment and Natural Resources Division of Water Resources, 2014, North Carolina nutrient criteria development plan: v. 2.0., 12 p., accessed January 5, 2016 at https://www.nclm.org/SiteCollectionDocuments/Legislative/NCDP-March-04-2014\%20 v2\%200\%20to\%20EPA.pdf.

Paerl, H.W. and Otten, T.G., 2013, Harmful cyanobacterial blooms - Causes, consequences, and controls: Microbial ecology, v. 65, no. 4, p. 995-1010.

Paerl, H.W., and Huisman, J., 2009, Climate change-A catalyst for global expansion of harmful cyanobacteria blooms: Environmental Microbiology Reports, v. 1, no. 1, p. 27-37.

Paerl, H.W., and Paul, V.J., 2012, Climate change-Links to global expansion of harmful cyanobacteria: Water Research, v. 46 , p. $1349-1363$.

Parameter-elevation Regressions on Independent Slopes Model (PRISM) Climate Group, 2012, United States average annual precipitation, 1981-2010: Corvallis, Oreg., Oregon State University, accessed November 15, 2013, at http://prism.oregonstate.edu.

Patton, C. J., and Kryskalla, J. R., 2011, Colorimetric determination of nitrate plus nitrite in water by enzymatic reduction, automated discrete analyzer methods: U.S. Geological Survey Techniques and Methods, book 5, chap. B8, 34 p.

Patton, C.J., and Truitt, E.P., 2000, Methods of analysis by the U.S. Geological Survey National Water Quality LaboratoryDetermination of ammonium plus organic nitrogen by a Kjeldahl digestion method and an automated photometric finish that includes digest cleanup by gas diffusion: U.S. Geological Survey Open-File Report 00-170, 31 p.

Riggs, S.R., and Ames, D.V., 2003, Drowning the North Carolina coast-Sea level rise and estuarine dynamics: Raleigh, N.C, N.C. Sea Grant, 152 p. 
Rounds, S.A., 2012, Alkalinity and acid neutralizing capacity (version 4.0), in National field manual for the collection of water-quality data, Wilde, F.D., and Radtke, D.B., eds., U.S. Geological Survey Techniques of Water-Resources Investigations, book 9, chap. A6, section 6.6, 45 p, accessed January 5, 2016, at http://water.usgs.gov/owq/FieldManual/ Chapter6/section6.6/.

Schemel, L.E., 2001, Simplified conversions between specific conductance and salinity units for use with data from monitoring stations: Interagency Ecological Studies Program Newsletter, v. 14, p. 17-18, accessed January 5, 2016, at http://www.iep.water.ca.gov/report/newsletter/.

Steel, Jennifer, ed., 1991, Albemarle-Pamlico Estuarine System-Technical analysis of status and trends [Status and trends report of the Albemarle-Pamlico estuary, April 1991]: Raleigh, N.C., Department of Environment, Health, and Natural Resources, Albemarle-Pamlico Estuarine System Report 91-01, accessed January 5, 2016, at http://digital. ncdcr.gov/u?/p249901 coll22,640198.

U.S. Census Bureau, 2011, 2010 Census summary file 1(North Carolina and Virginia) [machine-readable data files]: U.S. Census Bureau Web page, February 3, 2014, at http://www.census.gov/prod/cen2010/doc/sf1.pdf.

U.S. Environmental Protection Agency, 1992, Acid digestion of sediments, sludges, and soils, rev. 1, method 3050A: Cincinnati, Ohio, U.S. Environmental Protection Agency, Environmental Systems Monitoring Laboratory, Office of Research and Development, $6 \mathrm{p}$.

U.S. Environmental Protection Agency, 1993, Determination of phosphorus by semi-automated colorimetry, rev. 2.0, method 365.1: Cincinnati, Ohio, U.S. Environmental Protection Agency, Environmental Systems Monitoring Laboratory, Office of Research and Development, $17 \mathrm{p}$.

U.S. Environmental Protection Agency, 1996, Test methods for evaluating solid waste, physical/chemical methods, SW-846 (3d ed.), update IV; method 6020A, inductively coupled plasma-mass spectrometry: Washington, D.C., U.S. Environmental Protection Agency, 30 p.

U.S. Environmental Protection Agency, 1997a, In Vitro Determination of chlorophyll $a$ and pheophytin $a$ in marine and freshwater algae by fluorescence, method 445.0: Cincinnati, Ohio, U.S. Environmental Protection Agency, National Exposure Research Laboratory, Office of Research and Development, $22 \mathrm{p}$.
U.S. Environmental Protection Agency, 1997b, Volunteer stream monitoring-A methods manual: U.S. Environmental Protection Agency, EPA 841-B-97-003, 227 p.

U.S. Environmental Protection Agency, 2007, Test methods for evaluating solid waste, physical/chemical methods, SW-846 (3d ed.), update II; method 7471B, mercury in solid or semisolid waste (manual cold vapor technique), rev. 2: Washington, D.C., U.S. Environmental Protection Agency, $11 \mathrm{p}$.

U.S. Environmental Protection Agency, 2009, National water quality inventory-Report to Congress: Washington, D.C., U.S. Environmental Protection Agency, Office of Water, EPA 841 R-08-001, 43 p.

U.S. Environmental Protection Agency, 2014, National recommended water quality criteria: U.S. Environmental Protection Agency Web page, accessed February, 3, 2015, at http://water.epa.gov/scitech/swguidance/standards/criteria/ current/index.cfm.

U.S. Geological Survey, 2010, North Carolina District operating procedures and guidelines, Chapter B-Quality assurance plan for water-quality activities of the North Carolina Water Science Center: accessed March 15, 2014, at http://nc.water.usgs.gov/usgs/info/qaplan/quality.html.

U.S. Geological Survey, variously dated, National field manual for the collection of water-quality data: U.S. Geological Survey Techniques of Water-Resources Investigations, book 9, chaps. A1-A10, accessed January 5, 2016, at http://pubs.water.usgs.gov/twri9A.

Wetzel, R.G., 2001, Limnology of lake and river ecosystems: New York, Academic Press, 1006 p.

World Health Organization, 2003, Water sanitation hygieneGuidelines for safe recreational water environments, volume 1 - Coastal and fresh waters: World Health Organization Web page, accessed August 23, 2016, at http://www.who.int/water_sanitation_health/publications/ srwe $1 / \mathrm{en} /$. 



\section{Appendix 1. Quality Control Results}

Appendix 1 tables are available for download at https://doi.org/10.3133/ofr20161171.

Table 1-1a. Constituent concentrations in quality control samples collected to determine bias and variability of water samples collected in the Albemarle Sound and tributaries, 2012-14.

Table 1-1b. Summary of constituent detections in field blanks of water samples collected in the Albemarle Sound and tributaries, 2012-14.

Table 1-1c. Summary of constituent variability in field replicates of water samples collected in the Albemarle Sound and tributaries, 2012-14.

Table 1-1d. Interlaboratory assessment of constituent concentrations in field and split replicates of water samples from the Albemarle Sound and tributaries, 2012-14.

Table 1-2a. Phytoplankton taxonomy, density, and biovolume in replicate samples collected to assess variability in the Albemarle Sound and tributaries, 2012-13. Source of data: North Carolina Department of Environment and Natural Resources Division of Water Resources.

Table 1-2b. Phytoplankton density and biovolume in replicate samples collected to assess variability in the Albemarle Sound and tributaries, 2012-13. Source of data: North Carolina Department of Environment and Natural Resources Division of Water Resources.

Table 1-3a. Constituent concentrations in quality control samples collected to assess bias and variability of bed sediment samples from the Albemarle Sound and tributaries, 2012.

Table 1-3b. Recovery of elements in matrix spikes and reagent (blank) spikes for the analysis of bed sediments from the Albemarle Sound and tributaries, 2012.

Table 1-3c. Relative percent differences for elements measured in bed sediment analytical duplicates, split replicates, and field replicates collected in the Albemarle Sound and tributaries, 2012. 


\section{Appendix 2. Chemical, Biological and Physical Results for Samples Collected in the Albemarle Sound and Tributaries, 2012}

Appendix 2 tables are available for download at https://doi.org/10.3133/ofr20161171.

Table 2-1. Constituents in water samples collected in the Albemarle Sound and tributaries, 2012.

Table 2-2. Phytoplankton community cell counts and biovolumes in samples collected in the Albemarle Sound and tributaries, 2012. Source of data: North Carolina Department of Environment and Natural Resources Division of Water Resources.

Table 2-3. Water column chemical and physical profiles collected in the Albemarle Sound and tributaries, 2012.

Table 2-4. Water density and transparency data collected in the Albemarle Sound and $t$ ributaries, 2012

\section{Appendix 3. Chemical, Biological and Physical Results for Samples Collected in the Albemarle Sound and Tributaries, 2013-14}

Appendix 3 tables are available for download at https://doi.org/10.3133/ofr20161171.

Table 3-1. Constituents in water samples collected in the Albemarle Sound and tributaries, 2013-14.

Table 3-2. Phytoplankton community cell counts and biovolumes in samples collected in the Albemarle Sound and tributaries, 2013-14. Source of data: North Carolina Department of Environment and Natural Resources Division of Water Resources.

Table 3-3. Water column chemical and physical profiles collected in the Albemarle Sound and tributaries, 2013-14.

Table 3-4. Water density and transparency data collected in the Albemarle Sound and tributaries, 2013-14.

\section{Appendix 4. Constituents in Bed Sediment Samples Collected in the Albemarle Sound and Tributaries, 2012}

The appendix 4 table is available for download at https://doi.org/10.3133/ofr20161171. 
Manuscript approved September 22, 2016

Prepared by the USGS Science Publishing Network Edited by Teri Losano, Rolla PSC

Illustrations by Jeffrey Corbett, Reston PSC Layout by Caryl J. Wipperfurth, Reston PSC

For additional information regarding this publication, please contact:

Director, South Atlantic Water Science Center

U.S. Geological Survey

720 Gracern Road

Stephenson Center, Suite 129

Columbia, SC 29210

(803) 750-6100

Or visit the South Atlantic Water Science Center Web site at

http:/www.usgs.gov/water/southatlantic/ 
궁

읔

\%

웋

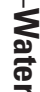

올

产

若

c)

衰

을

ㄹ.

름

흘

을

옹

을

동

ก

1

몸

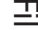

गु

음

응

$\stackrel{\overrightarrow{1}}{\vec{\Xi}}$ 